\title{
When economic and cultural interests align: the anti-immigration voter coalitions driving far right party success in Europe
}

Article

Accepted Version

Halikiopoulou, D. and Vlandas, T. (2020) When economic and cultural interests align: the anti- immigration voter coalitions driving far right party success in Europe. European Political Science Review, 12 (4). pp. 427-448. ISSN 1755-7739 doi: https://doi.org/10.1017/S175577392000020X Available at https://centaur.reading.ac.uk/89576/

It is advisable to refer to the publisher's version if you intend to cite from the work. See Guidance on citing.

To link to this article DOI: http://dx.doi.org/10.1017/S175577392000020X

Publisher: Cambridge University Press

All outputs in CentAUR are protected by Intellectual Property Rights law, including copyright law. Copyright and IPR is retained by the creators or other copyright holders. Terms and conditions for use of this material are defined in the End User Agreement.

www.reading.ac.uk/centaur 
Central Archive at the University of Reading

Reading's research outputs online 


\section{When economic and cultural interests align: the anti- immigration voter coalitions driving far right party success in Europe}

\begin{tabular}{|r|l|}
\hline Journal: & European Political Science Review \\
\hline Manuscript ID & EPSR-2019-0090.R2 \\
\hline Keyworcript Type: & Research Article \\
\hline Subject Category: & far right parties, immigration, European Social Survey, Economy, Culture \\
\hline Abstract: & $\begin{array}{l}\text { Parties (and party systems, elections, voting, referenda) } \\
\text { This article contests the view that the strong positive correlation between } \\
\text { anti-immigration attitudes and far right party success constitutes } \\
\text { evidence in support of the cultural grievance thesis and against the } \\
\text { economic grievance thesis. We argue that far right party success } \\
\text { depends on the ability to mobilise a coalition of interests between their } \\
\text { core supporters, i.e. voters with cultural grievances over immigration } \\
\text { immigration. Using individual level data from } 8 \text { rounds of the European } \\
\text { Social Survey (ESS), our empirical analysis shows that while cultural } \\
\text { concerns over immigration are a stronger predictor of far right party } \\
\text { support, those who dislike the impact of immigration on the economy are } \\
\text { important to the far right in numerical terms. Taken together, our } \\
\text { findings suggest that economic grievances over immigration remain } \\
\text { pivotal within the context of the transnational cleavage. }\end{array}$ \\
\hline
\end{tabular}

\section{SCHOLARONE Manuscripts}




\section{When economic and cultural interests align: the anti-immigration voter coalitions driving far right party success in Europe}

Far right party success depends largely on mobilising grievances over immigration (Golder 2003; Ivarsflaten 2008; Rydgren 2008; Rooduijn et al 2017). This is particularly relevant within the context of an emerging transnational cleavage at the core of which lies a value conflict between those who support and those who reject multi-culturalism, cosmopolitanism and globalization (Hooghe and Marks 2017). Theoretically, the importance of cultural values in shaping voting behaviour within the context of this cleavage, and empirically the strong association of cultural concerns over immigration and far right party support at the individual level have led to an emerging consensus in the literature that the increasing success of far right parties may be best understood as a 'cultural backlash' (Inglehart and Norris 2016), i.e. a reaction to the perceived cultural threats posed by immigration.

Scholars recognise that there are theoretical reasons to expect the material aspects of immigration scepticism to also matter even within the context of a transnational cleavage. However, most empirical studies tend to support the cultural explanation. In terms of antiimmigration attitudes, findings regarding the labour market competition hypothesis are highly contested (Malhotra et. al 2013; Chandler and Tsai 2001; Citrin and Sides 2008; Sniderman et al 2004; Hainmueller and Hopkins 2014). In terms of far right party support, economic explanations are often dismissed or understood as secondary (Lubbers and Güveli 2007; Lucassen and Lubbers 2012; Inglehart and Norris 2016) given the greater predictive power of cultural concerns over immigration at the individual level.

This article contests the view that immigration is a predominantly cultural issue and that the strong positive correlation between anti-immigration attitudes and far right party success 
necessarily and by default constitutes evidence in support of the cultural grievance thesis. We suggest that insufficient attention has been paid both to the predictive power of socio-tropic economic concerns over immigration, and to the important distinction between galvanising a core constituency on the one hand, and mobilizing more broadly beyond this core constituency on the other. We posit and test a twofold argument using data on immigration concerns and the far right vote from 8 rounds of the European Social Survey (ESS) across 19 countries.

Our findings from multilevel mixed effects logistic regressions, cross-tabulations, scatter plots and simulations indicate that, first, both cultural and economic concerns over immigration increase the likelihood of voting for a far right party. Second, while cultural concerns are a stronger predictor of far right party voting behaviour in a statistical sense, this does not automatically mean that they matter more for far right party success in substantive terms. What determines far right party success is the ability to mobilise a coalition of interests between core voters, i.e. those primarily concerned with the cultural impact of immigration, and as large a subset as possible of peripheral voters, i.e. the often numerically larger group of voters who are primarily concerned with the economic impact of immigration, as well as those who do not have concerns about immigration. This coalition is necessary for far right parties to extend their mobilisation capacity beyond their core support base and thus make significant electoral gains.

This article proceeds as follows. First, we review the literature on immigration-related grievances and far right party support. Second, we present our argument, focusing on why mobilising a coalition of voters with different types of immigration-related concerns is key to understanding far right party support. Third, we discuss our data and methods and proceed to test our argument empirically. The article concludes with some of the broader implications of our argument and directions for future research. 


\section{Immigration and 'the cultural backlash'}

The growing popularity of the far right is often linked to voters' concerns over immigration (Rydgren 2008; Ivarsflaten 2008; Arzheimer 2009; Hainmueller and Hopkins 2014; Rooduijn et al 2017). Studies find that immigration has a positive effect on far right parties, often irrespective of other factors (Golder 2003). Voters are either affected by actual immigrant numbers, or by negative perceptions about immigrants, or both (Stockemer 2016). Far right parties, which 'own' the immigration issue (Van der Brug and Fennema 2007; Van Spanje 2010) and share a common emphasis on nationalism (Vasilopoulou and Halikiopoulou 2015) or nativism (Mudde 2007), sovereignty and policies that promote a 'national preference' are well placed to exploit immigration-related grievances and generate greater demand.

The question of immigration is particularly relevant within the context of an emerging transnational cleavage whose focal point is 'the defence of national political, social and economic ways of life against external actors' (Hooghe and Marks 2017: 2). The increasing salience of the immigration issue may be partly understood by this development, which has altered in-group and out-group dynamics. The transnational cleavage divides voters who hold cosmopolitan values from those who hold nationalist ones and can be best understood as a value conflict between voters who support and voters who reject multi-culturalism, globalization, as well as social and ethnic diversity. It is the result of rapid and profound value change in post-industrial societies (Inglehart and Norris 2016).

Because at the core of the transnational cleavage is a cultural - or value - conflict, scholars emphasize the importance of the cultural dimension of competition with immigrants in driving far right party success. The main proposition of the cultural grievance thesis is the perceived incompatibility between native and immigrant behavioural norms and cultural values (Golder 2016: 485). In other words, the argument here is that what drives far right 
party support is a fear that immigrants erode the national culture and traditional ways of life, thus threatening the value consensus upon which social norms are based. This cultural threat exacerbates prejudices against immigrants, and prompts voters to opt for parties whose main agendas are centred on limiting immigration. According to this view, far right party support may be best understood as 'a cultural backlash': i.e. a reaction to value change by those who reject universalistic values and place emphasis on national identity and fear the erosion of their cultural values (Inglehart and Norris 2016).

A large body of empirical research finds support for the cultural grievance hypothesis at the individual level (Inglehart and Norris 2016; Lucassen and Lubbers 2012; Lubbers and Güveli 2007). This complements findings that pervasive cultural concerns are an underlying source of opposition to immigration and that culture is more important than economic advantage in evoking anti-immigration sentiments (e.g. Chandler and Tsai 2001; Citrin and Sides 2008; Sniderman et al 2004; Hainmueller and Hopkins 2014).

Evidence includes post-material voting trends determined by factors such as age and education, the endorsement of authoritarian values, mistrust in political institutions and general resentment towards out-groups (Inglehart and Norris 2016). In addition, scholars emphasise the association between cultural concerns, nationalistic attitudes (Lubbers and Coenders 2017), euroscepticism (Van Elsas et. al 2016) and class (Oesch (2008). As part of this broader trend towards cultural-oriented explanations of far right party support, immigration scepticism tends to often be identified as a cultural issue (Inglehart and Norris 2016; Kaufmann 2017). 


\section{Labour market competition and economic grievances}

Immigration, however, is a multi-faceted issue (Mudde 2012; Lucassen Lubbers 2012; Malhotra et al 2013; Rydgren 2008). Indeed more recent scholarship stresses that the culture versus economy debate is a false dichotomy (e.g. Gidron and Hall 2017; Adler and Ansell 2020), and that both dimensions matter, often shaping each other (Burns and Gimpel 2000). There are reasons to expect that competition with immigrants will likely be shaped not only by cultural but also by material interests. Indeed, the Labour Market Competition hypothesis suggests that prejudices against immigrants have objective economic foundations (Polavieja 2016; Hellwig and Kweon 2016; Dancygier and Donnelly 2013; Malhotra et. al 2013; Mayda 2006; Scheve and Slaughter 2001). Concerns might be either ego-tropic or socio-tropic, meaning that either those pessimistic about their personal economic situation and/or those pessimistic about the impact of immigration on the nation's economy as a whole, are more likely to have negative attitudes towards some migrant/ minority groups (Hainmueller and Hopkins 2014; Burns and Gimpel 2000).

We might expect this to hold even in the context of the new transnational cleavage mainly prevalent in post-industrial societies. The decline of traditional cleavages does not necessarily imply that social and economic divisions are politically irrelevant, as new cleavages are 'strongly shaped by the political legacy of traditional cleavages' (Kriesi 1998: 165-167). While indeed comprehensive welfare states protect minimal standards of living (Inglehart and Norris 2016; Vlandas and Halikiopoulou 2018), relative deprivation and inequality still affect voters (Adler and Ansell 2020; Colantone and Stanig 2018; Engler and Weisstanner 2020), and position in the labour market continues to have an impact on voting behaviour (Swank and Betz 2003; Swank and Betz 2018; Rovny and Rovny 2017; Kitchelt 2018). 
A close association between labour-market competition and negative views on immigration is more likely when a labour market threat is present (Malhotra et. al 2013: 392). Social groups that have a higher degree of exposure to labour-market competition are more likely to have an interest in limiting immigration because 'an increase in the supply of immigrant workers is likely to lower their wages and/or to increase job insecurity' (Polavieja 2016:396). These may include - but are not confined to- the lower social strata. Which social group will be affected depends on country, individual occupational source, employment sector, and skill level (Dancygier and Donnelly 2013). Skilled individuals are more likely to favour immigration in countries where natives are more skilled than immigrants (and oppose it otherwise), 'because in this case immigration reduces the supply of skilled relative to unskilled labour and raises the skilled wage' (Mayda 2006:510). Individuals employed in growing sectors are more likely to support immigration than those employed in shrinking sectors (Dancygier and Donnelly 2013). Less-skilled workers are more likely to prefer limiting immigrant inflows (Scheve and Slaughter 2001). There is also a policy effect as national protection policies may reduce hostility towards immigration (Artiles and Meardi 2014).

All this suggests we should treat immigration as a complex issue, and expect reasons other than xenophobic or racist attitudes including economic grievances (Rydgren 2008) to affect people's attitudes towards immigration and the way they vote. To account for this, research has increasingly distinguished between the different sets of threats- mainly cultural and economic- posed by immigration, and their impact on anti-immigration attitudes (Sniderman et. al 2004; Malhotra et. al 2013) and far right party support (Lucassen and Lubbers 2012; Sniderman et al 2004; Rydgren 2008).

The majority of studies, however, that consider, and juxtapose, both the economic and cultural dimensions of anti-immigration attitudes and far right party support find greater 
support for the cultural grievance thesis and tend to agree that, although both dimensions matter, the economy matters much less than culture. These conclusions are based predominantly- but not exclusively- on the strong predictive power of cultural variables at the individual level (Lubbers and Güveli 2007; Lucassen and Lubbers 2012; for a review of studies explaining attitudes on immigration see Hainmueller and Hopkins 2014).

\section{Why mobilising an anti-immigrant voter coalition is key to understanding far right party success}

\section{Immigration is not just a cultural issue}

This article contests the view that immigration is predominantly a cultural issue and that the stronger predictive power of cultural concerns over immigration necessarily implies that culture is always more important than the economy in driving far right party success. We argue instead that both cultural and economic concerns matter, albeit in different ways. Our argument responds to recent calls in the literature to refine and better explain the economic anxiety thesis instead of disregarding it (Mudde and Rovira Kaltwasser 2018). We do so by paying more attention to voters' socio-tropic economic concerns over immigration and to the size and coalition potential of voter groups with both cultural and economic concerns over immigration.

Specifically, our argument enfolds into two separate claims. First, while cultural concerns over immigration are indeed a stronger predictor of voting for the far right than economic concerns, the latter also have predictive power that is not negligible. This is particularly true of socio-tropic concerns: people's views about the impact of immigration on the economy motivate them to express opposition to immigration on economic grounds. While, however, scholars agree that socio-tropic drivers of anti-immigration attitudes 'can be economic as 
well' (Hainmueller and Hopkins 2014:230) and that pessimism about the national economy is likely to predict restrictive immigration attitudes (Citrin et al 1997; Kinder \& Kiewiet 1981; Hainmueller and Hopkins 2014), this is often de-emphasised and under-theorized in cultural arguments about far right party support.

Second, we make the case that in order to understand a party's electoral success we need to consider not just the predictive power of certain attitudes but also the ways in which they are incorporated into politics. This points to the crucial distinction between receiving support from a core constituency and being able to mobilise more broadly. A party is more likely to have a large electoral potential if 'a substantial proportion of the voters agree with its political program' (Van der Brug et al 2005: 563). It must therefore broaden its support beyond its secure voting base in order to be electorally successful (e.g. Tilley and Evans 2017). This entails mobilizing a coalition of interests between different social classes or groups with different preferences. In sum, the size of, and coalition potential between, groups play a key role in explaining successful electoral performance.

\section{Core and peripheral far right voters}

Far right parties share a common emphasis on nationalism, or nativism, in their programmatic agendas (Hainsworth 2008; Mudde 2007). They compete along the national identity axis (Ellinas 2013) and centre their political programmes on a purported conflict between ingroups and out-groups, postulating that the in-group must in all circumstances be prioritised at the expense of the out-group. Their signature is to propose nationalist solutions to all socioeconomic problems (Vasilopoulou and Halikiopoulou 2015).

The broad umbrella of voters with nationalist concerns (Lubbers and Coenders 2017) is a key far right party target group because these voters are more likely to identify with far right positions and the issues they deem salient. Immigration is central: far right parties have 
ownership of the immigration issue (e.g. Van Spagne 2010), because the latter speaks to the debate about entitlement to national membership, and as such is directly linked to nationalism (Halikiopoulou and Vasilopoulou 2018). Voters with nationalist concerns relating to immigration, therefore, could significantly increase the electoral fortunes of far right parties given the rise in the salience of this issue within the context of the transnational cleavage (Hooghe and Marks 2017).

Nationalism, understood as the 'attainment and maintenance of autonomy, unity and identity of a nation' (Breuilly 2005: 16-17), however, is multi-dimensional. Its different components include the ethnic, cultural, territorial and economic (Halikiopoulou et al 2012). Opposition to immigration can be linked to one, all, or some- in the form of a combination- of these components. Voters are likely to have different party preferences depending on the source of their grievance and the extent to which they identify with the proposed party's nationalist platform. This suggests a distinction between core and peripheral voters, which we elaborate on below.

Traditionally far right parties have been associated with ethnic nationalism and xenophobia (Halikiopoulou et al 2012; Rydgren 2008). Core far right voters (we term these voters 'the culturalists') are more likely to be primarily concerned with the cultural threat posed by immigration, and to identify with all elements of nationalism and, by extension, the entire far right party platform. Because their support of the far right is principled, and more specifically linked to a principled form of xenophobia (Rydgren 2008), they see far right parties as their natural home. Peripheral voters, on the other hand, identify only partially with this platform. As such, their support is more contingent. This includes groups primarily concerned with the economic impact of immigration (we term these voters 'the materialists'). These voters are likely to support the prioritization of the in-group on economic grounds but do not necessarily identify with the other nationalist elements of far right agendas, including the ethnic and 
cultural. Because their concerns are related to a weaker form of immigration scepticism (Rydgren 2008) and their out-group attitudes are not principled, they may be catered for by a number of other parties and their affinity with the far right is less strong.

The implication of this distinction between core and peripheral voter groups is as follows. While the culturalists are core supporters and hence more likely to vote for the far right, it does not follow that they are automatically more important. To be successful, far right parties can, and often do, draw on a subset of an often larger peripheral electoral group composed of materialists, whose preferences may be more likely to include other parties addressing their economic concerns about immigration. Using European Social Survey data of 19 European countries (see data section for more details), Figure 1 compares the distribution of economic and cultural concerns over immigration. It is clear from this figure that there are more respondents with economic concerns than with cultural concerns.

\section{--- Figure 1 about here ---}

The ability to mobilise as large a subset of materialists determines far right party success. Sniderman et al's (2004:36) distinction between galvanising a core constituency and mobilizing more broadly is crucial for our point: "politically [it] makes all the difference as it enlarges the portion of the public in support of these parties and/or the policies they advocate'. This mobilisation can be brought about by situational triggers, which exacerbate voters' socio-tropic economic concerns over immigration. This group of voters - the 'materialists' - may not be the core constituency of far right parties, but it is still highly likely to support far right parties because, as we have argued above, economic concerns over immigration may matter even if they are weaker predictors of voting for the far right than cultural concerns. As a result, it is precisely materialist voters (and/ or voters without 
immigration concerns) who need to be mobilised by far right parties and in many ways determine their broader electoral success of such parties.

Why might we expect some far right parties to be better able to mobilise materialists more than others? Supply-side literature has emphasised the shift from predominantly ethnic (or nativist) nationalist narratives, which draw on ascriptive criteria, to more civic narratives, which draw on ideological rationalisations of national belonging (Halikiopoulou et al 2013). This shift in turn allows these parties to extend their appeal to a broad range of immigration sceptics (Rydgren 2008). Part of this changing narrative is an explicit move away from market liberal positions (Kitschelt and McGann 1995) to the adoption of welfare chauvinism (De Lange 2007; Ivaldi 2015; De Koster et al 2013; Afonso and Papadopoulos 2015; Afonso and Rennwald 2017), which draws on economic nationalism, thus speaking directly to those voters with material insecurities feeding concerns over immigration.

\section{The importance of group size}

Our point regarding the importance of the size of a given group is best illustrated with a simple hypothetical example, displayed graphically in figure 2. Suppose the electorate is composed of 110 voters and all are concerned about immigration, but 10 feel culturally insecure about immigration (the culturalists), while the remaining 100 feel economically insecure about immigration (the materialists). Suppose further that in the last election, 5 out 10 people in the culturalist camp voted for the far right so that they have a $50 \%$ probability of voting for the far right. By contrast in the materialist camp, 10 out of 100 voted for the far right so that they have a $10 \%$ probability of voting for the far right. Thus, in this example, a culturalist is ceteris paribus five times as likely as a materialist to vote for the far right, yet the materialists are much more important to the success of far right parties than the culturalists. 
The materialist group determines far right party success because of its numerical majority despite the fact that individual concerns about immigration's cultural impact have a stronger effect on individual far right party support than do concerns about its economic impact. Therefore, while it may well be that the core of support for far right parties objects to immigration on cultural grounds, it is the more economically oriented concerns that are especially influential in allowing these parties to expand beyond that core - and indeed those without immigration concerns. In other words, in order to increase their electoral chances, far right parties must mobilise immigration-related grievances beyond culture. In appendix 4, we demonstrate using a larger sample of hypothetical data that it is indeed possible for the characteristic associated with a much smaller group of far right supporters to have a larger effect on far right voting.

--- Figure 2 about here ---

The point of this hypothetical example is to show that stronger predictive power in a statistical sense does not necessarily equate to substantive importance in a theoretical and empirical sense. This explains why we cannot infer from the stronger predictive power of individual cultural concerns over voting for far right parties that they necessarily matter more for far right party success at the national level in substantive terms. The assumption that the predictive power of a variable at the individual level equals substantive importance at the national level suffers from an atomistic- or individualistic- fallacy, which consists of "formulating inferences at a higher level based on analyses performed at a lower level" (Hox, 2010: 3) ${ }^{1}$. Generalising from the individual to the aggregate level is inappropriate because 'relationships among variables that hold at one level do not necessarily hold at another level of the hierarchy' (Croon and Veldhoven 2007: 45). The attempt to make such inferences

\footnotetext{
${ }^{1}$ Drawing national level conclusion from individual level results is potentially as problematic as inferring individual level dynamics from national level results (i.e. an ecological fallacy), but has been so far neglected in the literature on far right voting.
} 
overlooks the composition dimension- or in other words the size of the group that shares this particular concern and how widespread this concern actually is among the electorate. Thus, while some variables may be stronger predictors, this does not automatically tell us what matters more in the sense of accounting for this party's electoral success.

\section{Research design}

\section{Data}

In order to examine how and to what extent far right party success depends on mobilising grievances over the cultural and economic impact of immigration, we combine eight waves ${ }^{2}$ of the European Social Survey (ESS), which has been used by previous research on both immigration attitudes and far right support (see e.g. Citrin and Sides 2008; Ivarsflaten 2008; Rydgren 2008; Lucassen and Lubbers 2012; Inglehart and Norris 2016).

We adopt the terminology 'far right' in accordance to Lucassen and Lubbers (2012), and examine all parties that propose nationalist solutions to a variety of socio-economic problems (Vasilopoulou and Halikiopoulou 2015), compete along the national identity axis (Ellinas 2011) and 'own' the immigration issue (Van Spagne 2010; Lucassen and Lubbers 2012). Our analysis includes 31 parties in 19 European countries. In each country-wave, respondents were asked which political party they voted for in the last national election. Our dependent variable measures far right party support and is binary: it is coded 1 if the respondent voted for a far right party and 0 if the respondent voted for another party. The countries, parties, ESS round in which they included, and relevant sources corroborating our classification are listed in appendix 1.

\footnotetext{
2 The data was accessed in November 2019 and consists of the following 8 waves: 2002, 2004, 2006, 2008, 2010, 2012, 2014, 2016.
} 
Our independent variables include questions that ask respondents whether they think their country's cultural life is undermined $(0)$ or enriched (10) by immigrants (henceforth 'cultural concerns about immigration') and whether they think immigration is bad (0) or good (10) for their country's economy (henceforth 'economic concerns about immigration'). In each case, we reverse the scale so that higher values indicate greater concern.

These two variables are partly correlated (0.62) and as such, one may contend they should be treated as a single variable. However, recent studies have treated the two as separate, assessing the extent to which each type of threat affects attitudes and voters' propensity to vote for the far right and showing that the two sets of threats 'independently affect prejudice' (Lucassen and Lubbers 2012: 548; see also Sniderman et al 2004). For instance, Lucassen and Lubbers (2012) use data from the $1^{\text {st }}$ round of the ESS round to juxtapose cultural and economic threats over immigration and far right party support in 11 European countries. Similarly, using data from the $1^{\text {st }}$ round of the ESS, but focusing on 6 European countries, Rydgren (2008: 738) also differentiates between racists, xenophobes and immigration sceptics arguing these dimensions 'overlap asymmetrically'. In addition, Lubbers and Güveli (2007) juxtapose cultural ethnic and economic concerns over immigration and their impact on voting for LPF using the Dutch sample of the ESS. Finally, also focusing on the Netherlands and using a series of experiments, Sniderman et al (2004: 35) contrast the importance of considerations of national identity and economic advantage in 'evoking exclusionary reactions to immigration minorities'. These studies point to the importance of conducting further research that distinguishes cultural from economic threats (Lucassen and Lubbers 2012: 576) by using larger samples and including more cases. Following this literature, we also treat the two variables as separate but also run a variety of tests paying close attention to the extent to which they differ and overlap. 
Our controls include age, gender, education (in years), occupation ${ }^{3}$ and source of income . $^{4}$ We also control for level of income. While waves 4 to 8 use the standard 10 -income decile classification, the first three waves of the ESS rely on a 12-category variable. We therefore create two separate variables: the first is coded 1 if the respondent is in the bottom $50 \%$ of categories (bottom 5 deciles in one case and bottom 6 categories in second case) and 0 otherwise; the second variable is coded 1 if the respondent is in the bottom $10 \%$ for the decile variable and in bottom 2 categories for the 12 categories variable. Finally, we control for partisanship, Euroscepticism and trust in institutions. An 11-point left-right self-placement scale is used to capture the ideological location of the respondents. To account for Euroscepticism we include a trust in European parliament variable (0-complete trust at all to 10-no trust at all trust). There are several variables asking respondents about their levels of trust. We use 'trust in national parliament' but show results are the same if we use different forms of trust such as trust in legal system, politicians and political parties, and we have also tried alternative measures of trust (see table A3.2 in appendix). All summary statistics are shown in table A2.1 in appendix.

\section{Method}

Our methodological approach is as follows. First, our aim is to investigate whether and how different immigration concerns affect the probability of voting for the far right. Using multilevel mixed-effects logistic regressions, we examine whether cultural and economic individual concerns about immigration have an effect on voting for the far right and which of

\footnotetext{
3 The ESS allows us to capture the following occupations: manager, professional, technician, clerical, service, agriculture, craft, operator, and elementary

${ }^{4}$ We capture (1) Wages or salaries; (2) Income from self-employment (excluding farming); (3) Income from farming; (4) Pensions; (5) Unemployment/redundancy benefit; (6) Any other social benefits or grants; (7) Income from investments, savings, etc; and (8) Income from other sources.
} 
these two concerns has stronger predictive power. The standard errors are robust and clustered by country-wave.

Second, we need to ascertain the share of respondents that have each type of concern and vote for far right parties. This speaks to our point about the size of voter groups with different concerns over immigration. A series of tabulations reveals that there are more individuals with economic than with cultural concerns over immigration and that those who are concerned about the impact of immigration on the economy are more important to the far right in numerical terms than those concerned with its impact on culture.

Third, we examine the implications of our argument at the national level. We focus on the cross-national variation in far right party support by plotting the share of materialists and culturalists that vote for the far right against the overall percentage of the far right electorate. More formally, we also test whether the impact of being a culturalist or a materialist on the probability of voting for the far right at the individual level has a bearing on far right party support at the national level. In a first step, we run a series of logistic regression analyses for each country-wave in our sample 5 . In a second step, we extract the country-wave coefficients for the two variables capturing economic and cultural concerns over immigration, respectively, and we then regress national level share of far right party support as the dependent variable on these two coefficients as two independent variables. This allows us to assess whether the individual level predictive power of concerns correlates with national level success.

Finally, we run a series of simple simulations to evaluate the extent to which artificially varying the distribution of economic and cultural concerns in a given country would result in a different electoral score for the far right. We run a series of logistic regression analyses for

\footnotetext{
${ }^{5}$ Each logistic regression controls for the same variables as our multi-level analysis carried out above.
} 
each country in our sample. Using the coefficients from these regressions, we calculate individual predicted probabilities for different distributions of economic and cultural concerns: everyone scores 0 , everyone scores the true distribution of concerns, and everyone scores 10 . We then predict country level far right party support for all possible combinations of these three levels of economic and cultural concerns (i.e. $3 \times 3=9$ scenarios).

\section{Results: the impact of immigration concerns on far right party success in Europe}

The predictive power of economic and cultural concerns

Table 1 reports the coefficients for our key independent variables ${ }^{6}$. In column 1 , we can see that both economic and cultural concerns have a positive and statistically significant association with the probability of voting for the far right. Cultural concerns seem to have stronger predictive power, as we will confirm later by calculating predicted probabilities for different scenarios in a second step. There is a positive and significant association between being male and voting for the far right, while older individuals appear less likely to support the far right. By contrast, being in the bottom of the income distribution has no statistically significant association (column 1) ${ }^{7}$. The subsequent columns include additional controls stepwise and our results concerning the impact of economic and cultural concerns are stable. Having higher education is negatively associated with support for the far right. These results are consistent with literature that identifies the typical far right voter as a young male, with a low level of education (Lubbers \& Scheepers 2002, Arzheimer 2009, Lucassen \& Lubbers 2012; Golder 2016).

\footnotetext{
${ }^{6}$ The average marginal effects of economic and cultural concerns over immigration are show in Table A3.1b in appendix.

${ }^{7}$ Note however that in column 8 when we use a different proxy for having low income we find that the coefficient becomes statistically significant and positive.
} 
We find mixed evidence regarding source of income. Being self-employed and receiving a pension are both negatively associated with voting for the far right. The statistical significance of receiving 'other (non-unemployment/non-pension benefits) social benefits' is not stable across specifications. We also find a positive and significant association between being unemployed and voting for the far right in all specifications. In terms of occupation, the highly skilled professionals have the strongest negative association with the probability of o voting for the far right, while workers in skill-specific craft occupations and low skilled workers employed as operators (both occupations capturing core parts of the manufacturing sector) are most likely to vote for far right. Right-leaning individuals are associated with higher support for the far right, while trust in national and European institutions is negatively associated with support for the far right (columns 7 and 8).

In order to assess which variable has the largest effect on the probability of voting for the far right, we calculate the difference in the predicted probability when taking the maximum versus the minimum value of each independent variable (see column 9, table 1). The largest effects on the predicted probabilities can be observed for the following variables: left-right scale; cultural concerns over immigration; economic concerns over immigration; education and trust. Next, with respect to occupations, craft, operator and service occupations have the highest effect on predicted probabilities. Being male, unemployed, or a clerical worker also have a sizeable effect (above 1 percentage point higher predicted probabilities). By contrast, the magnitude of the effect of different income sources such as pensions or self-employment is lower (under 1 percentage difference) and similarly for certain occupations (agriculture and professionals).

--- Table 1 about here-- 
We carry out a number of robustness checks. The results are the same for economic and cultural concerns over immigration when including the borderline Law and Justice (PiS) in the analysis (see appendix 5). We also reproduce our results with alternative measures of trust (table A3.2 in appendix). Next, we change the operationalisation of our key independent variables. We rerun the results of column 8 in table 1 using a binary version of our initial variables measuring cultural and economic concerns over immigration. Our binary economic concerns over immigration variable is coded 1 if the respondents choose a response above 5 to the question of whether immigration is good or bad for the country's economy, and 0 otherwise. Similarly, the binary cultural concerns over immigration variable is coded 1 if respondents choose a response above 5 to the question of whether immigration is good or bad for the country's culture, and 0 otherwise.

Cross-tabulating these two variables reveals that $55.6 \%$ of respondents have neither economic nor cultural concerns, $8.2 \%$ have cultural but not economic concerns, $15.2 \%$ have economic but not cultural concerns, and 20\% have both types of concerns over immigration (table A3.6 in appendix). The results in table A3.3.a in the appendix confirm that being a culturalist has greater predictive power than being in a materialist. To address potential criticisms about treating economic and cultural concerns as two separate variables we add an interaction term and the results are the same (see table A3.4 in the appendix). We also reproduce these results using binned variables for economic and cultural concerns: the stronger effect of cultural concerns over immigration is confirmed using this different operationalization (see table A3.5.b).

Using the same model as in column 8 in table 1, we can predict the probability of voting for the far right for individuals with different levels of economic and cultural concerns over immigration. As figure 3 shows, having cultural concerns has a stronger effect on the 
predicted probability of voting for the far right, but economic concerns also matter, especially among those with cultural concerns. Even among those with no cultural concerns, an individual with strong economic concerns would be more than twice as likely as an individual with no economic concerns at all to vote for the far right. These results indicate that overall cultural concerns over immigration are a stronger predictor of far right party support, but that economic concerns also matter.

We check the robustness of these results as well. First, as above, the findings are similar when including PiS in the analysis (see figure A5.1 in appendix). Second, we reproduce figure 3 while including an interaction term between economic and cultural concerns over immigration (see Figure A3.2 in appendix). The results are similar but the impact of economic concerns is now stronger among those with very low cultural concerns and weaker among those with very high cultural concerns. Third, we recalculate and plot the predicted probability using the two binary versions of cultural and economic concerns and then using the two 'strict' version of concerns discussed above: both cultural and economic concerns increase the likelihood of supporting a far right party (figures A3.3 and A3.4 in appendix). Overall, our findings suggest that both economic and cultural concerns have a statistically significant positive effect on the probability of voting for the far right, while the predictive power of cultural concerns is stronger.

\section{--- Figure 3 about here---}

\section{Extending support beyond the core far right constituency}

Recall figure 1, which displays the tabulations for economic and cultural concerns over immigration. We can see that at every point of the scale the share of those with economic concerns is greater than for those with cultural concerns. If we use a cut-off point of 5 for 
each type of concern, we can observe that nearly $57 \%$ of our sample scores under the cut-off point for both economic and cultural concerns; $8.2 \%$ are culturalists but not materialists, $15 \%$ are materialists but not culturalists and nearly $20 \%$ are above this cut-off point for both economic and cultural concerns (table A3.6 in appendix). This indicates that the primacy of culture as an explanation of anti-immigration attitudes is not as straightforward as suggested in the literature: even if the predictive power of cultural concerns is greater, there are more people with economic concerns than people with cultural concerns about immigration. In other words, while culturalists are more likely to vote for the far right, materialists are a numerically larger group.

Figure 4 offers a graphical illustration of the number of voters and non-voters for the far right for different levels of economic and cultural concerns. While the share of far right voters for those with cultural concerns is higher (top panel) than the share of these voters among those with economic concerns (bottom panel), there are many more people with economic concerns and as a result they remain more important to the far right. For instance, in this example there are 4,182 respondents with economic concerns above 5 who voted for far right compared to 3,925 respondents with cultural concerns above 5 who voted for far right (table A2.3 in appendix).

In figure 5 we plot the distribution of respondents with different types of concerns (just economic, just cultural, both and neither types of concerns) for each country's far right electorate. In a range of countries, those with pure economic concerns are more numerous among the far right electorate than those with pure cultural concerns. In addition, those with pure economic concerns when added to those without any types of concerns are more numerous in many countries than those with both economic and cultural concerns (and the latter picture is even starker if a higher cut-off point of 7 is used to identify concerns - see Figure A2.9 in appendix). Consequently, if we remove respondents with pure economic 
concerns from far right electorate, this results in many countries in a much lower electoral score than if we remove those with pure cultural concerns (see figure A2.10 in appendix).

\section{--- Figures 4 and 5 about here---}

\section{Cross-national variation in far right party support and immigration concerns}

Thus far, we have argued that both economic and cultural concerns matter for far right party success: having these concerns increases the probability of voting for the far right. In addition, these concerns matter in different ways. While cultural concerns have a stronger predictive power, there are often more people with economic concerns and this group is therefore important for far right party success in numerical terms.

What do these results mean for the cross-national variation in far right party support? If economic concerns were of no or of secondary importance to far right party success, then the share of materialists who vote for the far right should have little bearing on the total share of the far right vote at the national level. However, the evidence is not consistent with this expectation. The bottom panel of Figure 6 plots the country average percentage of far right party votes against the percentage of respondents with economic concerns. The fit appears strong: countries with high average far right party support tend to exhibit substantial support for those parties from materialists (the correlation is above 0.9 with $\mathrm{p}$-value $<0.001$ and $\mathrm{R}$ squared of 0.931 ). If we plot instead the country average percentage of far right party votes against the percentage of respondents with cultural concerns, a similar picture and the correlation remains strong but the R-squared is a lower 0.870 (see top panel of figure 6).

\section{---Figure 6 about here---}

Next, we investigate the extent to which the strong predictive power of cultural concerns over immigration at the individual level necessarily translates into higher far right party support at 
the national level. In other words, is it the case that countries where culturalists are very likely to vote for the far right have particularly high levels of far right party support? To answer this question we create a new dataset with three variables. The dependent variable is the average far right party vote in a given country-wave. Two independent variables capture the predictive power of each type of concern - cultural and economic - over immigration on voting for the far right at the individual level. These two variables are created by extracting the coefficients from a series of logistic regressions for each and every country-wave in our original sample.

The results suggest that there is no statistically significant correlation between the predictive power of cultural concerns on the individual probability of voting for a far right party in a given country-wave and national level far right party votes in that country-wave. By contrast, the predictive power of economic concerns on the individual probability of voting for a far right party in a given country-wave is significantly and positively correlated with the countrywave average far right party vote (see table 2). In sum, countries where culturalists are highly likely to vote for the far right, as captured by higher coefficients, do not necessarily exhibit high far right party support. This constitutes further evidence that the predictive power of individual level cultural concerns is not enough to explain a party's electoral success.

\section{---Table 2 about here---}

\section{Simulations}

Finally, using a series of country level logistic regressions we simulate different scenarios to assess precisely how the predicted country level far right party support varies depending on the distribution of respondents with 0 , actual, or 10 on the scale of economic versus cultural concerns over immigration. This is shown in Figure 7 (for country specific graphs see figure A4.1 in appendix). To illustrate, the square sign for Austria indicates that predicted support is highest when both economic and cultural concerns are set at 10 for every single respondent in 
that country, and lowest when these are set at 0 . The key piece of information here is to compare the predicted support for the actual distribution of both types of concerns to what happens to this prediction when either cultural or economic concerns are set at their maximum versus minimum values.

Setting economic concerns for everyone at 0 , results in lower predicted national support than doing the same for cultural concerns in four countries: Sweden, Norway, the Netherlands and Bulgaria. In a number of countries, setting cultural concerns at 0 result in lower predicted national support than doing the same for economic concerns (but only by less than $1 \%$ ): Greece, France, Finland, Denmark, and Belgium. In the remaining cases, setting all respondents to have 0 cultural concerns results in larger falls in support than doing the same for economic concerns (the largest differences are seen in Switzerland, Hungary, Poland and Slovakia). Setting each type of concern to their maximum values reveals that in three countries economic concerns play a larger role (Norway, Netherlands, and Bulgaria), in six countries results in a bigger role for cultural concerns but by less than $2 \%$, and in the remaining cases setting cultural concerns to their maximum values results in a higher score by more than $2 \%$ (see table A4.4 for specific numbers).

\section{--- Figure 7 about here ---}

In sum, having individual cultural concerns over immigration has a strong impact on voting for far right parties, but economic concerns also increase support for the far right and there are more people with economic than cultural concerns, both in the broader population and among many successful far right parties' electorate. In many - but not all - cases an electorate that has maximum cultural concerns over immigration would in principle yield the maximum support for far right parties But this is not always the case and the predictive power of economic concerns at the individual level are correlated with national level support, while 
this is not the case for cultural concerns. Thus, mobilising those with economic concerns over immigration is always important to far right party success and in many cases the driving force of their success.

\section{Conclusion}

This article suggests that studies focusing on the anti-immigration drivers of far right party support should pay more attention both to voters' socio-tropic economic concerns as well as the important distinction between mobilising a core constituency on the one hand, and the ability to extend support beyond this core constituency on the other. In a nutshell, our argument is that while cultural concerns over immigration may be a stronger predictor of far right party voting, this does not mean that culture necessarily and always matters more for far right party success than the economy. This is because, first, as shown in our analysis of 8 waves of ESS data between 2002 and 2016, concerns about the impact of immigration on the country's economy as a whole are statistically significant and have a strong positive association with voting for the far right.

Second, those who dislike the impact of immigration on the economy are important to the far right in numerical terms as they allow these parties to extend their support beyond their secure voting base. These findings confirm that the far right parties that are more likely to be electorally successful are those able to mobilise a 'winning anti-immigrant coalition' which consists of both the vast majority of the few core supporters who care strongly about the cultural impact of immigration and a subset of the numerically larger group of voters who care strongly about the economic impact of immigration. 
This article makes several contributions by challenging a key assumption, which is increasingly becoming consensus in the literature, that culture predominantly drives support for the far right within the context of an emerging transnational cleavage.

First, by presenting an empirical reassessment of theories that examine the relationship between different concerns over immigration and success of far right parties using 8 waves of ESS survey data, we show how and why economic considerations over the impact of immigration also drive far right party success. Existing literature in the field has repeatedly stressed the need for further research that nuances the role of economic anxiety (Mudde and Rovira Kaltwasser 2018), distinguishes between the perceived economic and cultural threats posed by immigration and their effect on far right support (Lucassen and Lubbers 2012: 549) and identifies 'how, when and why' socio-tropic concerns matter (Hainmueller and Hopkins 2014: 225). This article addresses this gap in the literature, and in doing so it brings the economy back in the debate on far right voting within the context of the transnational cleavage.

Second, we point to an important methodological problem arising from inferring what 'causes' a cross-national level phenomenon using individual level findings. While the ecological fallacy has been front and centre of the recent drive to use more individual voting data rather than national electoral results, little attention to date has been paid to the reverse risk of the individualistic, or atomistic, fallacy. In this article, we advocate for paying closer attention to descriptive information such as the size and composition of different far right voter groups. We also illustrate the kinds of tests and simulations that researchers can carry out to explore complex multilevel interactions and assess the severity of the atomistic fallacy.

Our article also opens avenues for future research. First, it could form the basis of future research aiming at more targeted examinations of the role of other (including non- 
immigration related) economic drivers of far right party support. As our article suggests that identifying the probability of voting for the far right at the individual level is not in itself sufficient in establishing the causes of far right party success, future research could test these conclusions by focusing more closely on the specific mechanisms that link voting preferences to far right party success. For example, the adoption of a targeted sampling strategy (see Malhotra et. al 2013) might identify trends not prevalent among the general population, and hence not visible in surveys such as the ESS.

Second, another important issue raised in our article is the multi-faceted character of the immigration issue and the extent to which this multi-dimensionality suggests that immigration should not be treated as merely a cultural variable in theories of far right party support. This point has been previously raised (Rydgren 2008), and more work is needed, extending beyond the economy-culture dichotomy and examining more dimensions of antiimmigration attitudes. For instance, this could include the extent to which voters are concerned about the impact of immigration on their personal safety, because of increased crime levels and/ or terrorism; and on the provision of public goods, i.e. deteriorating public services. A related point is that of data availability: the research community would benefit from new or extended surveys that include more elaborate questions on the cultural and security threat dimensions of anti-immigration attitudes. This will allow us to more adequately measure and operationalize anti-immigration attitudes in a manner that captures all the threat dimensions that trigger them.

Third, demand-side insights emphasised here can be linked to supply, both in terms of far right party strategies and in terms of other parties such as the centre-right that also draw on the increasing salience of immigration. Indeed, our article has briefly discussed some conclusions from recent literature, which show that far right parties focus increasingly on social welfare (Afonso and Renwald 2017; Röth et al 2018; Afonso and Papadopoulos 2015; 
Halikiopoulou and Vlandas 2019), in order to appeal to those voters with economic concerns, thus complementing our findings. The field would benefit significantly from more mixed methods approaches that focus on the complementarity between demand and supply-side dynamics and the ways in which multiple and overlapping societal grievances are targeted by far right parties.

Overall, our findings have significant policy implications. If we are right then the economic dimension of far right party support is often underestimated. In order to address the success of these parties, policy-makers need to pay attention not only to policies related to national identity and cultural values, but also to the underlying economic insecurities that trigger those anti-immigration sentiments, which in turn often translate in voting for the far right. 


\section{References}

Adler, David \& Ben Ansell (2020) Housing and populism, West European Politics, 43:2, 344-365.

Afonso, Alexandre and Line Rennwald. 2017. "Social class and the changing welfare state agenda of Populist Radical Right Parties in Europe", in Philip Manow, Bruno Palier and Hannah Schwander (eds), Electoral Realignments and Welfare State Transformations in Europe, Oxford: Oxford University Press.

Afonso, Alexandre \& Yiannis Papadopoulos. 2015. "How the Populist Radical Right Transformed Swiss Welfare Politics: From Compromises to Polarization”, Swiss Political Science Review.

Artiles, Antonio Martin and Guglielmo Meardi. 2014. "Public opinion, immigration and welfare in the context of uncertainty, European Trade Union Institute.” 20:1, pp. 53-68.

Arzheimer, Kai. 2009. "Contextual Factors and the Extreme Right Vote in Western Europe, 1980- 2002.” American Journal of Political Science 53, 259-275.

Breuilly, John. 2005. Dating the nation: How old is an old nation? In Atsuko. Ichijo \& Gordana. Uzelac (eds), When is the nation? Towards an understanding of theories of nationalism. London: Routledge.

Bryan, Mark, L. and Stephen P. Jenkins. 2016. "Multilevel Modelling of Country Effects: A Cautionary Tale. European Sociological Review." Vol. 32, No. 1, 3-22

Burns, Peter and James G. Gimpel. 2000. "Economic Insecurity, Prejudicial Stereotypes, and Public Opinion on Immigration Policy.” Political Science Quarterly, 115: 2, pp. 201-225 
Chandler, Charles and Yung Mei Tsai. 2001. "Social factors influencing immigration attitudes: an analysis of data from the General Social Survey." The Social Science Journal 38, pp. $177-188$

Citrin J, Green DP, Muste C, Wong C. 1997. "Public opinion toward immigration reform: the role of economic motivations." J. Polit. 59:858-81

Citrin, Jack and John Sides. 2008. "Immigration and the Imagined Community in Europe and the United States.” Political Studies, 56, pp. 33-56

Colantone, Italo, and Piero Stanig 2018. “The Trade Origins of Economic Nationalism', American Journal of Political Science, 62:4, 936-53.

Croon, M. A., \& van Veldhoven, M. J. P. M. 2007. Predicting group-level outcome variables from variables measured at the individual level: A latent variable multilevel model. Psychological Methods, 12(1), 45-57.

Dancygier, Rafaela M. and Michael J. Donnelly. 2013. “Sectoral Economies, Economic Contexts, and Attitudes toward Immigration.” The Journal of Politics, 75: 1, pp. 17-35.

Engler, S. and Weisstanner, D. 2020), "Income inequality, status decline and support for the radical right." Journal of European Public Policy, Online first $3^{\text {rd }}$ March 2020.

Gidron, N. and Hall, P. A. (2017), “The politics of social status: economic and cultural roots of the populist right", British Journal of Sociology, 68, S57-S84.

Golder, Matt. 2003. "Explaining Variation In The Success Of Extreme Right Parties In Western Europe.” Comparative Political Studies; 36; 432.

Golder, Matt. 2016. "Far right parties in Europe." Annual Review of Political Science 19: 477-97. 
Hainmueller, Jens and Daniel J. Hopkins. 2014. "Public attitudes towards immigration, Annual Review of Political Science." 17:225-249

Halikiopoulou Daphne and Tim Vlandas. 2016. "Risks, costs and labour markets: explaining cross-national patterns of far right party success in European Parliament elections." Journal of Common Market Studies.

Halikiopoulou, Daphne and Tim Vlandas (2019 forthcoming) "What is new and what is nationalist about Europe's new nationalism? Explaining the rise of the far right in Europe, Nations and Nationalism

Halla, Martin, Alexander F Wagner Josef Zweimüller (2017). "Immigration and Voting for the Far Right", Journal of the European Economic Association, Volume 15, Issue 6, 1 December 2017, Pages 1341-1385.

Häusermann, Silja and Schwander, Hanna. 2009. "Identifying outsiders across countries: similarities and differences in the patterns of dualization." RECWOWE working paper.

Hellwig, Timothy and Yesola Kweon. 2016. "Taking cues on multidimensional issues: the case of attitudes toward immigration.” West European Politics, 39:4, pp.710-730

Hooghe, Lisbet and Gary Marks. 2017. "Cleavage theory meets Europe's crises: Lipset, Rokkan, and the transnational cleavage." Journal of European Public Policy.

Hox, Joop (2010) Multilevel Analysis: Techniques and Application. Routledge. Inglehart, Ronald and Pippa Norris. 2016. "Trump, Brexit, and the Rise of Populism: Economic Have-Nots and Cultural Backlash”, Harvard Kennedy School Faculty Research Working Paper Series [accessed on 26/01/17] 
Ivarsflaten, Elisabeth. 2008. "What unites right-wing populists in Western Europe? Reexamining grievance mobilization models in seven successful cases." Comparative Political Studies, 41: 3- 23.

Kaufmann, Eric. 2017. "Levels or changes?: Ethnic context, immigration and the UK Independence Party vote.” Electoral Studies 48, pp. 57-69

Kinder DR, Kiewiet DR. 1981. Sociotropic politics: the American case. British Journal of Political Science. 11, pp. 129-61

Kitchelt, Herbert. 2018. “A Simpleton's Sketch of Politics in the Knowledge Society and the Role of Populist Radical Right and Left”, workshop on Radicalism and Realignment. Duke University. Department of Political Science, April 20 and April 21

Kriesi, Hanspeter. (1998). The transformation of cleavage politics: the 1997 Stein Rokkan lecture, European Journal of Political Research, 33, pp. 165-185

Lubbers, Marcel and Marcel Coenders. 2017. "Nationalistic attitudes and voting for the radical right in Europe.” European Union Politics, 18: 1, pp. 98 - 118

Lubbers, Marcel and Peer Scheepers. 2002. "French Front National voting: a micro and macro perspective". Ethnic and Racial Studies, 25:120-49

Lubbers, Marcel and Ayse Güveli. 2007. "Voting LPF: Stratification and the varying importance of attitudes". Journal of Elections, Public Opinion and Parties, 17, 21-48.

Lucassen, Geertje and Marcel Lubbers. 2012. "Who Fears What? Explaining Far-Right-Wing Preference in Europe by Distinguishing Perceived Cultural and Economic Ethnic Threats.” Comparative Political Studies, 45(5): 547-574. 
Malhotra, Neil, Yotam Margalit, Y. and Cecilia Hyunjung Mo,. (2013), Economic Explanations for Opposition to Immigration: Distinguishing between Prevalence and Conditional Impact. American Journal of Political Science, 57: 391-410.

Marx, Paul. 2014. "Labour Market Risks and Political Preferences: The Case of Temporary Employment." European Journal of Political Research, 53(1): 136-159.

Mayda, Anna Maria. 2006. "Who is against immigration? A cross-country investigation of individual attitudes toward immigrants." The Review of Economics and Statistics, 88:3, pp. $510-530$

Mudde, Cas. 2007. Populist radical right parties in Europe. Cambridge: Cambridge University Press.

Mudde, Cas. 2012. "The relationship between immigration and nativism in Europe and north America", Washington DC: Migration Policy Institute [accessed on 24/11/17]

Mudde, Cas and Cristóbal Rovira Kaltwasser. (2018). "Studying Populism in Comparative Perspective: Reflections on the Contemporary and Future Research Agenda", Comparative Political Studies.

Oesch, Daniel. 2008. “Explaining Workers' Support for Right-Wing Populist Parties in Western Europe: Evidence from Austria, Belgium, France, Norway, and Switzerland.” International Political Science Review, Vol. 29: 3, pp. 349-373

Polavieja, Javier. G. 2016. “Labour-market competition, recession and anti-immigrant sentiments in Europe: occupational and environmental drivers of competitive threat." SocioEconomic Review, 14: 3, pp. 395-417 doi: 10.1093/ser/mww002

Rehm, Philipp. 2016. Risk Inequality and Welfare States. Cambridge et al.: Cambridge University Press. 
Rooduijn, Matthijs and Burgoon, Brian. 2018. "The Paradox of Well-being: Do Unfavorable Socioeconomic and Sociocultural Contexts Deepen or Dampen Radical Left and Right Voting Among the Less Well-Off?” Comparative Political Studies.

Rooduijn, Matthijs, Brian Burgoon, Erika J van Elsas and Herman G van de Werfhorst. 2017. "Radical distinction: Support for radical left and radical right parties in Europe", European Union Politics, 18: 4, pp. 536 - 559

Röth, Leonce, Alexandre Afonso \& Dennis. C. Spies. 2018. "The impact of Populist Radical Right Parties on socio-economic policies”. European Political Science Review, 10(3), 325350.

Rovny, Allison. E. and Jan Rovny. 2017, “Outsiders at the ballot box: operationalizations and political consequences of the insider-outsider dualism", Socio-Economic Review, Volume 15, Issue 1, 1 January 2017, Pages 161-185

Rueda, David. 2007. Social democracy inside out. Partisanship and labour market policy in industrialised democracies, ed. Oxford University Press (Oxford).

Rydgren, Jens. 2008. "Immigration sceptics, xenophobes or racists? Radical right-wing voting in six West European countries”. European Journal of Political Research, 47: 737765.

Scheve Kenneth. F and Matthew J. Slaughter. 2001. "Labour market competition and individual preferences over immigration" Policy Rev. Econ. Stat. 83:133-45

Sniderman, Paul M., Louk Hagendoorn and Markus Prior. 2004. "Predisposing factors and situational triggers: Exclusionary reactions to immigrant minorities". American Political Science Review, 98, 35-49. 
Stegmueller, Daniel. 2013. "How Many Countries for Multilevel Modelling? A Comparison of Frequentist and Bayesian Approaches." American Journal of Political Science, Vol. 57, No. 3, July 2013, Pp. 748-761.

Stockemer, Daniel. 2016. "Structural Data on Immigration or Immigration Perceptions? What Accounts for the Electoral Success of the Radical Right in Europe?" JCMS: Journal of Common Market Studies, 54: 4, pp. 999-1016.

Swank, D. and Betz, H.G. 2003 “Globalization, the Welfare State and Right-Wing Populism in Western Europe". Socio-Economic Review, Vol. 1, pp. 215-45.

Swank, D. and Betz, H. G. 2018. “Globalization, Institutions of Social Solidarity, and Radical Right-Wing Populism in Western Europe”, Paper prepared for presentation at the 2018 Annual Meetings of the American Political Science Association, August 30 - September 2, Boston, MA.

Tilley, James and Geoffrey Evans. 2017. "The new politics of class after the 2017 General Election." The Political Quarterly.

Van der Brug, Wouter and Meindert Fennema, M. 2007. "What causes people to vote for a radical-right party? A review of recent work. ” International Journal of Public Opinion Research 19(4): 474-487.

Van der Brug, Wouter, Meindert Fennema and Jean Tillie. 2005. "Why Some AntiImmigrant Parties Fail and Others Succeed: A Two-Step Model of Aggregate Electoral Support.” Comparative Political Studies, 38: 5, pp. 537-573.

Van Elsas, Erika. J, Armen Hakhverdian and Wouter Van der Brug. 2016. "United against a common foe? The nature and origins of Euroscepticism among left-wing and right-wing citizens." West European Politics Vol. 39: 6, pp. 1181-1204 
Van Spanje Joost. 2010. "Contagious parties: Anti-immigrant parties and their impact on other parties' immigration stances in contemporary Western Europe.” Party Politics 16 (5), pp. 563-586

Vasilopoulou, Sofia and Daphne Halikiopoulou. 2015. The Golden Dawn's nationalist Solution: Explaining the Rise of the Far Right in Greece, New York: Palgrave.

Vlandas, Tim and Daphne Halikiopoulou. 2018. "Does unemployment matter? Economic insecurity, labour market policies and the far right vote in Europe", European Political Science

Vlandas, Tim. 2013. "The Politics of Temporary Work Deregulation in Europe: Solving the French Puzzle", Politics \& Society, 41 (3), 425-60. 
Figure 1: Distribution of respondents with cultural (panel above) and economic (panel below) concerns over immigration

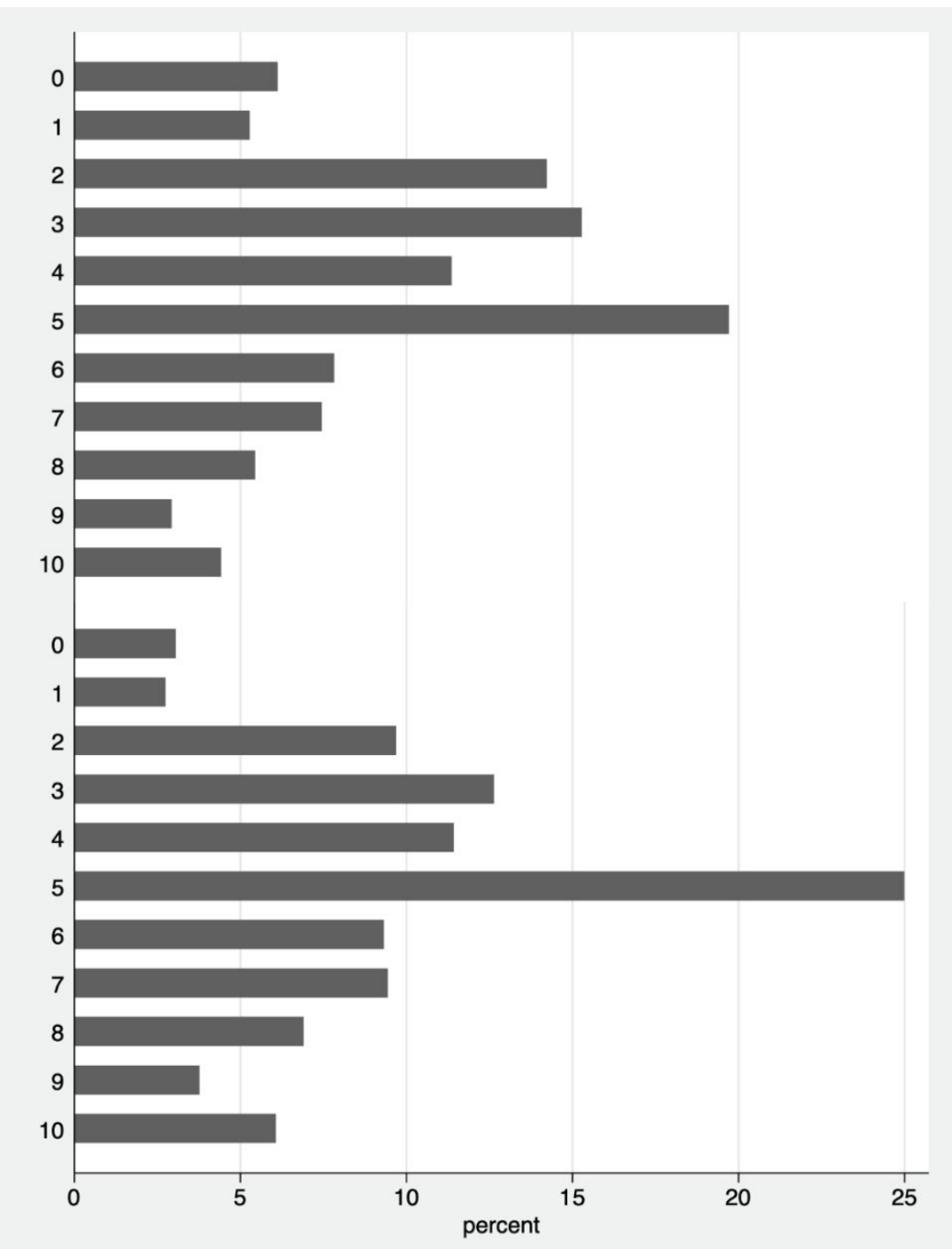


Figure 2: Hypothetical example illustrating the importance of group size

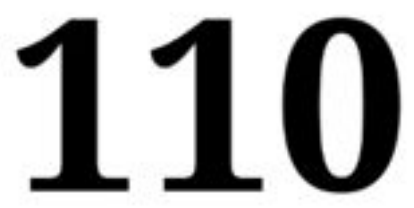

NUMBER OF PEOPLE

IN ELECTORATE

\section{ECONOMICALLY INSECURE}

$10 \%$ of ecconomically insecure vote tor the
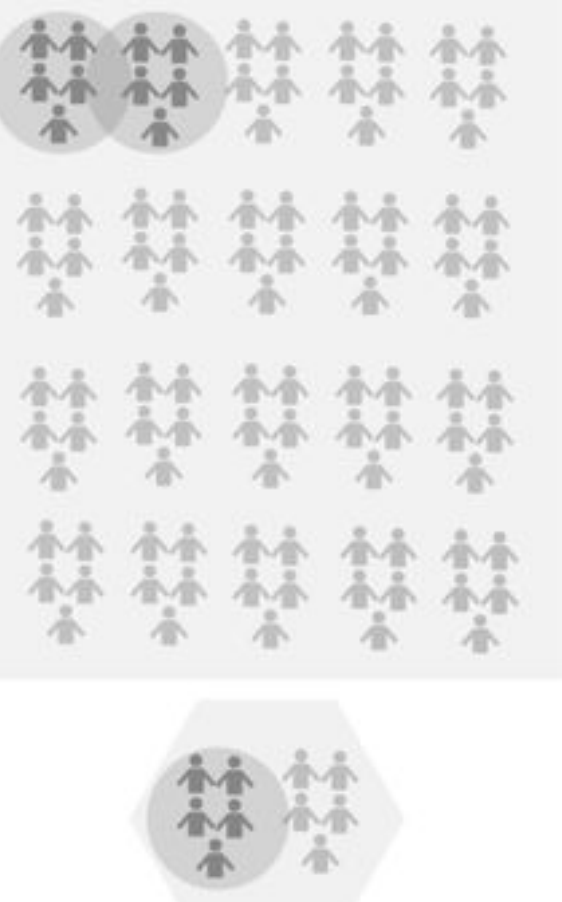

CULTURALLY INSECURE

$50 \%$ it culturally insecure vote for 
Figure 3: Predicted probability of voting for the far right for different combinations of economic and cultural concerns over immigration

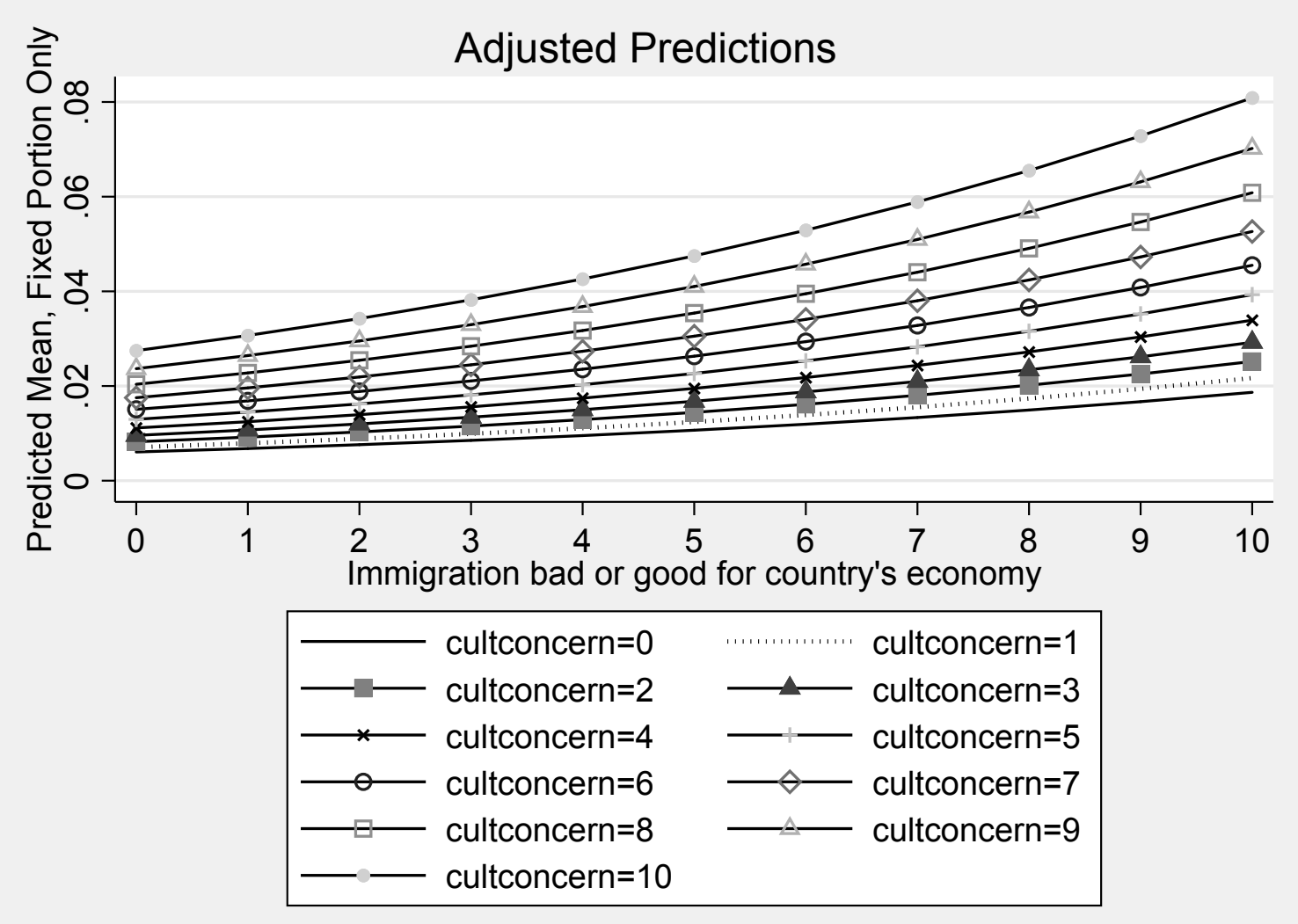

Note: the predicted probabilities were calculated using the coefficients from column 8 in table 1. 
Figure 4: Number of far right and non-far right voters with different levels of cultural (panel above) and economic (panel below) concerns

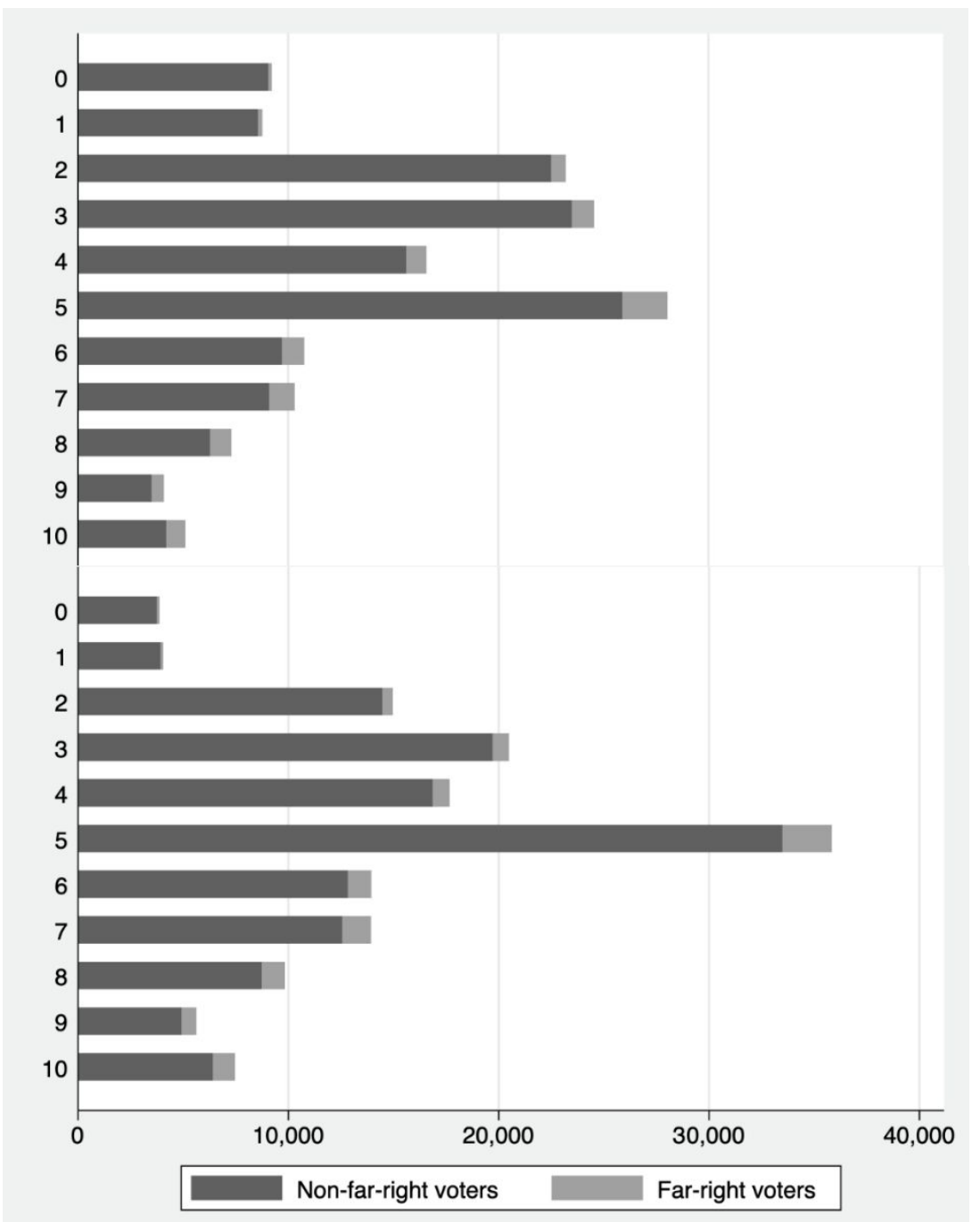


Figure 5: Distribution of concerns among far right voters (cut-off point of 5)

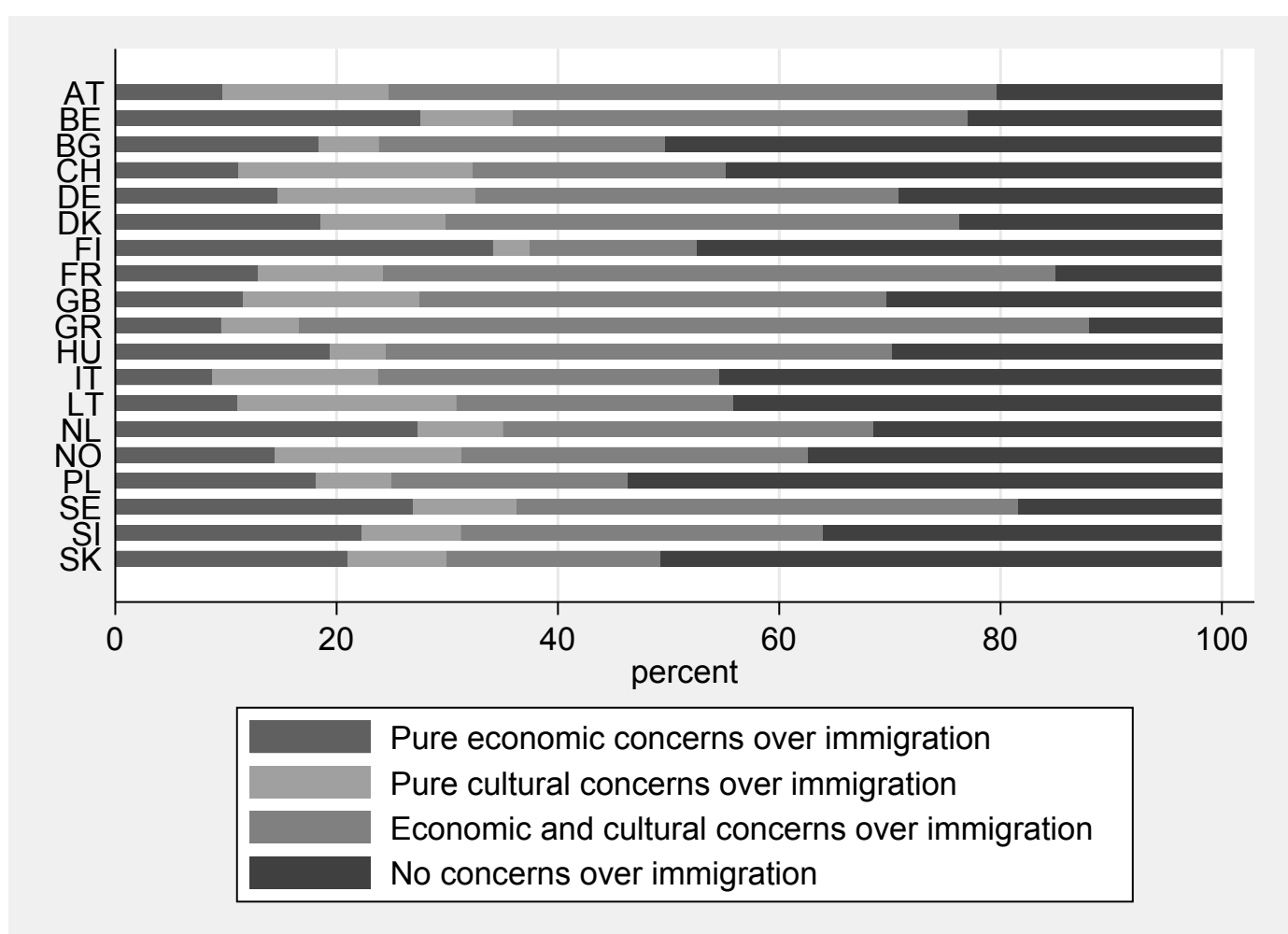


Figure 6: Percentage of far right voters among the total population versus among voters with immigration concerns

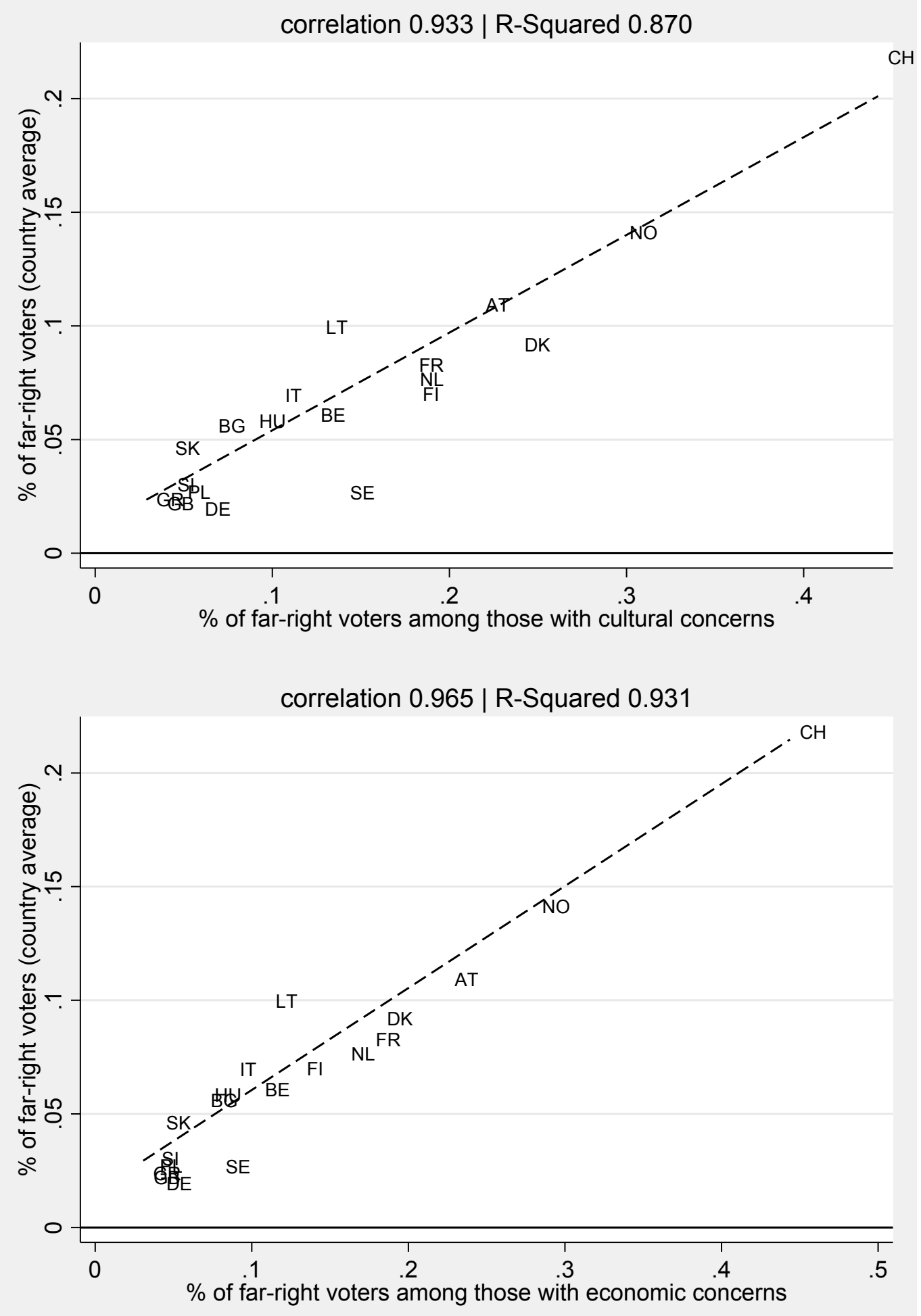

Note: a cut-off point of 5 is used to identify who has concerns. 
Figure 7: Simulations of predicted country level far right party support for different hypothetical distributions of economic and cultural concerns

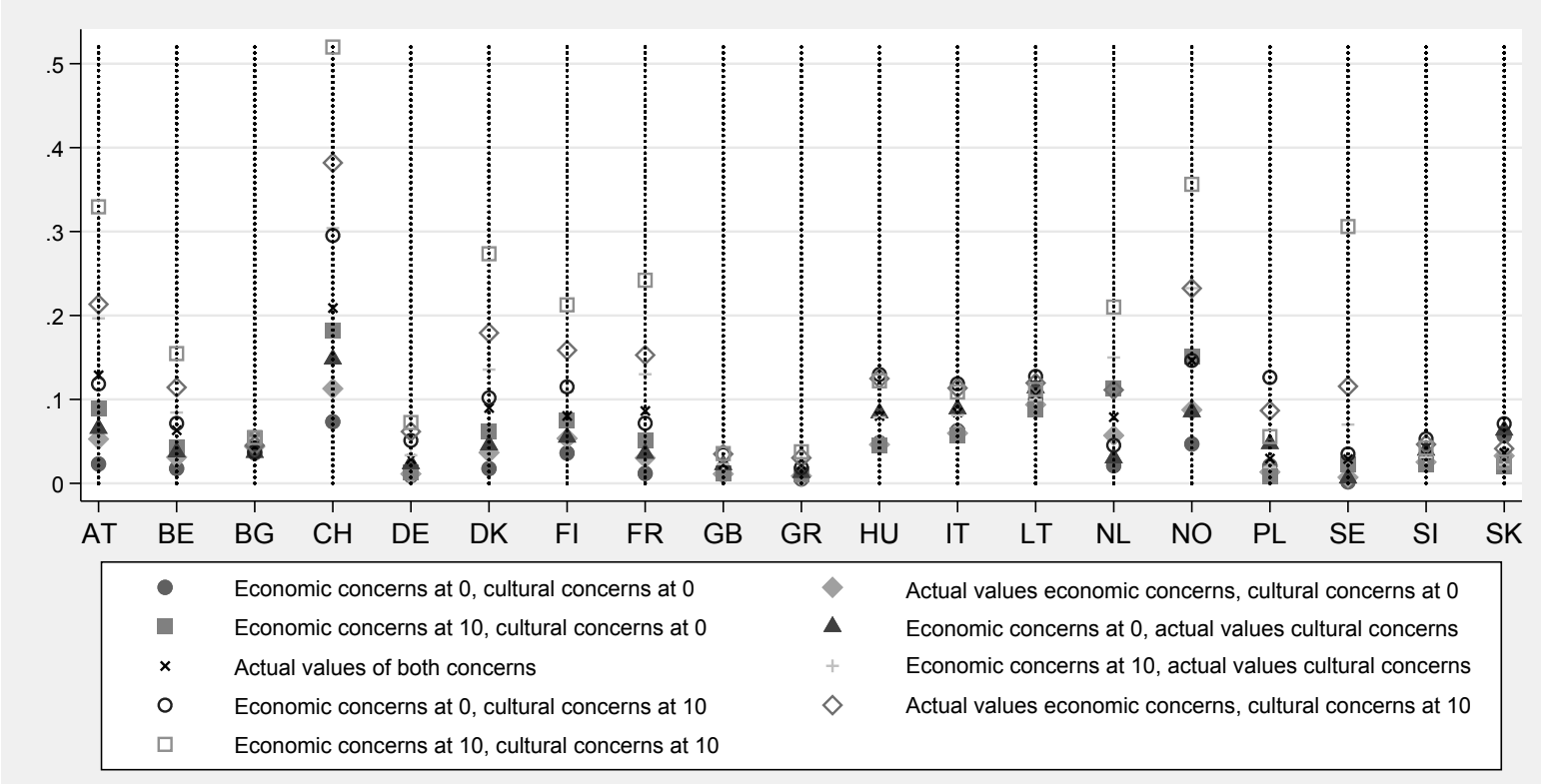


Table 1: Economic and cultural concerns over immigration and far right voting

\begin{tabular}{|c|c|c|c|c|c|c|c|c|c|}
\hline Column & 1 & 2 & 3 & 4 & 5 & 6 & 7 & 8 & 9 \\
\hline Economic concerns over immigration & $0.175 * * *$ & $0.162 * * *$ & $0.164 * * *$ & $0.163 * * *$ & $0.152 * * *$ & $0.120 * * *$ & $0.114 * * *$ & $0.114 * * *$ & 3.61 \\
\hline Cultural concerns over immigration & $0.235 * * *$ & $0.222 * * *$ & $0.192 * * *$ & $0.192 * * *$ & $0.188 * * *$ & $0.161 * * *$ & $0.153 * * *$ & $0.153 * * *$ & 5.3 \\
\hline Male & $0.480 * * *$ & $0.482 * * *$ & $0.429 * * *$ & $0.432 * * *$ & $0.390 * * *$ & $0.435 * * *$ & $0.403 * * *$ & $0.409 * * *$ & 1.35 \\
\hline Age & $-0.011 * * *$ & $-0.016 * * *$ & $-0.017 * * *$ & $-0.015 * * *$ & $-0.012 * * *$ & $-0.013 * * *$ & $-0.014 * * *$ & $-0.014 * * *$ & -4.4 \\
\hline Bottom income dummy & 0.064 & -0.025 & 0.056 & 0.008 & -0.026 & -0.056 & -0.062 & & \\
\hline Lower half of income dummy & & & & & & & & $0.101 * * *$ & 0.33 \\
\hline Education (in years) & & $-0.070 * * *$ & $-0.075 * * *$ & $-0.075 * * *$ & $-0.043 * * *$ & $-0.038 * * *$ & $-0.038 * * *$ & $-0.037 * * *$ & -4.716 \\
\hline \multicolumn{10}{|l|}{ Reference category: wages } \\
\hline Self-employed & & & & $-0.236 * * *$ & $-0.181 * * *$ & $-0.202 * * *$ & $-0.211 * * *$ & $-0.213 * * *$ & -0.66 \\
\hline Pensions & & & & $-0.099 * *$ & $-0.097 * *$ & $-0.095 * *$ & $-0.082 *$ & $-0.117 * * *$ & -0.38 \\
\hline Unemployed & & & & $0.400 * * *$ & $0.396 * * *$ & $0.366^{* * *}$ & $0.393 * * *$ & $0.328 * * *$ & 1.23 \\
\hline Other social benefits & & & & $0.241 * * *$ & $0.216 * * *$ & $0.187 * *$ & $0.193 * *$ & 0.130 & 0.45 \\
\hline Investments & & & & -0.268 & -0.223 & -0.217 & -0.205 & -0.210 & -0.64 \\
\hline Other sources & & & & $-0.334 * *$ & $-0.309 *$ & $-0.285^{*}$ & -0.239 & $-0.294 *$ & -0.88 \\
\hline Placement on left-right scale & & 8 & $0.242 * * *$ & $0.245 * * *$ & $0.254 * * *$ & $0.272 * * *$ & $0.272 * * *$ & $0.273 * * *$ & 9.237 \\
\hline \multicolumn{10}{|l|}{ Reference category: manager } \\
\hline Professional & & & & & $-0.215^{* * *}$ & $-0.204 * * *$ & $-0.191 * * *$ & $-0.193 * * *$ & -0.6 \\
\hline Technician & & & & & $0.157 * * *$ & $0.154 * * *$ & $0.184 * * *$ & $0.178 * * *$ & 0.62 \\
\hline Clerical & & & & & $0.329 * * *$ & $0.325 * * *$ & $0.358 * * *$ & $0.347 * * *$ & 1.29 \\
\hline Service & & & & & $0.568 * * *$ & $0.541 * * *$ & $0.547 * * *$ & $0.530 * * *$ & 2.05 \\
\hline Agriculture & & & & & $0.266 * * *$ & $0.283 * * *$ & $0.259 * * *$ & $0.226 * *$ & 0.82 \\
\hline Craft & & & & & $0.638 * * *$ & $0.587 * * *$ & $0.624 * * *$ & $0.605 * * *$ & 2.4 \\
\hline Operator & & & & & $0.667 * * *$ & $0.603 * * *$ & $0.622 * * *$ & $0.603 * * *$ & 2.44 \\
\hline Elementary & & & & & $0.546 * * *$ & $0.492 * * *$ & $0.511 * * *$ & $0.482 * * *$ & 1.88 \\
\hline Trust in National Parliament & & & & & & $-0.188 * * *$ & $-0.140 * * *$ & $-0.139 * * *$ & -4.47 \\
\hline Trust in European Parliament & & & & & & & $-0.097 * * *$ & $-0.097 * * *$ & -3.01 \\
\hline Constant & $-5.155 * * *$ & $-3.920 * * *$ & $-5.033 * * *$ & $-5.061 * * *$ & $-5.848 * * *$ & $-4.900 * * *$ & $-4.562 * * *$ & $-4.624 * * *$ & \\
\hline Observations & 124,046 & 123,674 & 119,680 & 117,971 & 113,175 & 112,730 & 106,950 & 106,950 & \\
\hline Number of groups & 123 & 123 & 123 & 122 & 122 & 122 & 122 & 122 & \\
\hline Log likelihood & -24658 & -24385 & -22731 & -22642 & -21570 & -21048 & -19864 & -19860 & \\
\hline Wald Chi2 & 5043 & 5234 & 6103 & 6125 & 6132 & 6690 & 6474 & 6478 & \\
\hline Prob $>$ chi 2 & 0 & 0 & 0 & 0 & 0 & 0 & 0 & 0 & \\
\hline
\end{tabular}

Note: this table presents the results from a multilevel mixed-effects logistic regression taking into account the hierarchical nature of the data; the standard errors are robust and clustered by country-wave. $* * * p<0.01, * * p<0.05, * p<0.1$. Column 9 reports the \% change in the predicted probability when the independent variable is set at its maximum value minus when it is set at its minimum value, holding all other independent variables at their mean value. 
Table 2: Individual level coefficients and far right party success at the country-wave level

\begin{tabular}{lccc}
\hline Column & $(1)$ & $(2)$ & $(3)$ \\
\hline Variable composed of country-wave logistic regression & & & \\
coefficient of economic concerns & $0.0797^{* * *}$ & & $0.0857^{* * *}$ \\
Variable composed of country-wave logistic regression & & & \\
coefficient of cultural concerns & & 0.0153 & 0.0381 \\
\hline Constant & $0.07384^{* * * *}$ & $0.07916^{* * * *}$ & $0.06752^{* * *}$ \\
Observations & 108 & 108 & 108 \\
R-squared & 0.05 & 0.00 & 0.05 \\
\hline
\end{tabular}

Notes: Robust standard errors in parentheses, $* * * p<0.01,{ }^{*} p<0.05, * p<0.1$. This regression is run using a country-wave level dataset. The dependent variable is the country-wave average far right party success. The two independent variables are coefficients from the respective country-wave logistic regression of individual far right party votes on economic and cultural concerns, with a series of individual level controls. Thus, each coefficient captures the size of the impact of an individual having economic and cultural concerns, respectively, on the probability of voting for the far right in that specific country-wave. 


\title{
Appendix
}

\section{When economic and cultural interests align: the anti-immigration voter coalitions driving far right party success in Europe}

\author{
Last updated $14^{\text {th }}$ March 2020
}

\section{Contents}

Appendix 1. Party classification.....

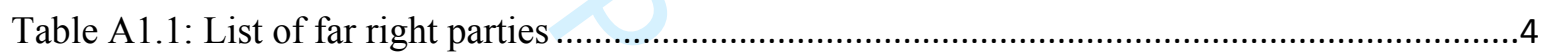

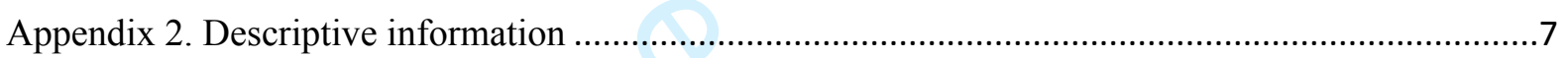

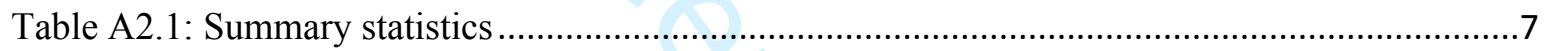

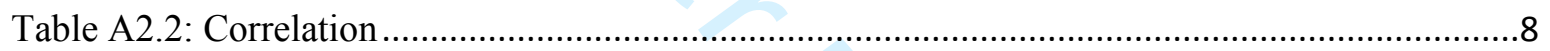

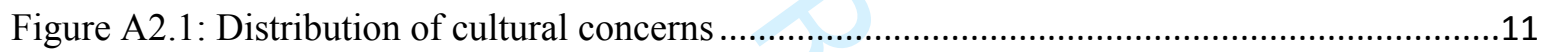

Figure A2.2: Distribution of economic concerns.....................................................................11

Figure A2.3: Percentage of far right voters in the entire electorate and among those with cultural concerns

Figure A2.4: Percentage of far right voters in the entire electorate and among those with economic concerns.

Figure A2.5: Percentage of far right voters in the entire electorate versus percentage of far right voters with economic concerns (left hand side) and percentage of far right voters with cultural concerns (right hand side).

Figure A2.6: Number of far right and non-far right voters with different levels of cultural concerns

Figure A2.7: Number of far right and non-far right voters with different levels of economic concerns.

Table A2.3. Far right voters with economic and cultural concerns

Figure A2.8. Distribution of concerns among far right voters (cut-off point of 5)

Figure A2.9. Distribution of concerns among far right voters (cut-off point of 7)

Figure A2.10. Percentage of far right voters overall when manipulating the numbers of voters with different immigration concerns (cut-off point of 5).

Figure A2.11. Percentage of far right voters overall when manipulating the numbers of voters with different immigration concerns (cut-off point of 7). 
Appendix 3. Main regression tables - without PiS (starts on next page).

Table A3.1.a. Multilevel random intercept logistic regression table - baseline without PiS ............20

Table A3.1.b. Average marginal effects for key variables of column 8 in table A3.1.a ..................21

Figure A3.1. Predicted probabilities using column 8 of table A3.1.a ..............................................21

Figure A3.2. Predicted probabilities using column 9 of table A3.1.a .............................................22

Table A3.2. Multilevel random intercept logistic regression table - baseline without PiS - different proxies for trust.

Table A3.3.a. Multilevel random intercept logistic regression table - binary concern variables without PiS

Table A3.3.b. Average marginal effects of key variables in Table A3.3.a .....................................24

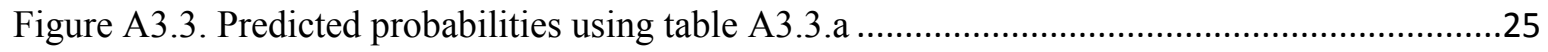

Table A3.4. Multilevel random intercept logistic regression table - binary concern variables with

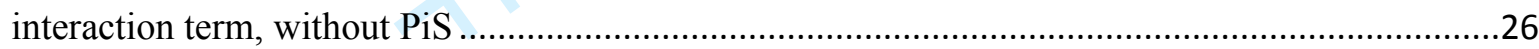

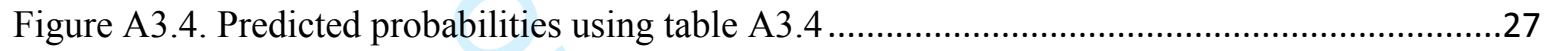

Table A3.5.a. Multilevel random intercept logistic regression table - bining concerns into four

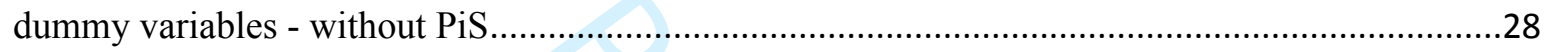

Table A3.5.b. Average marginal effects of key variables in Table A3.5.a .....................................29

Table A3.6: Distribution of materialists and culturalists using binary variables ...............................30

Table A3.7: Distribution of far right voters among strict materialists and strict culturalists ............30

Table A3.8. Relationship between individual level coefficients and votes for far right parties at the

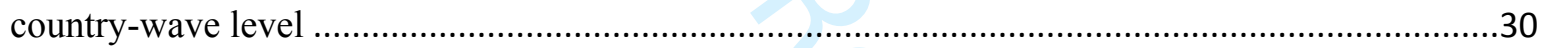

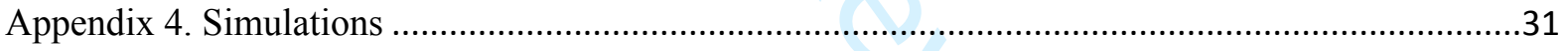

Table A4.1. A hypothetical far right electorate with anti-immigration concerns ............................31

Table A4.2. A hypothetical far right electorate: tabulation of far right voters and anti-immigration

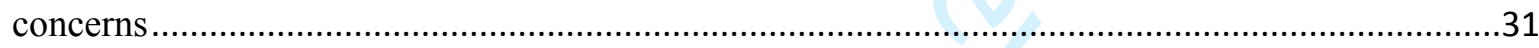

Table A4.3. A hypothetical far right electorate: regression results.................................................31

Figure A4.1: Simulations of predicted country level far right party support for different hypothetical distributions of economic and cultural concerns by country ......................................32

Table A4.4. Estimates from country specific regressions ................................................................33

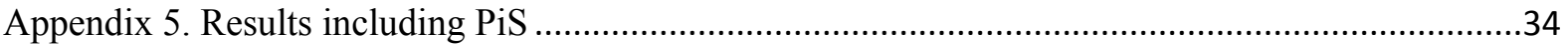

Table A5.1. Economic concerns and far right voters - with PiS .....................................................34

Table A5.2. Cultural concerns and far right voters - with PiS .......................................................34

Table A5.3. Multilevel random intercept logistic regression table -with PiS.................................35

Figure A5.1: Predicted probabilities using column 8 of table A5.3 ……........................................36 


\section{Appendix 1. Party classification}

We adopt the term 'far right' in accordance with Lucassen and Lubbers (2012). As we similarly distinguish between perceived cultural and economic concerns over immigration and the extent to which they impact on support for such parties, we deem it appropriate to adopt similar terminology. We define 'far right' parties as parties that propose nationalist solutions to a variety of socio-economic problems (Vasilopoulou and Halikiopoulou 2015), compete along the national identity axis (Ellinas 2011) and 'own' the immigration issue (Van Spagne 2010; Lucassen and Lubbers 2012).

We examine a total of 31 parties in our empirical analysis (see table A1.1). Because our sample of countries is larger than that of Lucassen and Lubbers (2012), who focus on 11 countries and use data only from the first round of the ESS (2002-2003), we extend their list using a similar classification as that offered in other articles that use larger samples (e.g. Immerzeel et al 2015; Halikiopoulou and Vlandas 2016) and examine more recent ESS waves (e.g. Rooduijn and Burgoon 2018). We exclude the N-VA and Fidesz from our analysis as none of these sources code these parties as 'far right'. We consider PiS as a borderline case given that the literature is divided on this party: Immerzeel and et al (2015) code it as Conservative whereas Harrison and Bruter (2011), Pankowski and Kormak (2013) and Halikiopoulou and Vlandas (2016) code it as 'far right'. Results that include PiS are presented in appendix 5. 
Table A1.1: List of far right parties

\begin{tabular}{|c|c|c|c|c|}
\hline Country & Far Right Party & $\begin{array}{l}\text { Borderline Far } \\
\text { Right Party }\end{array}$ & ESS Wave & Source \\
\hline Austria & $\begin{array}{l}\text { Austrian Freedom } \\
\text { Party (FPÖ) }\end{array}$ & & $\begin{array}{l}\mathrm{R} 1, \mathrm{R} 2, \mathrm{R} 3 \\
\text { and R7, R8 }\end{array}$ & $\begin{array}{l}\text { Lucassen and Lubbers } \\
\text { 2012; Immerzeel et al } \\
\text { 2015; Rooduijn and } \\
\text { Burgoon } 2017\end{array}$ \\
\hline Austria & $\begin{array}{l}\text { Alliance for the } \\
\text { Future of Austria } \\
\text { (BZÖ) }\end{array}$ & & $\begin{array}{l}\text { R3 and R7, } \\
\text { R8 }\end{array}$ & $\begin{array}{l}\text { Immerzeel et al 2015; } \\
\text { Rooduijn and Burgoon } \\
2017\end{array}$ \\
\hline $\begin{array}{l}\text { Belgium } \\
\text { (Flanders) }\end{array}$ & Flemish Interest (VB) & & $\begin{array}{l}\text { R1, R2, R3, } \\
\text { R4, R5, R6 } \\
\text { and R7, R8 }\end{array}$ & $\begin{array}{l}\text { Lucassen and Lubbers } \\
\text { 2012; Immerzeel et al } \\
\text { 2015; Rooduijn and } \\
\text { Burgoon } 2017\end{array}$ \\
\hline $\begin{array}{l}\text { Belgium } \\
\text { (Wallonia) }\end{array}$ & $\begin{array}{l}\text { Front National Belge } \\
(\mathrm{FNb})\end{array}$ & & $\begin{array}{l}\text { R1, R2, R3, } \\
\text { R4, R5, R6 } \\
\text { and R7, R8 }\end{array}$ & $\begin{array}{l}\text { Lucassen and Lubbers } \\
\text { 2012; Immerzeel et al } \\
\text { 2015; Rooduijn and } \\
\text { Burgoon } 2017\end{array}$ \\
\hline Bulgaria & $\begin{array}{l}\text { National Union } \\
\text { Attack (ATAKA) }\end{array}$ & & $\begin{array}{l}\mathrm{R} 3, \mathrm{R} 4, \mathrm{R} 5 \\
\text { and R6 }\end{array}$ & Immerzeel et al 2015 \\
\hline Denmark & $\begin{array}{l}\text { Danish People's Party } \\
\text { (DF) }\end{array}$ & & $\begin{array}{l}\text { R1, R2, R3, } \\
\text { R4, R5, R6 } \\
\text { and R7 }\end{array}$ & $\begin{array}{l}\text { Lucassen and Lubbers } \\
\text { 2012; Immerzeel et al } \\
\text { 2015; Rooduijn and } \\
\text { Burgoon } 2017\end{array}$ \\
\hline Finland & True Finns (PS) & & $\begin{array}{l}\text { R1, R2, R3, } \\
\text { R4, R5, R6 } \\
\text { and R7, R8 }\end{array}$ & $\begin{array}{l}\text { Immerzeel et al 2015; } \\
\text { Rooduijn and Burgoon } \\
2017\end{array}$ \\
\hline France & Front National (FN) & & $\begin{array}{l}\text { R1, R2, R3, } \\
\text { R4, R5, R6 } \\
\text { and R7, R8 }\end{array}$ & $\begin{array}{l}\text { Lucassen and Lubbers } \\
\text { 2012; Immerzeel et al } \\
\text { 2015; Rooduijn and } \\
\text { Burgoon } 2017\end{array}$ \\
\hline France & $\begin{array}{l}\text { Mouvement National } \\
\text { Republicain (MNR) }\end{array}$ & & $\mathrm{R} 1, \mathrm{R} 2, \mathrm{R} 3$ & $\begin{array}{l}\text { Lucassen and Lubbers } \\
\text { 2012; Rooduijn and } \\
\text { Burgoon } 2017\end{array}$ \\
\hline Germany & $\begin{array}{l}\text { National Democratic } \\
\text { Party of Germany } \\
\text { (NPD) }\end{array}$ & & $\begin{array}{l}\text { R2, R3, R4, } \\
\text { R5, R6 and } \\
\text { R7, R8 }\end{array}$ & $\begin{array}{l}\text { Immerzeel et al 2015; } \\
\text { Rooduijn and Burgoon } \\
2017\end{array}$ \\
\hline Germany & $\begin{array}{l}\text { The Republicans } \\
\text { (REP) }\end{array}$ & & $\begin{array}{l}\text { R1, R2, R3, } \\
\text { R4, R5, R6 } \\
\text { and R7 }\end{array}$ & $\begin{array}{l}\text { Lucassen and Lubbers } \\
\text { 2012; Immerzeel et al } \\
\text { 2015; Rooduijn and } \\
\text { Burgoon } 2017\end{array}$ \\
\hline Germany & $\begin{array}{l}\text { Alternative for } \\
\text { Germany (AfD) }\end{array}$ & & $\mathrm{R} 8$ & Halikiopoulou 2018 \\
\hline Greece & $\begin{array}{l}\text { Popular Orthodox } \\
\text { Rally (LAOS) }\end{array}$ & & $\begin{array}{l}\mathrm{R} 2, \mathrm{R} 4 \text { and } \\
\mathrm{R} 5\end{array}$ & $\begin{array}{l}\text { Immerzeel et al 2015; } \\
\text { Rooduijn and Burgoon } \\
2017\end{array}$ \\
\hline Greece & Golden Dawn (GD) & & R5 & $\begin{array}{l}\text { Vasilopoulou and } \\
\text { Halikiopoulou 2015; } \\
\text { Halikiopoulou and } \\
\text { Vlandas } 2016 \\
\end{array}$ \\
\hline Hungary & Movement for a better & & R1, R2, R3, & Immerzeel et. Al 2015; \\
\hline
\end{tabular}




\begin{tabular}{|c|c|c|c|c|}
\hline & Hungary (Jobbik) & & $\begin{array}{l}\text { R4, R5, R6 } \\
\text { and R7, R8 }\end{array}$ & $\begin{array}{l}\text { Rooduijn and Burgoon } \\
2017\end{array}$ \\
\hline Italy & $\begin{array}{l}\text { Northern League } \\
\text { (LN) }\end{array}$ & & $\begin{array}{l}\mathrm{R} 1, \mathrm{R} 2 \text { and } \\
\mathrm{R} 6, \mathrm{R} 8\end{array}$ & $\begin{array}{l}\text { Lucassen and Lubbers } \\
\text { 2012; Immerzeel et al } \\
\text { 2015; Rooduijn and } \\
\text { Burgoon } 2017\end{array}$ \\
\hline Italy & $\begin{array}{l}\text { Allianza Nationale } \\
\text { (AN) }\end{array}$ & & $\mathrm{R} 1$ and R2 & $\begin{array}{l}\text { Rooduijn and Burgoon } \\
2017\end{array}$ \\
\hline Italy & $\begin{array}{l}\text { Fiamma Tricolore } \\
\text { (MS-FT) }\end{array}$ & & $\mathrm{R} 1$ and $\mathrm{R} 2$ & $\begin{array}{l}\text { Lucassen and Lubbers } \\
2012\end{array}$ \\
\hline Lithuania & $\begin{array}{l}\text { Order and Justice } \\
\text { Party (TT) }\end{array}$ & & $\begin{array}{l}\text { R5, R6 and } \\
\text { R7, R8 }\end{array}$ & $\begin{array}{l}\text { Halikiopoulou and } \\
\text { Vlandas } 2016\end{array}$ \\
\hline Netherlands & $\begin{array}{l}\text { List Pim Fortuyn } \\
\text { (LPF) }\end{array}$ & & $\begin{array}{l}\mathrm{R} 1, \mathrm{R} 2, \mathrm{R} 3 \\
\text { and R4 }\end{array}$ & $\begin{array}{l}\text { Lucassen and Lubbers } \\
\text { 2012; Rooduijn and } \\
\text { Burgoon } 2017\end{array}$ \\
\hline Netherlands & $\begin{array}{l}\text { Party for Freedom } \\
\text { (PVV) }\end{array}$ & & $\begin{array}{l}\text { R5, R6 and } \\
\text { R7, R8 }\end{array}$ & $\begin{array}{l}\text { Immerzeel et al 2015; } \\
\text { Rooduijn and Burgoon } \\
2017\end{array}$ \\
\hline Norway & Progress Party (FrP) & & $\begin{array}{l}\text { R1, R2, R3, } \\
\text { R4, R5, R6 } \\
\text { and R7, R8 }\end{array}$ & $\begin{array}{l}\text { Lucassen and Lubbers } \\
\text { 2012; Immerzeel et al } \\
\text { 2015; Rooduijn and } \\
\text { Burgoon } 2017\end{array}$ \\
\hline Poland & & $\begin{array}{l}\text { Law and Justice } \\
\text { Party (Pis) }\end{array}$ & $\begin{array}{l}\text { R1, R2, R3, } \\
\text { R4, R5, R6 } \\
\text { and R7, R8 }\end{array}$ & $\begin{array}{l}\text { Pankowski, 2010; } \\
\text { Harrison and Bruter } \\
\text { 2011; Pankowski and } \\
\text { Kormak 2013; } \\
\text { Halikiopoulou and } \\
\text { Vlandas } 2016\end{array}$ \\
\hline Poland & $\begin{array}{l}\text { Congress of the New } \\
\text { Right (KPN) }\end{array}$ & & $\begin{array}{l}\text { R6 and R7, } \\
\text { R8 }\end{array}$ & $\begin{array}{l}\text { Rooduijn and Burgoon } \\
2017\end{array}$ \\
\hline Poland & $\begin{array}{l}\text { League of Polish } \\
\text { Families (LPR) }\end{array}$ & & $\begin{array}{l}\text { R1, R2, R3, } \\
\text { R4 and R5 }\end{array}$ & $\begin{array}{l}\text { Lucassen and Lubbers } \\
\text { 2012; Immerzeel et al } \\
\text { 2015; Rooduijn and } \\
\text { Burgoon } 2017\end{array}$ \\
\hline Slovakia & $\begin{array}{l}\text { Slovak National Party } \\
\text { (SNS) }\end{array}$ & & $\begin{array}{l}\mathrm{R} 3, \mathrm{R} 4 \text { and } \\
\mathrm{R} 5\end{array}$ & $\begin{array}{l}\text { Immerzeel et al 2015; } \\
\text { Rooduijn and Burgoon } \\
2017\end{array}$ \\
\hline Slovenia & $\begin{array}{l}\text { Slovenian National } \\
\text { Party (SNS) }\end{array}$ & & $\begin{array}{l}\text { R1, R2, R3, } \\
\text { R4, R5, R6 } \\
\text { and R7 }\end{array}$ & $\begin{array}{l}\text { Immerzeel et al 2015; } \\
\text { Rooduijn and Burgoon } \\
2017\end{array}$ \\
\hline Sweden & $\begin{array}{l}\text { Sweden Democrats } \\
\text { (SD) }\end{array}$ & & $\begin{array}{l}\mathrm{R} 5, \mathrm{R} 6 \text { and } \\
\mathrm{R} 7, \mathrm{R} 8\end{array}$ & $\begin{array}{l}\text { Immerzeel et al 2015; } \\
\text { Rooduijn and Burgoon } \\
2017\end{array}$ \\
\hline Switzerland & $\begin{array}{l}\text { Swiss People's Party } \\
\text { (SVP) }\end{array}$ & & $\begin{array}{l}\text { R1, R2, R3, } \\
\text { R4, R5, R6 } \\
\text { and R7 }\end{array}$ & $\begin{array}{l}\text { Lucassen and Lubbers } \\
\text { 2012; Immerzeel et al } \\
\text { 2015; Rooduijn and } \\
\text { Burgoon } 2017\end{array}$ \\
\hline Switzerland & Swiss Democrats & & $\begin{array}{l}\text { R1, R2, R3, } \\
\text { R4, R5, R6 } \\
\text { and R7 }\end{array}$ & $\begin{array}{l}\text { Lucassen and Lubbers } \\
2012 \text {; Immerzeel et al } \\
2015\end{array}$ \\
\hline $\begin{array}{l}\text { United } \\
\text { Kingdom }\end{array}$ & $\begin{array}{l}\text { United Kingdom } \\
\text { Independence Party } \\
\text { (UKIP) }\end{array}$ & & $\begin{array}{l}\text { R3 and R7, } \\
\text { R8 }\end{array}$ & $\begin{array}{l}\text { Immerzeel et. Al 2015; } \\
\text { Rooduijn and Burgoon } \\
2017\end{array}$ \\
\hline United & British National Party & & R3 & Immerzeel et. Al 2015; \\
\hline
\end{tabular}



2017 


\section{Appendix 2. Descriptive information}

Table A2.1: Summary statistics

\begin{tabular}{|c|c|c|c|c|c|}
\hline Description & Mean & $\begin{array}{l}\text { Standard } \\
\text { deviation }\end{array}$ & Minimum & Maximum & $\begin{array}{l}\text { Number } \\
\text { observations }\end{array}$ \\
\hline Far right vote & 0.066635 & 0.249389 & 0 & 1 & 151948 \\
\hline Economic concerns over immigration & 5.068976 & 2.41297 & 0 & 10 & 233126 \\
\hline Cultural concerns over immigration & 4.317209 & 2.504216 & 0 & 10 & 233606 \\
\hline $\begin{array}{l}\text { Strict economic concerns over } \\
\text { immigration (i.e. economic concerns } \\
\text { but not cultural concerns), based on a } \\
\text { cut-off point of } 5\end{array}$ & 0.163006 & 0.369372 & 0 & 1 & 228311 \\
\hline $\begin{array}{l}\text { Strict cultural concerns over } \\
\text { immigration (i.e. cultural concerns } \\
\text { but not economic concerns), based } \\
\text { on a cut-off point of } 5\end{array}$ & 0.075932 & 0.264889 & 0 & 1 & 228311 \\
\hline $\begin{array}{l}\text { Economic and cultural concerns, } \\
\text { based on a cut-off point of } 5\end{array}$ & 0.19745 & 0.398076 & 0 & 1 & 228311 \\
\hline Male respondent & 0.470589 & 0.499135 & 0 & 1 & 242581 \\
\hline Age & 48.17545 & 18.51791 & 13 & 123 & 241941 \\
\hline Bottom income decile & 0.083542 & 0.2767 & 0 & 1 & 192622 \\
\hline Bottom half of income distribution & 0.509807 & 0.499905 & 0 & 1 & 192622 \\
\hline Education & 12.51584 & 3.857022 & 0 & 56 & 240878 \\
\hline Left-right scale & 5.100996 & 2.167993 & 0 & 10 & 215335 \\
\hline \multicolumn{6}{|l|}{$\begin{array}{l}\text { Source of income (wage is reference } \\
\text { category) }\end{array}$} \\
\hline Wage & 0.588947 & 0.492026 & 0 & 1 & 236860 \\
\hline Self employed & 0.070324 & 0.255693 & 0 & 1 & 236860 \\
\hline Pension & 0.268551 & 0.443207 & 0 & 1 & 236860 \\
\hline Unemployed & 0.018429 & 0.134496 & 0 & 1 & 236860 \\
\hline Other social benefits & 0.027746 & 0.164246 & 0 & 1 & 236860 \\
\hline Investments & 0.005184 & 0.071817 & 0 & 1 & 236860 \\
\hline Other sources & 0.011627 & 0.107201 & 2 & 1 & 236860 \\
\hline \multicolumn{6}{|l|}{$\begin{array}{l}\text { Occupation (Managers is reference } \\
\text { category) }\end{array}$} \\
\hline Manager & 0.086858 & 0.281628 & 0 & 1 & 219381 \\
\hline Professionals & 0.154266 & 0.361204 & 0 & 1 & 219381 \\
\hline Technicians & 0.161049 & 0.367577 & 0 & 1 & 219381 \\
\hline Clerks & 0.102096 & 0.302776 & 0 & 1 & 219381 \\
\hline Service & 0.15742 & 0.364197 & 0 & 1 & 219381 \\
\hline Agriculture & 0.034324 & 0.18206 & 0 & 1 & 219381 \\
\hline Craft & 0.119659 & 0.324564 & 0 & 1 & 219381 \\
\hline Operators & 0.079072 & 0.269852 & 0 & 1 & 219381 \\
\hline Elementary & 0.105255 & 0.306883 & 0 & 1 & 219381 \\
\hline Trust in national parliament & 4.593119 & 2.557438 & 0 & 10 & 237406 \\
\hline Trust in European parliament & 4.472181 & 2.420747 & 0 & 10 & 220693 \\
\hline
\end{tabular}


Table A2.2: Correlation

\begin{tabular}{|c|c|c|c|c|c|c|c|c|c|}
\hline & Male & Age & $\begin{array}{l}\text { Bottom } \\
\text { income } \\
\text { decile }\end{array}$ & $\begin{array}{l}\text { Bottom half } \\
\text { of income } \\
\text { distribution }\end{array}$ & Education & $\begin{array}{l}\text { Left right } \\
\text { scale }\end{array}$ & Wage & Self-employed & Pension \\
\hline Male & 1 & -0.001554177 & -0.04395506 & -0.059767137 & -0.005024546 & 0.050851907 & 0.001695689 & 0.046825088 & -0.02465 \\
\hline Age & -0.001554177 & 1 & 0.058321152 & 0.160426254 & -0.256666671 & 0.041622853 & -0.534312716 & -0.055329658 & 0.681151 \\
\hline Bottom income decile & -0.04395506 & 0.058321152 & 1 & 0.28205157 & -0.125621978 & -0.032680531 & -0.206558914 & -0.014551358 & 0.10871 \\
\hline $\begin{array}{l}\text { Bottom half of income } \\
\text { distribution }\end{array}$ & -0.059767137 & 0.160426254 & 0.28205157 & 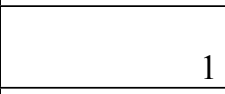 & -0.273607503 & -0.0424057 & -0.309438712 & -0.050338208 & 0.263628 \\
\hline Education & -0.005024546 & -0.256666671 & -0.125621978 & -0.273607503 & 1 & -0.046243881 & 0.237174731 & 0.033265851 & -0.26921 \\
\hline Left-right scale & 0.050851907 & 0.041622853 & -0.032680531 & -0.0424057 & -0.046243881 & 1 & -0.03631141 & 0.053793154 & 0.030768 \\
\hline Wage & 0.001695689 & -0.534312716 & -0.206558914 & -0.309438712 & 0.237174731 & -0.03631141 & 1 & -0.329349462 & -0.73917 \\
\hline Self-employed & 0.046825088 & -0.055329658 & -0.014551358 & -0.050338208 & 0.033265851 & 0.053793154 & -0.329349462 & 1 & -0.15495 \\
\hline Pension & -0.024653346 & 0.681151036 & 0.108710235 & 0.263627633 & -0.269212011 & 0.030767751 & -0.739168226 & -0.154945548 & 1 \\
\hline Unemployment benefits & 0.012767548 & -0.04616647 & 0.139902929 & 0.118164953 & -0.021931631 & -0.034673562 & -0.173583456 & -0.036386823 & -0.08166 \\
\hline Other social benefits & -0.020402168 & -0.061857098 & 0.176682698 & 0.136383599 & -0.029361007 & -0.027085576 & -0.201289865 & -0.042194682 & -0.0947 \\
\hline Investments & 0.015263921 & 0.031898122 & 0.009596782 & -0.012355475 & 0.017759243 & 0.028618253 & -0.09338185 & -0.019574843 & -0.04393 \\
\hline Other sources & -0.005478352 & -0.075587622 & 0.100355126 & 0.062851619 & 0.014178204 & -0.012793453 & -0.12038241 & -0.025234741 & -0.05664 \\
\hline Manager & 0.115409488 & 0.059706198 & -0.044046589 & -0.111824712 & 0.108213194 & 0.065295221 & -0.033795838 & 0.086977017 & 0.004828 \\
\hline Professionals & -0.03258563 & -0.01867431 & -0.072519282 & -0.167169333 & 0.413130809 & -0.043735202 & 0.078826935 & 0.000160907 & -0.05703 \\
\hline Technicians & -0.043812381 & -0.022542183 & -0.057372945 & -0.089195026 & 0.097059988 & -0.003683666 & 0.068832076 & -0.030478504 & -0.03753 \\
\hline Clerks & -0.149648944 & 0.004835527 & -0.018504063 & 0.013095725 & -0.037105025 & -0.003898032 & 0.003961907 & -0.040815628 & 0.015578 \\
\hline Service & -0.187920892 & -0.088537356 & 0.039395859 & 0.072062173 & -0.101856755 & -0.012668035 & 0.009680437 & -0.018391686 & -0.02893 \\
\hline Agriculture & 0.049270952 & 0.067954583 & 0.062322577 & 0.082559315 & -0.136368752 & 0.054543232 & -0.133045416 & 0.17863038 & 0.052513 \\
\hline Craft & 0.246152243 & 0.009966991 & 0.017609586 & 0.081211864 & -0.162726653 & 0.004418023 & -0.020161303 & -0.006846865 & 0.023647 \\
\hline Operators & 0.14271737 & 0.040280731 & 0.026944096 & 0.076739834 & -0.162154933 & -0.007082818 & -0.019576844 & -0.040075624 & 0.040178 \\
\hline Elementary & -0.062093763 & 0.010099419 & 0.107888757 & 0.143059725 & -0.212967636 & -0.015285024 & -0.058705971 & -0.045264179 & 0.046184 \\
\hline Trust in parliament & 0.047506304 & -0.032413959 & -0.104413849 & -0.169415568 & 0.161737321 & 0.070668061 & 0.06963178 & -0.001513065 & -0.05872 \\
\hline $\begin{array}{l}\text { Trust in European } \\
\text { parliament }\end{array}$ & -0.042213294 & -0.109156207 & -0.040003385 & -0.083620463 & 0.109094451 & 0.032394747 & 0.068395907 & 0.002120255 & -0.0651 \\
\hline
\end{tabular}




\begin{tabular}{|c|c|c|c|c|c|c|c|c|c|}
\hline & $\begin{array}{l}\text { Unemployment } \\
\text { benefits }\end{array}$ & $\begin{array}{l}\begin{array}{l}\text { Social } \\
\text { benefits }\end{array} \\
\end{array}$ & Investments & $\begin{array}{l}\begin{array}{l}\text { Other } \\
\text { sources }\end{array} \\
\end{array}$ & Manager & Professionals & Technicians & Clerks & Service \\
\hline Male & 0.012767548 & -0.020402168 & 0.015263921 & -0.005478352 & 0.115409488 & -0.03258563 & -0.043812381 & -0.149648944 & -0.18792 \\
\hline Age & 0.04616647 & -0.061857098 & 0.031898122 & -0.075587622 & 0.059706198 & -0.01867431 & -0.022542183 & 0.004835527 & -0.08854 \\
\hline Bottom income decile & 139902929 & .176682698 & 0.009596782 & 0.100355126 & -0.044046589 & -0.072519282 & -0.057372945 & -0.018504063 & 0.039396 \\
\hline $\begin{array}{l}\text { Bottom } \\
\text { distrib }\end{array}$ & 0.118164953 & 0.136383599 & -0.012355475 & 0.062851619 & -0.111824712 & -0.167169333 & -0.089195026 & 0.013095725 & 0.072062 \\
\hline Education & -0.021931631 & -0.029361007 & 0.017759243 & 0.014178204 & 0.108213194 & 0.413130809 & 0.097059988 & -0.037105025 & -0.10186 \\
\hline Left-right scale & -0.034673562 & -0.027085576 & 0.028618253 & -0.012793453 & 0.065295221 & -0.043735202 & -0.003683666 & -0.003898032 & -0.01267 \\
\hline Wage & -0.173583456 & -0.201289865 & -0.09338185 & -0.12038241 & -0.033795838 & 0.078826935 & 0.068832076 & 0.003961907 & 0.00968 \\
\hline Self-emplc & -0.036386823 & -0.042194682 & -0.019574843 & -0.025234741 & 0.086977017 & 0.000160907 & -0.030478504 & -0.040815628 & -0.01839 \\
\hline Pension & -0.081663967 & -0.094698708 & -0.043932368 & -0.056635035 & 0.00482754 & -0.057025568 & -0.037534901 & 0.01557841 & -0.02893 \\
\hline Unemployment benefits & 1 & -0.022238685 & -0.01031691 & -0.013299956 & -0.026691029 & -0.034288719 & -0.021955364 & -0.00259852 & 0.016798 \\
\hline Other social benefits & -0.022238685 & 1 & -0.011963637 & -0.01542282 & -0.027481012 & -0.039457392 & -0.026563735 & 0.00319464 & 0.040124 \\
\hline Investments & -0.01031691 & -0.011963637 & 1 & -0.007154913 & 0.037423719 & 0.001989039 & -0.001900584 & -0.001580631 & -0.00521 \\
\hline Other so & -0.013299956 & -0.01542282 & -0.007154913 & 1 & -0.012911656 & -0.011491285 & -0.011800319 & 0.005828314 & 0.032784 \\
\hline Manager & -0.026691029 & -0.027481012 & 0.037423719 & -0.012911656 & 00 & -0.149102889 & -0.149388773 & -0.108431265 & -0.13586 \\
\hline Professionals & -0.034288719 & -0.039457392 & 0.001989039 & -0.011491285 & -0.149102889 & 1 & -0.211048698 & -0.153186059 & -0.19193 \\
\hline Technicians & -0.021955364 & -0.026563735 & -0.001900584 & -0.011800319 & -0.149388773 & -0.211048698 & 1 & -0.153479772 & -0.1923 \\
\hline Clerks & -0.00259852 & 0.00319464 & -0.001580631 & 0.005828314 & -0.108431265 & -0.153186059 & -0.153479772 & 1 & -0.13958 \\
\hline Service & 0.016798056 & 0.040123813 & -0.00521172 & 0.032783861 & -0.135855547 & -0.19192966 & -0.192297659 & -0.13957594 & \\
\hline Agriculture & -0.002840435 & -0.009268888 & 0.004446261 & -0.005240812 & -0.056735733 & -0.080153296 & -0.080306979 & -0.058289436 & -0.07303 \\
\hline Craft & 0.015676963 & 0.001709439 & -0.008301438 & -0.01032651 & -0.117089057 & -0.165417338 & -0.165734503 & -0.120295531 & -0.15072 \\
\hline Operators & 0.018153513 & 0.00539034 & -0.012005761 & -0.007180573 & -0.09244953 & -0.130607894 & -0.130858316 & -0.094981253 & -0.119 \\
\hline Elementary & 0.051966689 & 0.06189104 & -0.012904157 & 0.018702147 & -0.100559314 & -0.142064976 & -0.142337365 & -0.103313123 & -0.12944 \\
\hline & -0.04403692 & -0.02115806 & 0.014391637 & 0.0029725 & 0.044845604 & 0.133555192 & 0.047152064 & -0.005480607 & -0.03042 \\
\hline $\begin{array}{l}\text { Trust in Eur } \\
\text { parliament }\end{array}$ & -0.031439497 & -0.010902001 & -0.003097336 & 0.011360836 & 0.017180732 & 0.081869775 & 0.020175294 & 0.002084439 & -0.00536 \\
\hline
\end{tabular}




\begin{tabular}{|c|c|c|c|c|c|c|}
\hline & Agriculture & Craft & Operators & Elementary & Trust in parliament & Trust in European parliament \\
\hline Male & 0.049270952 & 0.246152243 & 0.14271737 & -0.062093763 & 0.047506304 & -0.042213294 \\
\hline Age & 0.067954583 & 0.009966991 & 0.040280731 & 0.010099419 & -0.032413959 & -0.109156207 \\
\hline Bottom income decile & 0.062322577 & 0.017609586 & 0.026944096 & 0.107888757 & -0.104413849 & -0.040003385 \\
\hline $\begin{array}{l}\text { Bottom half of income } \\
\text { distribution }\end{array}$ & 0.082559315 & 0.081211864 & 0.076739834 & 0.143059725 & -0.169415568 & -0.083620463 \\
\hline Education & -0.136368752 & -0.162726653 & -0.162154933 & -0.212967636 & 0.161737321 & 0.109094451 \\
\hline Left-right scale & 0.054543232 & 0.004418023 & -0.007082818 & -0.015285024 & 0.070668061 & 0.032394747 \\
\hline Wage & -0.133045416 & -0.020161303 & -0.019576844 & -0.058705971 & 0.06963178 & 0.068395907 \\
\hline Self-employed & 0.17863038 & -0.006846865 & -0.040075624 & -0.045264179 & -0.001513065 & 0.002120255 \\
\hline Pension & 0.05251256 & 0.023647119 & 0.040178141 & 0.046184398 & -0.058723379 & -0.065101218 \\
\hline Unemployment benefits & -0.002840435 & 0.015676963 & 0.018153513 & 0.051966689 & -0.04403692 & -0.031439497 \\
\hline Other social benefits & -0.009268888 & 0.001709439 & 0.00539034 & 0.06189104 & -0.02115806 & -0.010902001 \\
\hline Investments & 0.004446261 & -0.008301438 & -0.012005761 & -0.012904157 & 0.014391637 & -0.003097336 \\
\hline Other sources & -0.005240812 & -0.01032651 & -0.007180573 & 0.018702147 & 0.0029725 & 0.011360836 \\
\hline Manager & -0.056735733 & -0.117089057 & -0.09244953 & -0.100559314 & 0.044845604 & 0.017180732 \\
\hline Professionals & -0.080153296 & -0.165417338 & -0.130607894 & -0.142064976 & 0.133555192 & 0.081869775 \\
\hline Technicians & -0.080306979 & -0.165734503 & -0.130858316 & -0.142337365 & 0.047152064 & 0.020175294 \\
\hline Clerks & -0.058289436 & -0.120295531 & -0.094981253 & -0.103313123 & -0.005480607 & 0.002084439 \\
\hline Service & -0.073031917 & -0.150720507 & -0.119003777 & -0.129442932 & -0.030421544 & -0.005359406 \\
\hline Agriculture & 1 & -0.062943608 & -0.049698128 & -0.054057708 & -0.01235562 & -0.017212991 \\
\hline Craft & -0.062943608 & 1 & -0.102565116 & -0.111562252 & -0.068932808 & -0.048539504 \\
\hline Operators & -0.049698128 & -0.102565116 & 1 & -0.088085753 & -0.079148034 & -0.052933788 \\
\hline Elementary & -0.054057708 & -0.111562252 & -0.088085753 & 1 & -0.08607948 & -0.035851131 \\
\hline Trust in parliament & -0.01235562 & -0.068932808 & -0.079148034 & -0.08607948 & 1 & 0.520312072 \\
\hline $\begin{array}{l}\text { Trust in European } \\
\text { parliament }\end{array}$ & -0.017212991 & -0.048539504 & -0.052933788 & -0.035851131 & 0.520312072 & \\
\hline
\end{tabular}


Figure A2.1: Distribution of cultural concerns

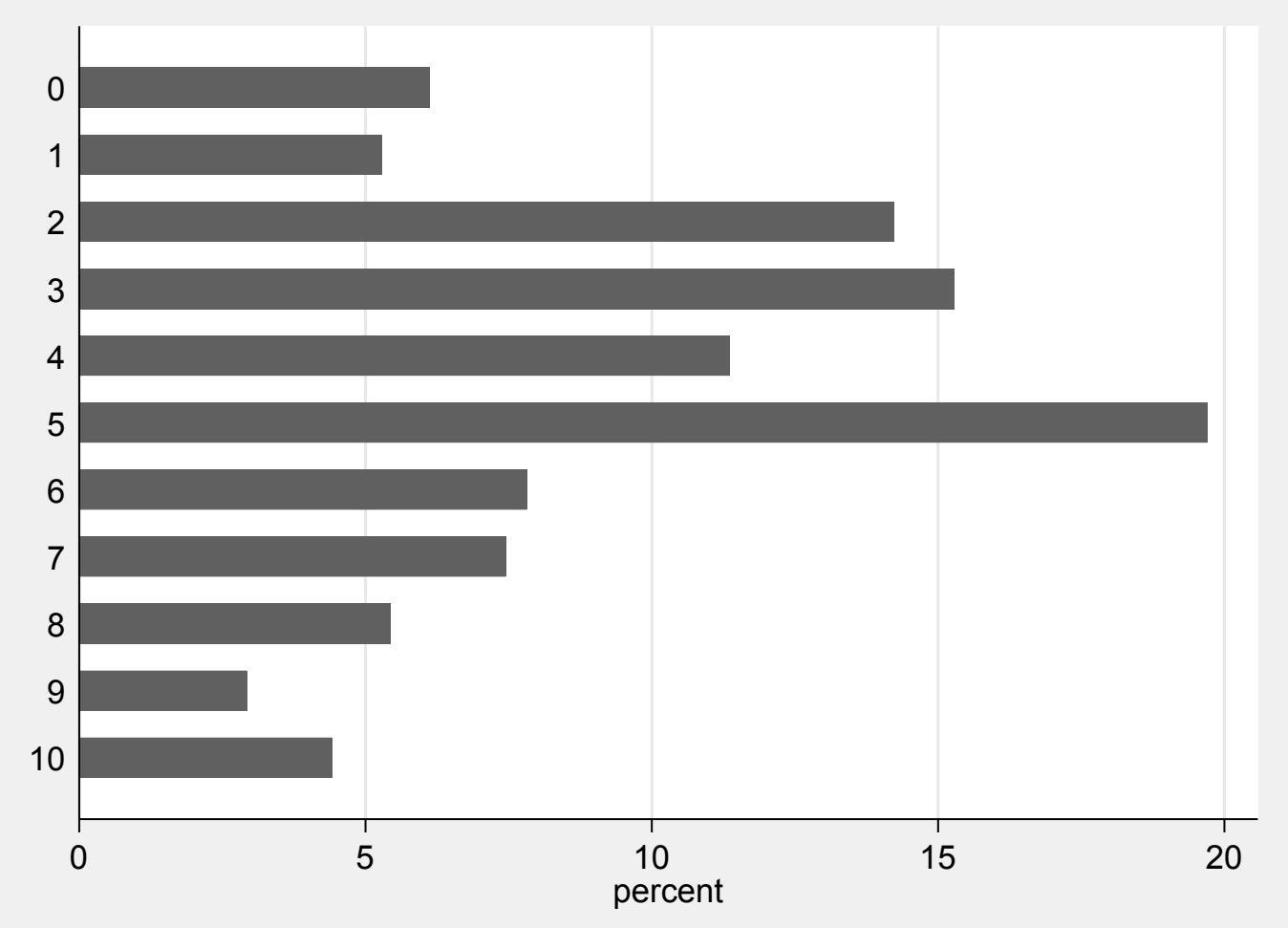

Figure A2.2: Distribution of economic concerns

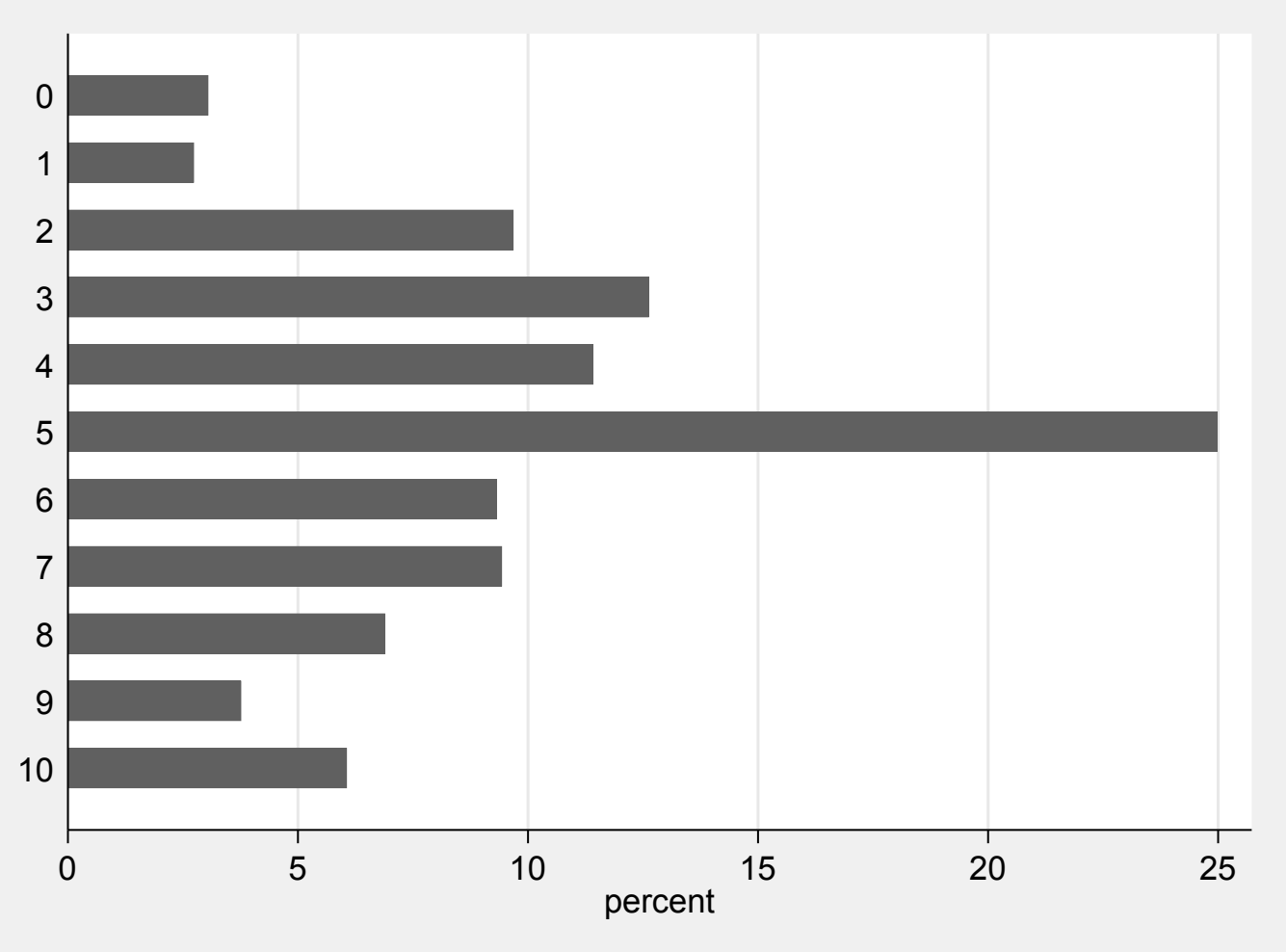


Figure A2.3: Percentage of far right voters in the entire electorate and among those with cultural concerns
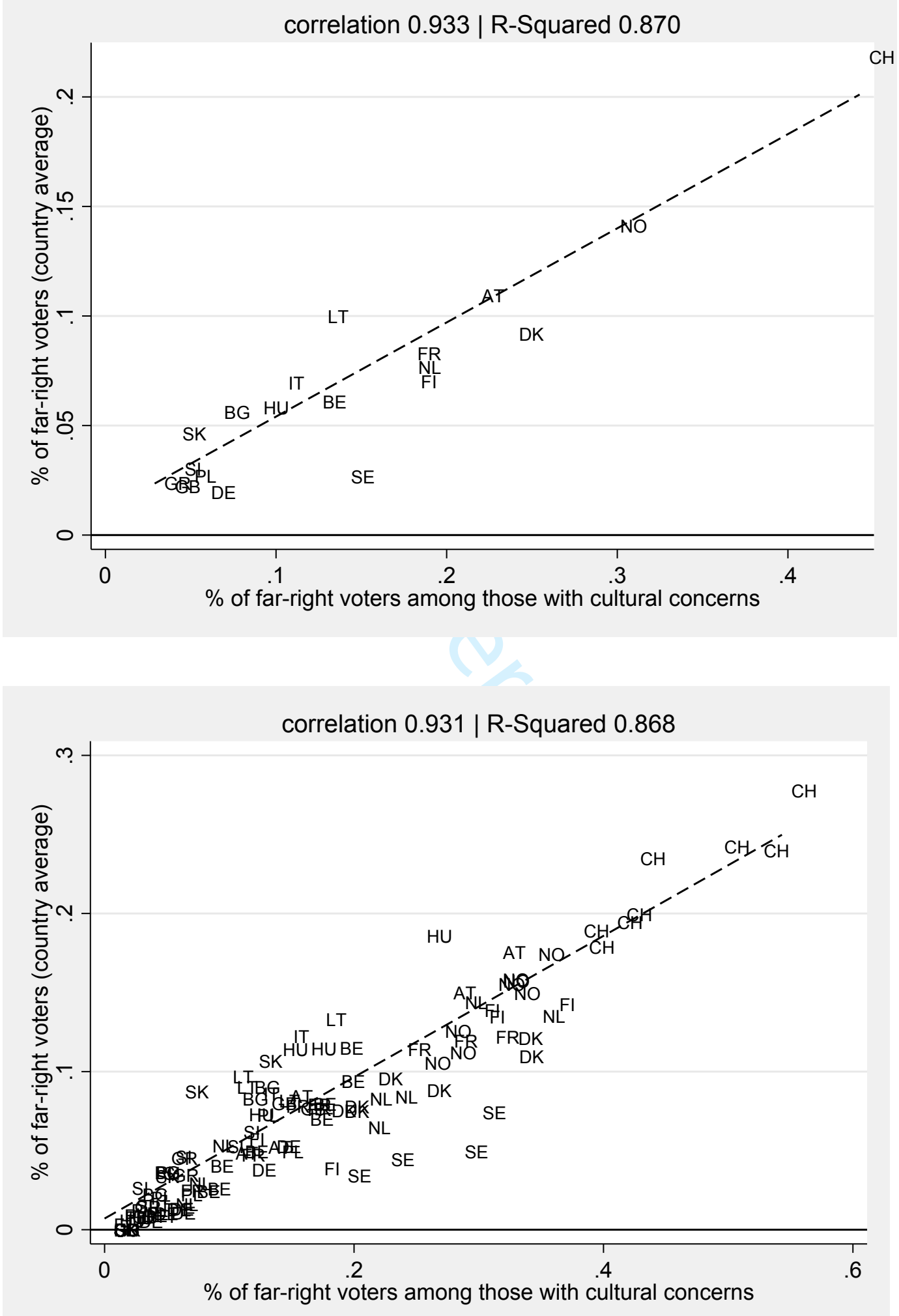
Figure A2.4: Percentage of far right voters in the entire electorate and among those with economic concerns
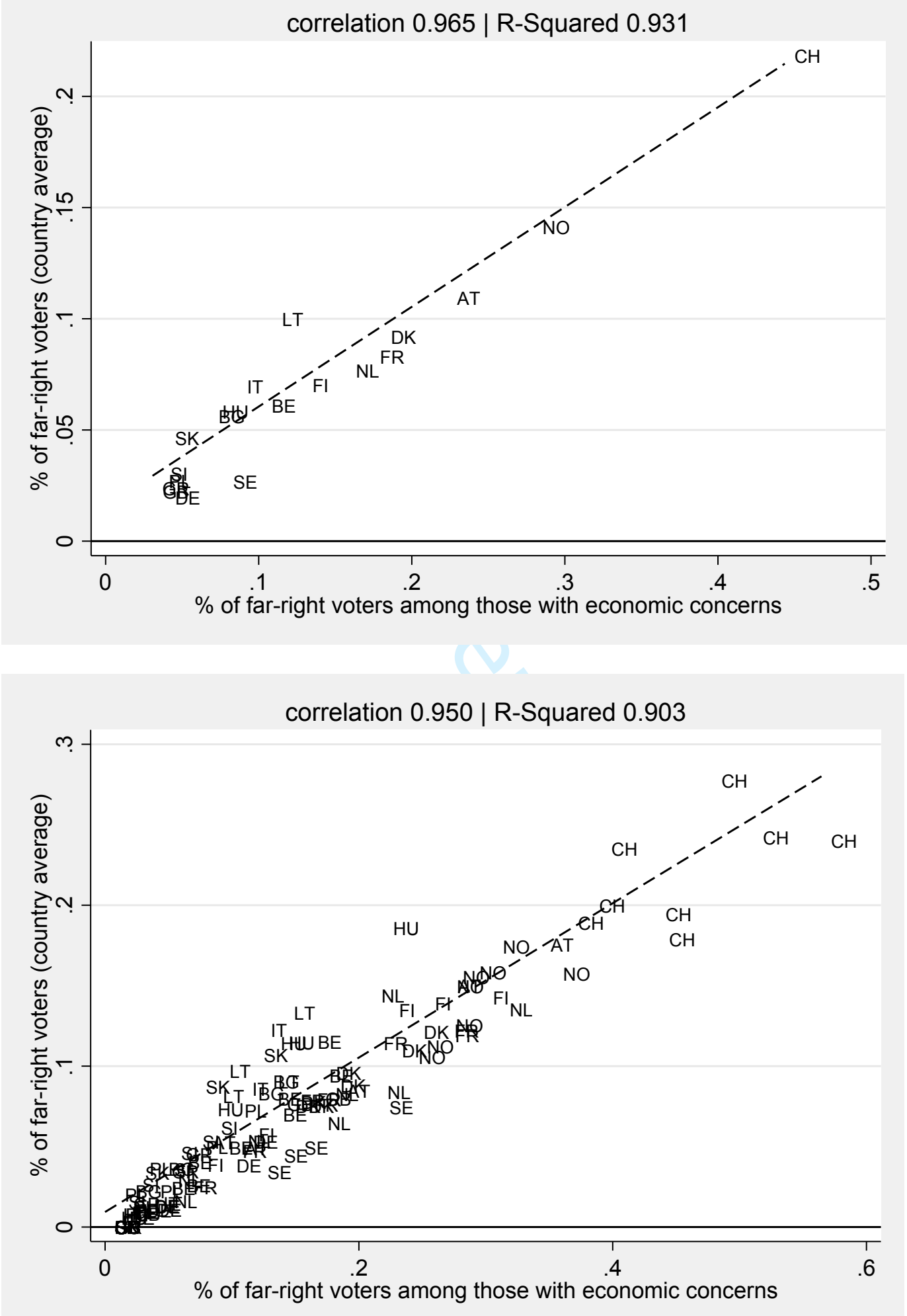
Figure A2.5: Percentage of far right voters in the entire electorate versus percentage of far right voters with economic concerns (left hand side) and percentage of far right voters with cultural concerns (right hand side)
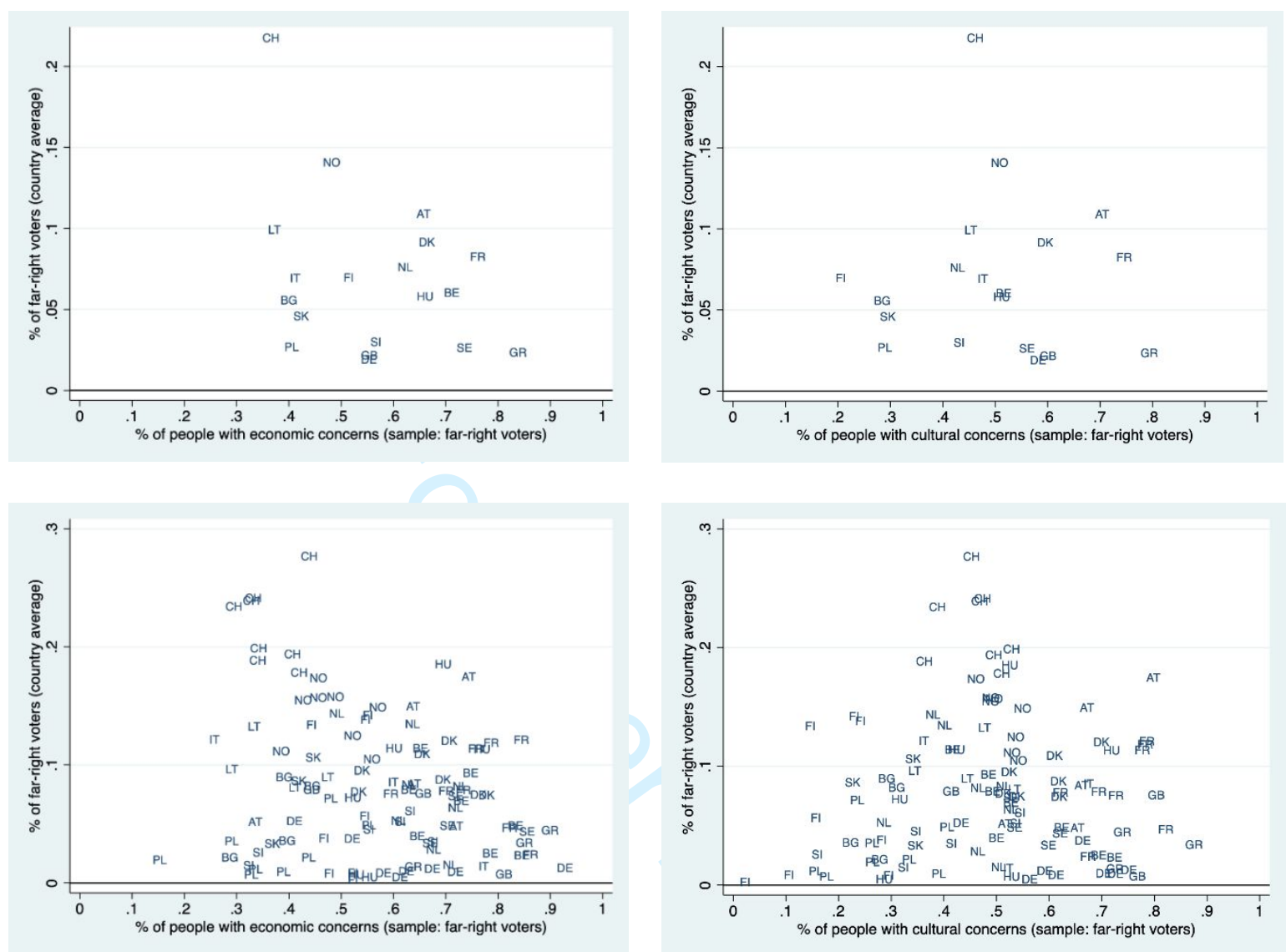
Figure A2.6: Number of far right and non-far right voters with different levels of cultural concerns

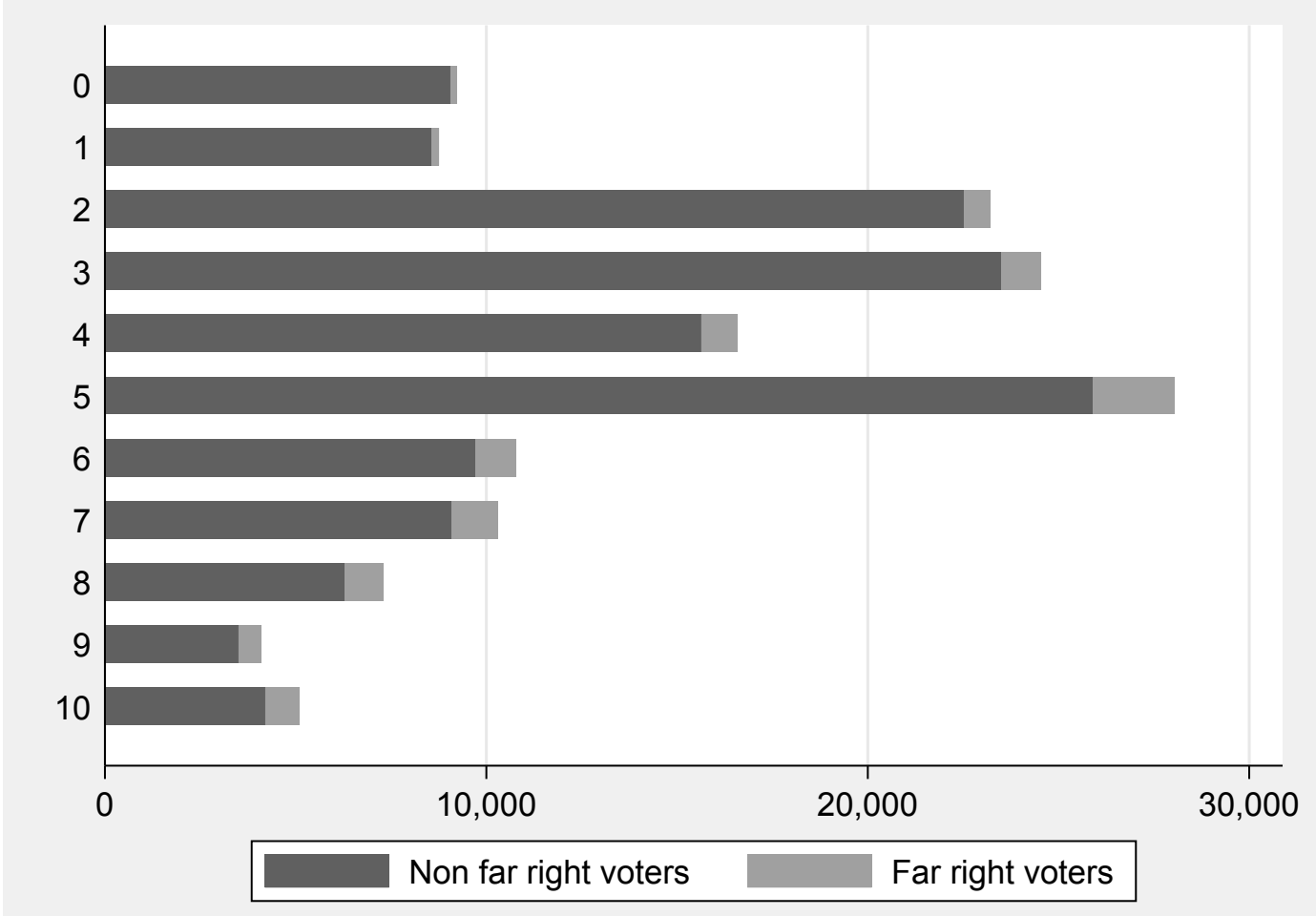

Figure A2.7: Number of far right and non-far right voters with different levels of economic concerns

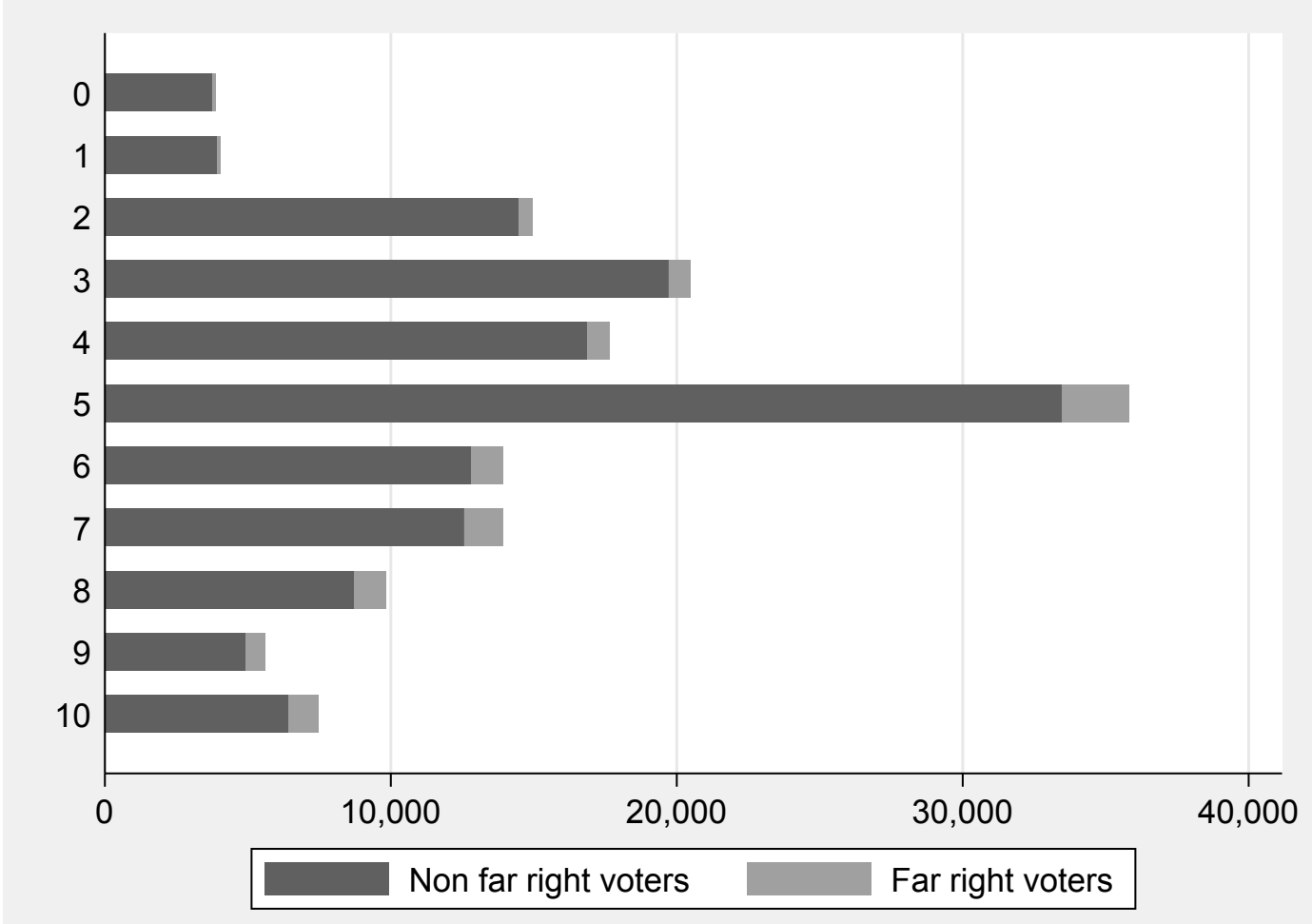


Table A2.3. Far right voters with economic and cultural concerns

\begin{tabular}{|c|c|c|}
\hline $\begin{array}{l}\text { Economic concerns over } \\
\text { immigration }\end{array}$ & Did not vote for far right & Voted for far right \\
\hline 0 & 4,353 & 86 \\
\hline 1 & 4,112 & 88 \\
\hline 2 & 15,341 & 309 \\
\hline 3 & 19,781 & 444 \\
\hline 4 & 17,603 & 497 \\
\hline 5 & 34,539 & 1,590 \\
\hline 6 & 12,649 & 758 \\
\hline 7 & 12,398 & 995 \\
\hline 8 & 8,709 & 843 \\
\hline 9 & 4,522 & 535 \\
\hline 10 & 6,372 & 1,051 \\
\hline $\begin{array}{l}\text { Cultural concerns over } \\
\text { immigration }\end{array}$ & Did not vote for far right & Voted for far right \\
\hline 0 & 9244.145 & 124.3178 \\
\hline 1 & 8200.76 & 111.2039 \\
\hline 2 & 22216.06 & 431.5777 \\
\hline 3 & 23570.52 & 619.6374 \\
\hline 4 & $\begin{array}{r}16377.33 \\
\end{array}$ & 581.1398 \\
\hline 5 & 26111.18 & 1423.463 \\
\hline 6 & 10368.34 & 738.9172 \\
\hline 7 & 9595.537 & 846.3265 \\
\hline 8 & 6817.179 & 852.3091 \\
\hline 9 & 3514.269 & 502.4339 \\
\hline 10 & 4661.552 & 985.8045 \\
\hline
\end{tabular}


Figure A2.8. Distribution of concerns among far right voters (cut-off point of 5)

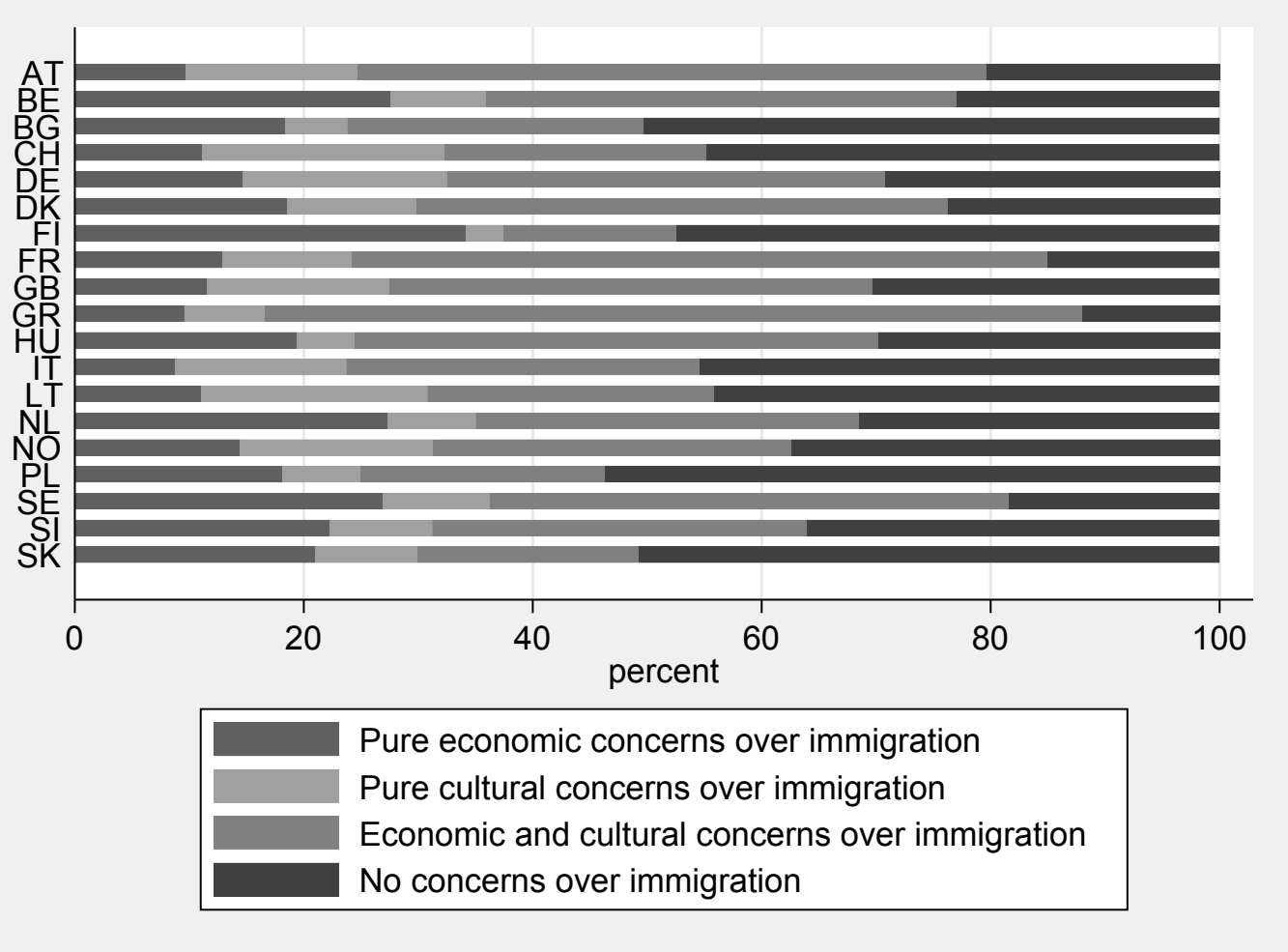

Figure A2.9. Distribution of concerns among far right voters (cut-off point of 7)

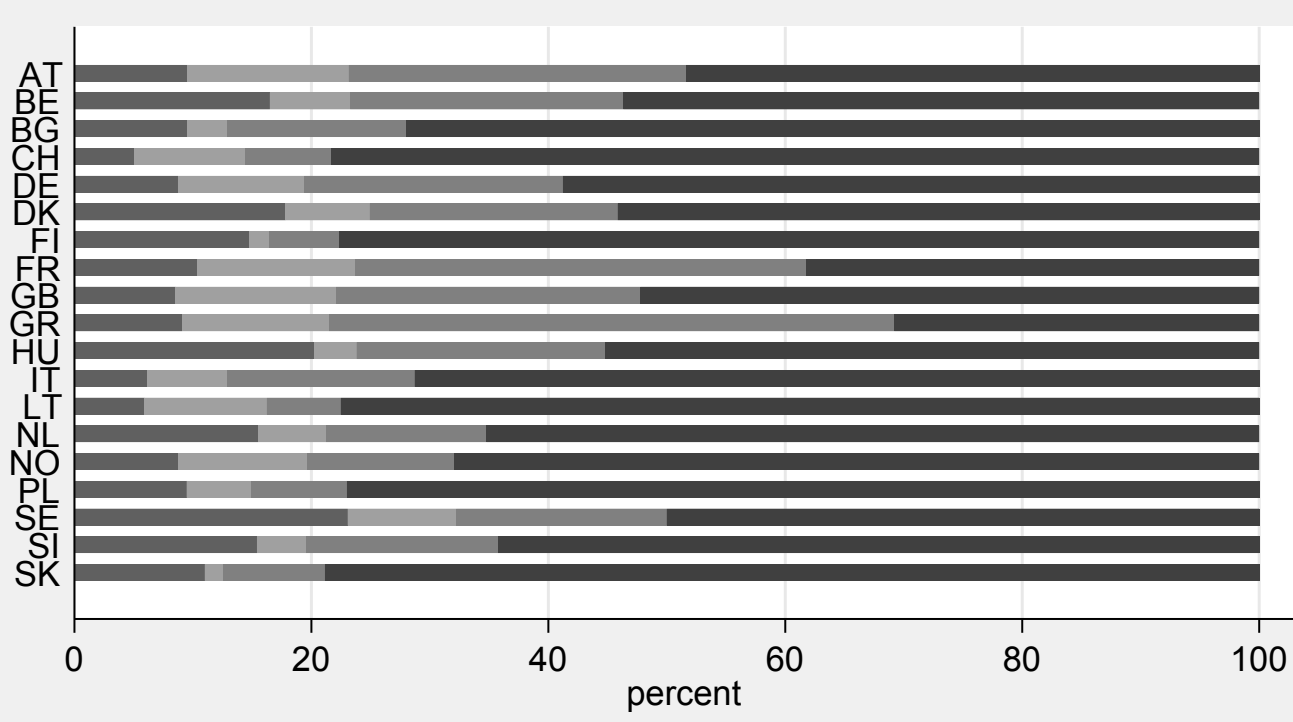

\begin{tabular}{|l}
\hline Pure economic concerns over immigration \\
Pure cultural concerns over immigration \\
Economic and cultural concerns over immigration \\
No concerns over immigration
\end{tabular}


Figure A2.10. Percentage of far right voters overall when manipulating the numbers of voters with different immigration concerns (cut-off point of 5)

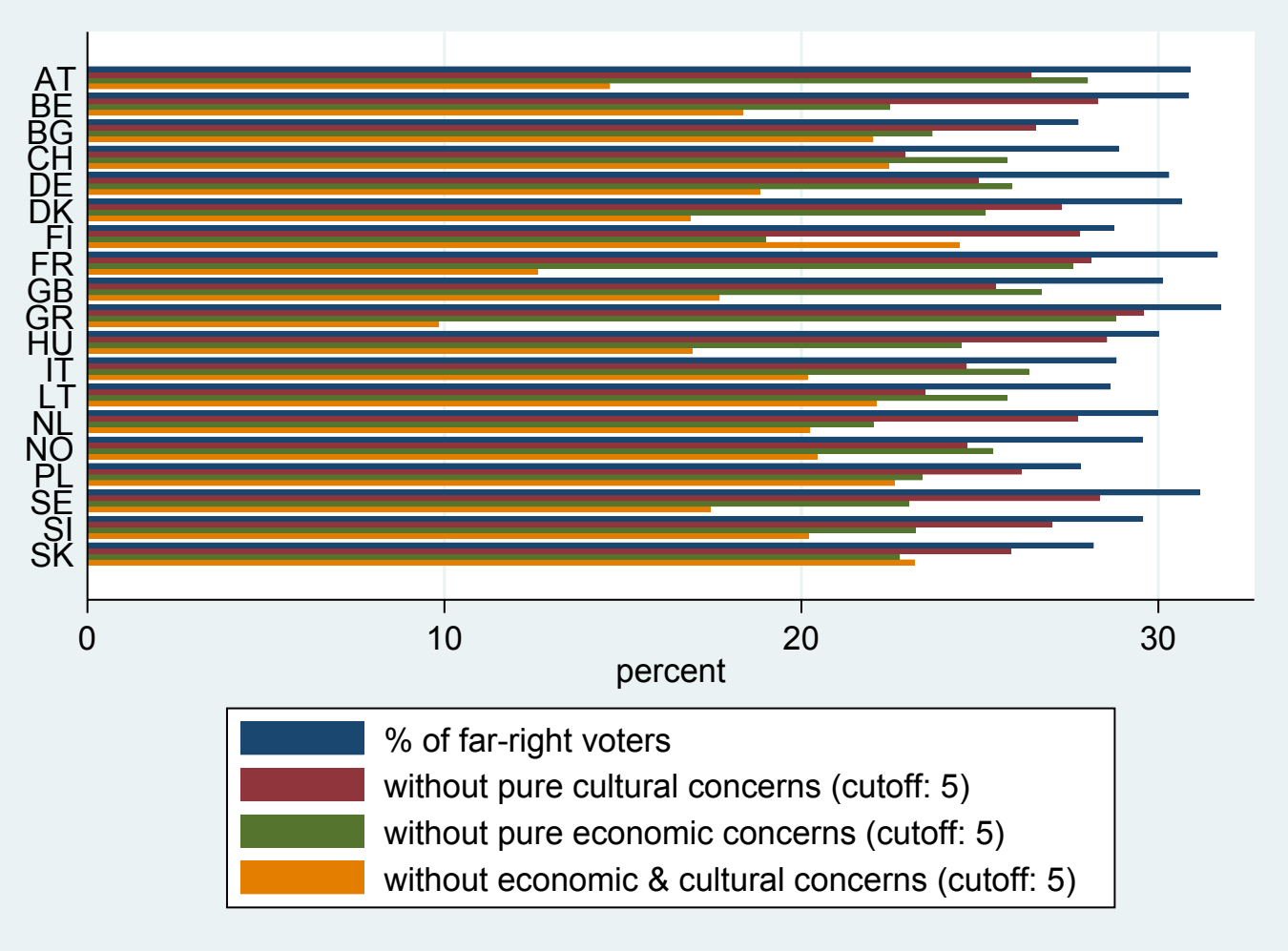

Figure A2.11. Percentage of far right voters overall when manipulating the numbers of voters with different immigration concerns (cut-off point of 7)

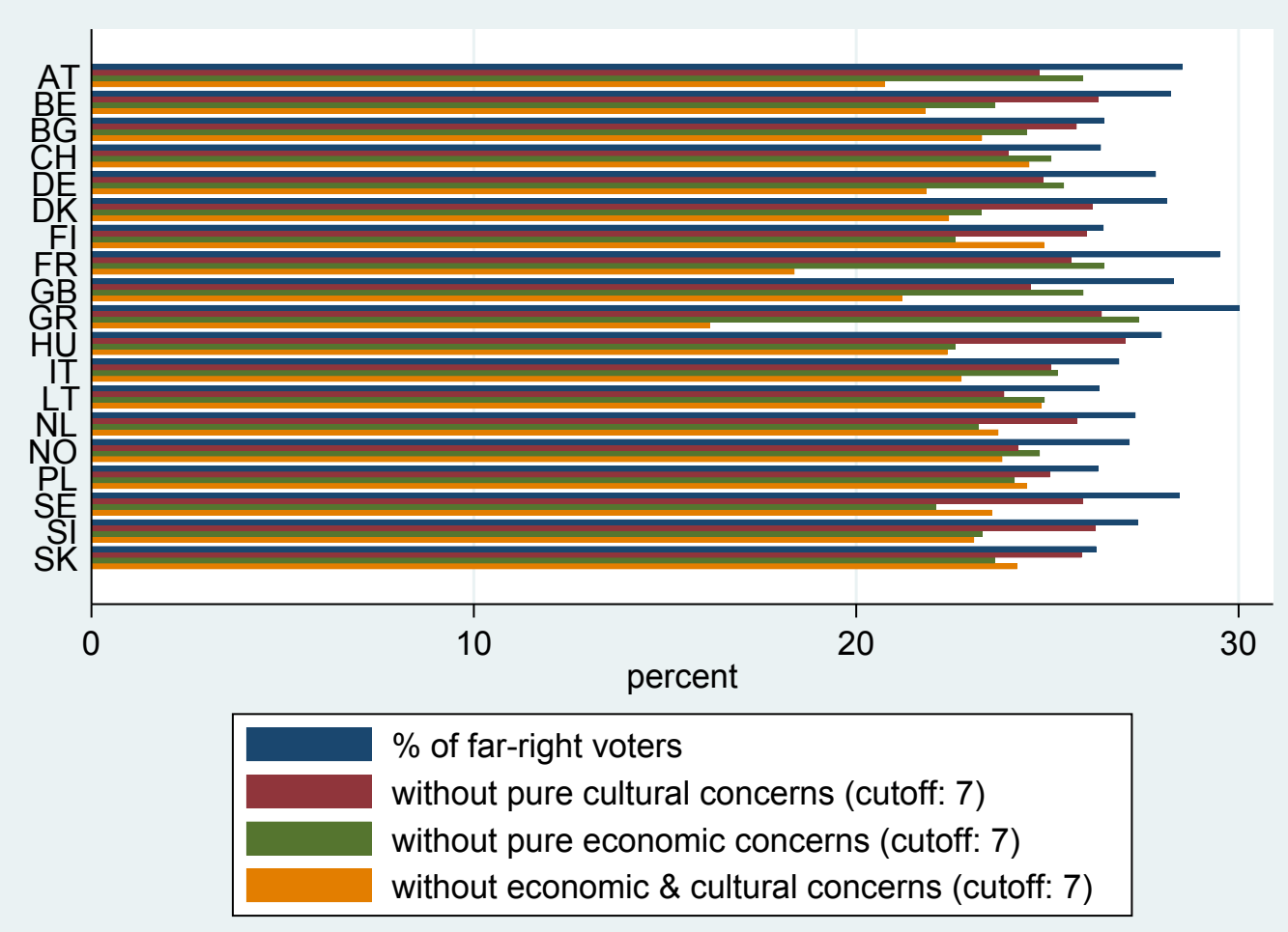


Appendix 3. Main regression tables - without PiS (starts on next page) 
Table A3.1.a. Multilevel random intercept logistic regression table - baseline without PiS

\begin{tabular}{|c|c|c|c|c|c|c|c|c|c|}
\hline Column & 1 & 2 & 3 & 4 & 5 & 6 & 7 & 8 & 9 \\
\hline Economic concerns over immigration & $0.175 * * *$ & $0.162 * * *$ & $0.164 * * *$ & $0.163 * * *$ & $0.152 * * *$ & $0.120 * * *$ & $0.114 * * *$ & $0.114 * * *$ & $0.220 * * *$ \\
\hline $\begin{array}{l}\text { Cultural concerns over immigration } \\
\text { Interaction between economic and } \\
\text { cultural concerns }\end{array}$ & $0.235 * * *$ & $0.222 * * *$ & $0.192 * * *$ & $0.192 * * *$ & $0.188^{* * *}$ & $0.161 * * *$ & $0.153 * * *$ & $0.153 * * *$ & $0.272 * * *$ \\
\hline Male & $0.480 * * *$ & $0.482 * * *$ & $0.429 * * *$ & $0.432 * * *$ & $0.390 * * *$ & $0.435 * * *$ & $0.403 * * *$ & $0.409 * * *$ & $0.411 * * *$ \\
\hline Age & $-0.011 * * *$ & $-0.016^{* * *}$ & $-0.017 * * *$ & $-0.015 * * *$ & $-0.012 * * *$ & $-0.013 * * *$ & $-0.014 * * *$ & $-0.014 * * *$ & $-0.014 * * *$ \\
\hline Bottom income dummy & 0.064 & -0.025 & 0.056 & 0.008 & -0.026 & -0.056 & -0.062 & & \\
\hline Lower half of income dummy & & & & & & & & $0.101 * * *$ & $0.104 * * *$ \\
\hline Education (in years) & & $-0.070 * * *$ & $-0.075 * * *$ & $-0.075 * * *$ & $-0.043 * * *$ & $-0.038 * * *$ & $-0.038 * * *$ & $-0.037 * * *$ & $-0.035 * * *$ \\
\hline \multicolumn{10}{|l|}{ Reference category: wages } \\
\hline Self-employed & & & & $-0.236 * * *$ & $-0.181 * * *$ & $-0.202 * * *$ & $-0.211 * * *$ & $-0.213 * * *$ & $-0.218 * * *$ \\
\hline Pensions & & & & $-0.099 * *$ & $-0.097 * *$ & $-0.095 * *$ & $-0.082 *$ & $-0.117 * * *$ & $-0.117 * * *$ \\
\hline Unemployed & & & & $0.400 * * *$ & $0.396 * * *$ & $0.366 * * *$ & $0.393 * * *$ & $0.328 * * *$ & $0.329 * * *$ \\
\hline Other social benefits & & & & $0.241 * * *$ & $0.216^{* * *}$ & $0.187 * *$ & $0.193 * *$ & 0.130 & 0.141 \\
\hline Investments & & & & -0.268 & -0.223 & -0.217 & -0.205 & -0.210 & -0.215 \\
\hline Other sources & & & & $-0.334 * *$ & $-0.309 *$ & $-0.285^{*}$ & -0.239 & $-0.294 *$ & $-0.286^{*}$ \\
\hline Placement on left-right scale & & & $0.242 * * *$ & $0.245 * * *$ & $0.254 * * *$ & $0.272 * * *$ & $0.272 * * *$ & $0.273 * * *$ & $0.271 * * *$ \\
\hline Reference category: manager & & & & & & & & & \\
\hline Professional & & & 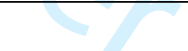 & & $-0.215 * * *$ & $-0.204 * * *$ & $-0.191 * * *$ & $-0.193 * * *$ & $-0.187 * * *$ \\
\hline Technician & & & & & $0.157 * * *$ & $0.154 * * *$ & $0.184 * * *$ & $0.178 * * *$ & $0.169 * * *$ \\
\hline Clerical & & & & & $0.329 * * *$ & $0.325 * * *$ & $0.358 * * *$ & $0.347 * * *$ & $0.335 * * *$ \\
\hline Service & & & & & $0.568 * * *$ & $0.541 * * *$ & $0.547 * * *$ & $0.530 * * *$ & $0.521 * * *$ \\
\hline Agriculture & & & & & $0.266^{* * *}$ & $0.283 * * *$ & $0.259 * * *$ & $0.226 * *$ & $0.209 * *$ \\
\hline Craft & & & & & $0.638 * * *$ & $0.587 * * *$ & $0.624 * * *$ & $0.605 * * *$ & $0.588 * * *$ \\
\hline Operator & & & & & $0.667 * * *$ & $0.603 * * *$ & $0.622 * * *$ & $0.603 * * *$ & $0.592 * * *$ \\
\hline Elementary & & & & & $0.546^{* * *}$ & $0.492 * * *$ & $0.511 * * *$ & $0.482 * * *$ & $0.470 * * *$ \\
\hline Trust in National Parliament & & & & & & $-0.188 * * *$ & $-0.140 * * *$ & $-0.139 * * *$ & $-0.139 * * *$ \\
\hline Trust in European Parliament & & & & & & & $-0.097 * * *$ & $-0.097 * * *$ & $-0.097 * * *$ \\
\hline Constant & $-5.155 * * *$ & $-3.920 * * *$ & $-5.033 * * *$ & $-5.061 * * *$ & $-5.848 * * *$ & $-4.900 * * *$ & $-4.562 * * *$ & $-4.624 * * *$ & $-5.198 * * *$ \\
\hline Observations & 124,046 & 123,674 & 119,680 & 117,971 & 113,175 & 112,730 & 106,950 & 106,950 & 106,950 \\
\hline Number of groups & 123 & 123 & 123 & 122 & 122 & 122 & 122 & 122 & 122 \\
\hline Log likelihood & -24658 & -24385 & -22731 & -22642 & -21570 & -21048 & -19864 & -19860 & -19818 \\
\hline Wald Chi2 & 5043 & 5234 & 6103 & 6125 & 6132 & 6690 & 6474 & 6478 & 6360 \\
\hline Prob > chi 2 & 0 & 0 & 0 & 0 & 0 & 0 & 0 & 0 & 0 \\
\hline
\end{tabular}

Note: this table presents the results from a multilevel mixed-effects logistic regression taking into account the hierarchical nature of the data; the standard errors are robust and clustered by country-wave. *** $p<0.01, * * p<0.05, * p<0.1$. 
Table A3.1.b. Average marginal effects for key variables of column 8 in table A3.1.a

\begin{tabular}{lc}
\hline Economic concerns over immigration & $0.00212^{* * *}$ \\
& $(0.000381)$ \\
Cultural concerns over immigration & $0.00286^{* * *}$ \\
& $(0.000496)$ \\
\hline Observations & 106,950
\end{tabular}

Note: this table presents the average marginal effects for key variables of column 8 in table A3.1.a which was carried out using a multilevel mixed-effects logistic regression taking into account the hierarchical nature of the data; the standard errors are robust and clustered by country-wave. ${ }^{* * *} p<0.01,{ }^{* *} p<0.05$, $* p<0.1$.

Figure A3.1. Predicted probabilities using column 8 of table A3.1.a

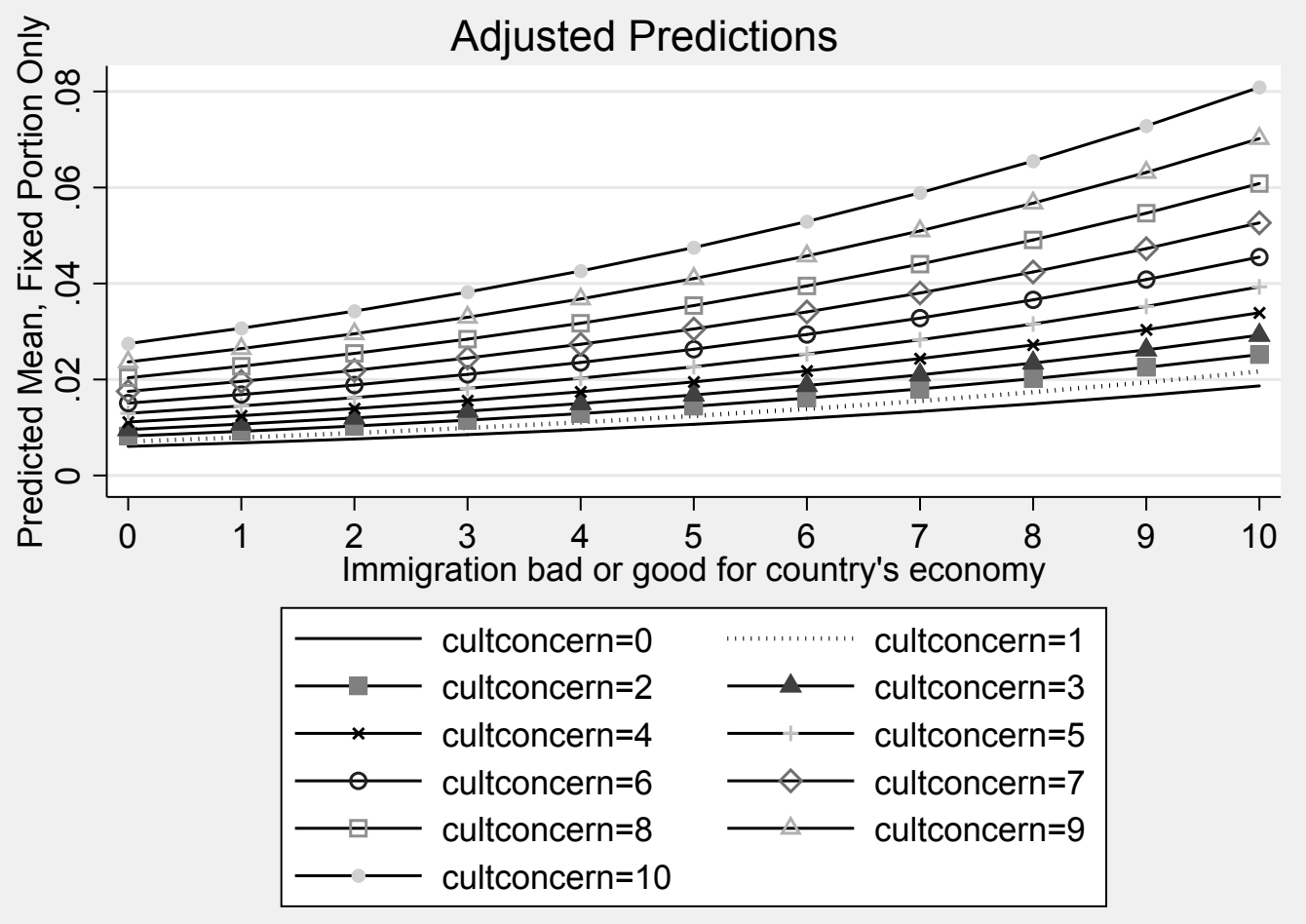


Figure A3.2. Predicted probabilities using column 9 of table A3.1.a

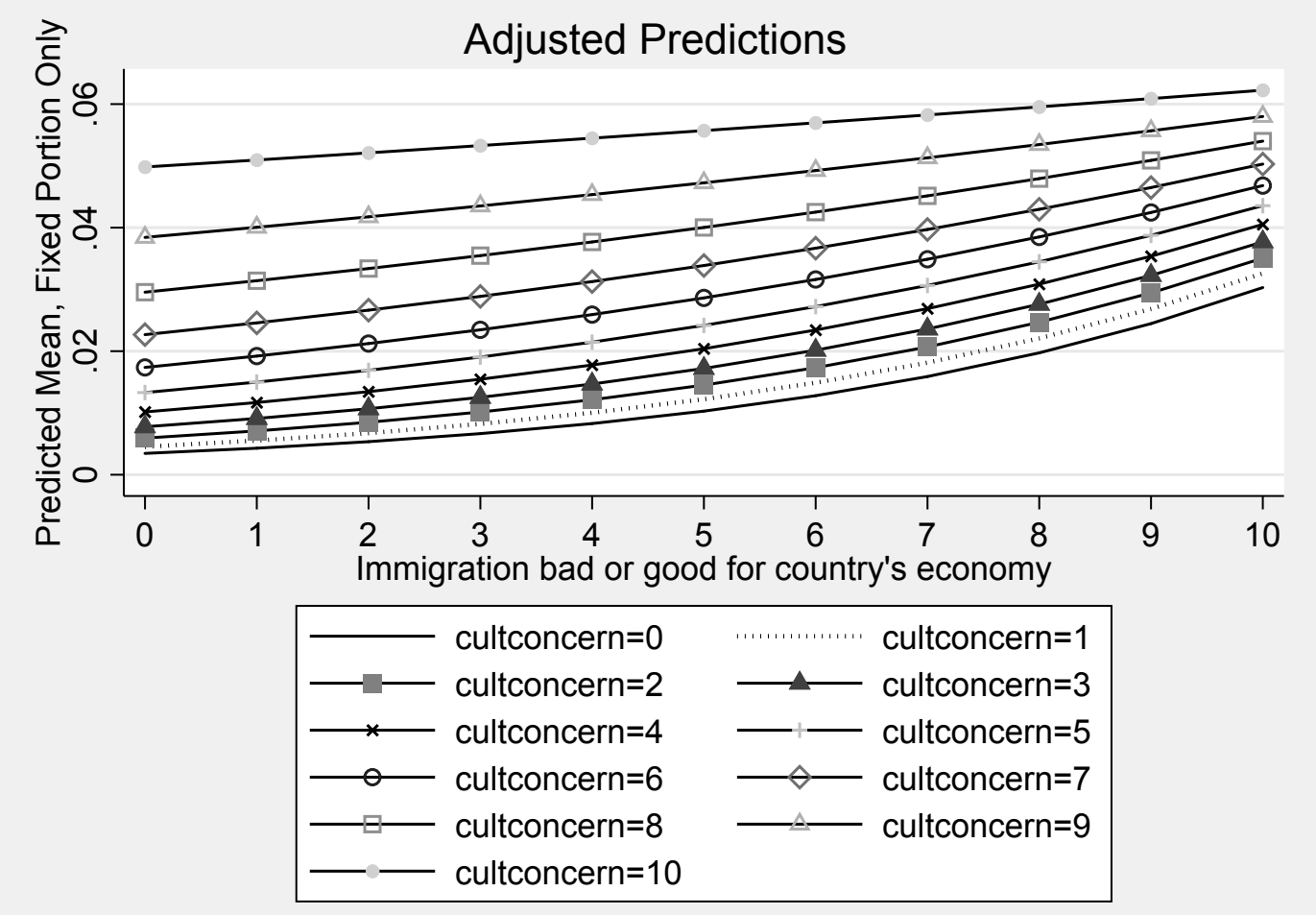


Table A3.2. Multilevel random intercept logistic regression table - baseline without PiS - different proxies for trust

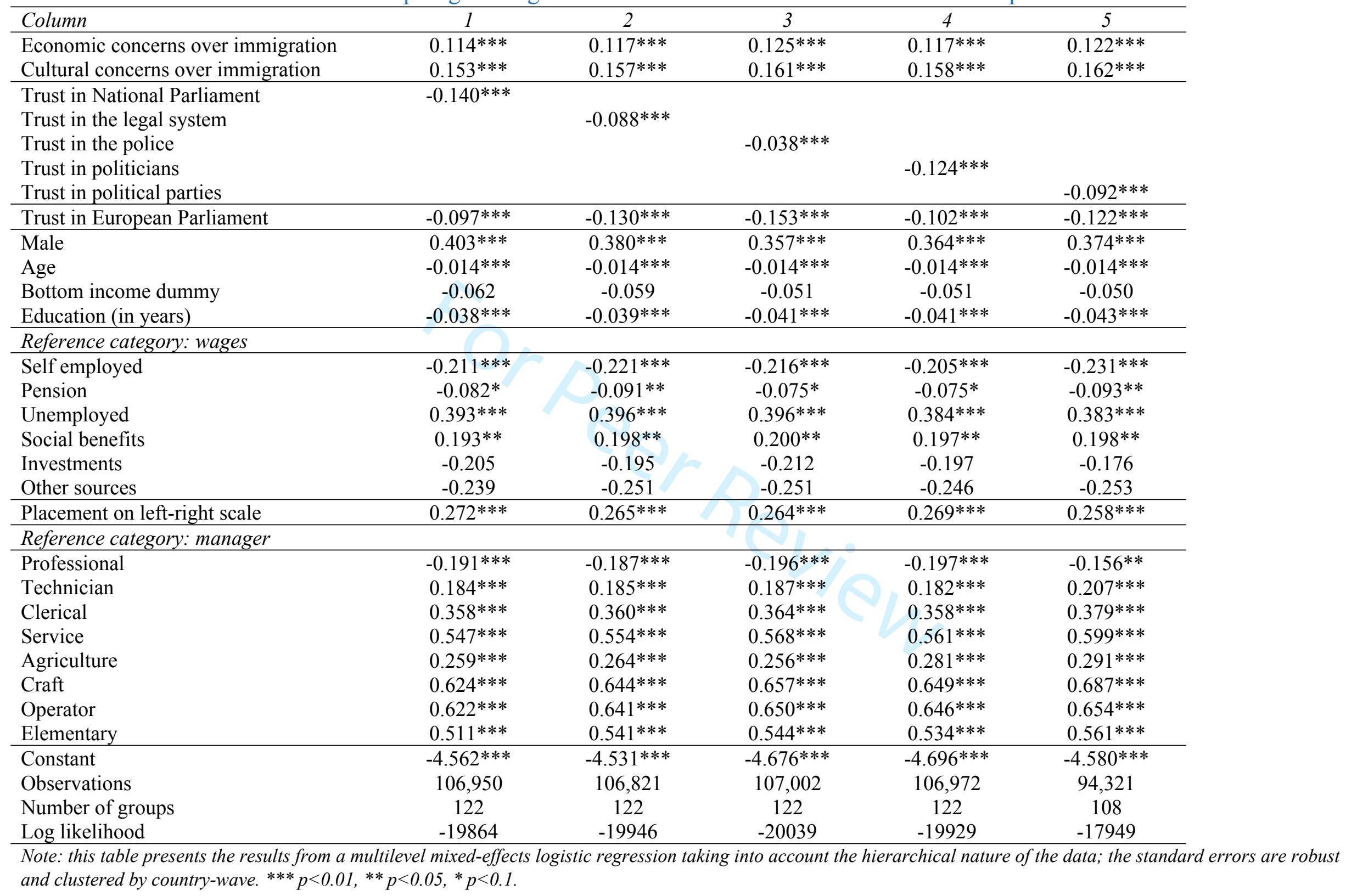


Table A3.3.a. Multilevel random intercept logistic regression table - binary concern variables without PiS

\begin{tabular}{|c|c|}
\hline Binary materialist (coded 1 if economic concerns over immigration $>5$ ) & $0.523 * * *$ \\
\hline Binary culturalist (coded 1 if cultural concerns over immigration $>5$ ) & $0.591 * * *$ \\
\hline Male & $0.405 * * *$ \\
\hline Age & $-0.014 * * *$ \\
\hline Lower half of income dummy & $0.110 * * *$ \\
\hline Education (in years) & $-0.043 * * *$ \\
\hline Placement on left-right scale & $0.286 * * *$ \\
\hline \multicolumn{2}{|l|}{ Reference category: wages } \\
\hline Self-employed & $-0.203 * * *$ \\
\hline Pensions & $-0.107 * *$ \\
\hline Unemployed & $0.361 * * *$ \\
\hline Other social benefits & 0.124 \\
\hline Investments & -0.218 \\
\hline Other sources & $-0.302 *$ \\
\hline \multicolumn{2}{|l|}{ Reference category: manager } \\
\hline Professional & $-0.203 * * *$ \\
\hline Technician & $0.197 * * *$ \\
\hline Clerical & $0.373 * * *$ \\
\hline Service & $0.562 * * *$ \\
\hline Agriculture & $0.270 * * *$ \\
\hline Craft & $0.650 * * *$ \\
\hline Operator & $0.649 * * *$ \\
\hline Elementary & $0.530 * * *$ \\
\hline Trust in National Parliament & $-0.150 * * *$ \\
\hline Trust in European Parliament & $-0.112 * * *$ \\
\hline Constant & $-3.608 * * *$ \\
\hline Observations & 106,950 \\
\hline Number of groups & 122 \\
\hline Log likelihood & -20067 \\
\hline Wald Chi2 & 6294 \\
\hline Prob $>$ chi 2 & 0 \\
\hline
\end{tabular}

Note: this table presents the results from a multilevel mixed-effects logistic regression taking into account the hierarchical nature of the data; the standard errors are robust and clustered by countrywave. $* * * p<0.01, * * p<0.05, * p<0.1$.

Table A3.3.b. Average marginal effects of key variables in Table A3.3.a

\begin{tabular}{ll}
\hline Binary materialist (coded 1 if economic concerns over immigration $>5)$ & $0.0102^{* * *}$ \\
& $(0.00179)$ \\
Binary materialist (coded 1 if cultural concerns over immigration $>5)$ & $0.0115^{* * *}$ \\
& $(0.00201)$ \\
Observations & 106,950 \\
\hline
\end{tabular}

Note: this table presents the average marginal effects for key variables of table A3.3. a which was carried out using a multilevel mixed-effects logistic regression taking into account the hierarchical nature of the data; the standard errors are robust and clustered by country-wave. $* * * p<0.01$, $p<0.05, * p<0.1$. 
Figure A3.3. Predicted probabilities using table A3.3.a

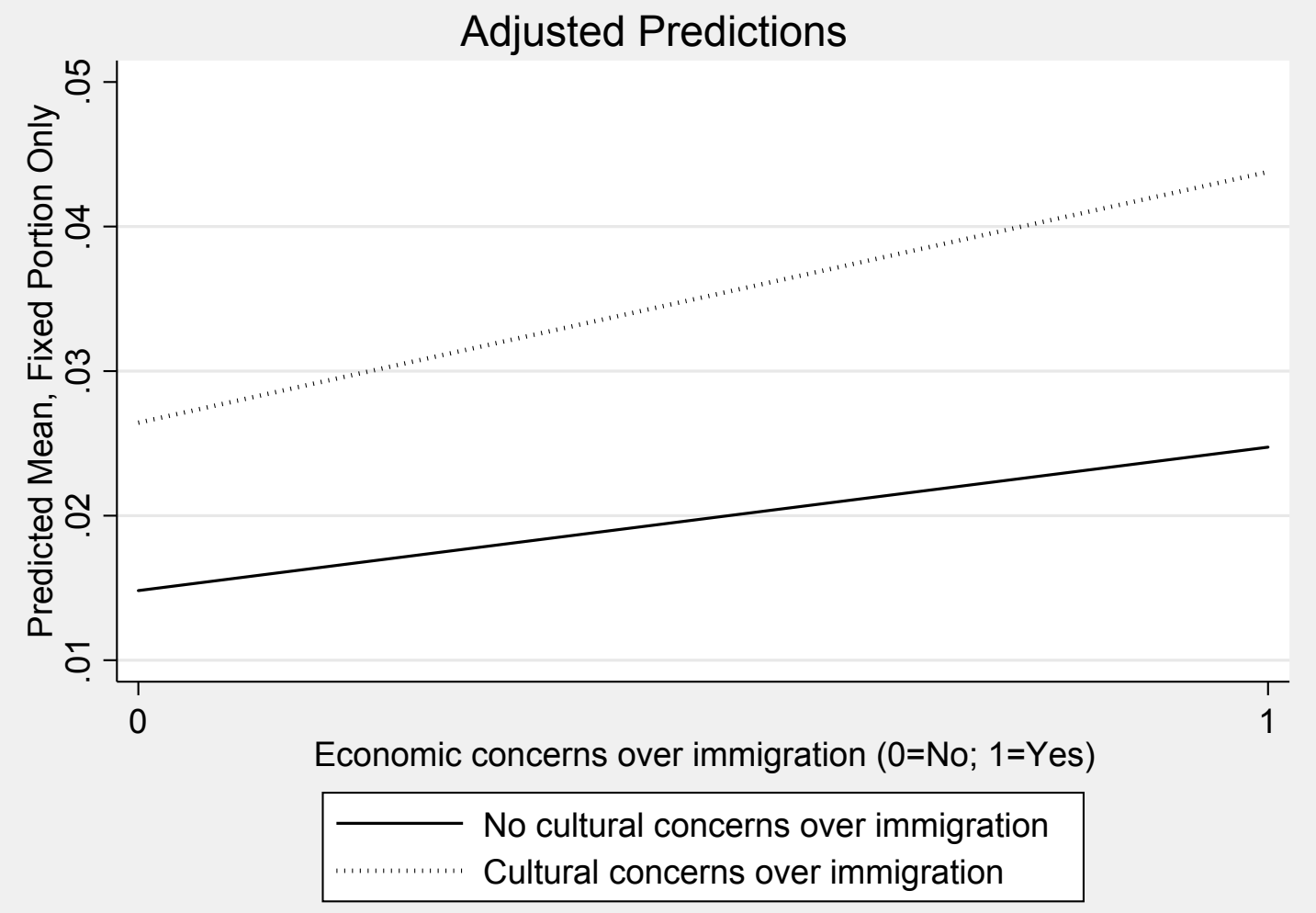


Table A3.4. Multilevel random intercept logistic regression table - binary concern variables with interaction term, without PiS

\begin{tabular}{|c|c|}
\hline Binary materialist & $0.663 * * *$ \\
\hline Binary culturalist & $0.786^{* * *}$ \\
\hline Binary materialist * Binary culturalist & $-0.352 * * *$ \\
\hline Age respondent & $-0.013 * * *$ \\
\hline Low income dummy & $0.113 * * *$ \\
\hline Education in years & $-0.042 * * *$ \\
\hline Left-right scale & $0.285 * * *$ \\
\hline \multicolumn{2}{|l|}{ Source of income (ref: wages) } \\
\hline Self-employed & $-0.204 * * *$ \\
\hline Pension & $-0.109 * *$ \\
\hline Unemployment benefits & $0.361 * * *$ \\
\hline Other social benefits & 0.125 \\
\hline Investments & -0.222 \\
\hline Other sources & $-0.306^{*}$ \\
\hline \multicolumn{2}{|l|}{ Occupation (ref: managers) } \\
\hline Professionals & $-0.199 * * *$ \\
\hline Technicians & $0.195 * * *$ \\
\hline Clerks & $0.370 * * *$ \\
\hline Service & $0.562 * * *$ \\
\hline Agriculture & $0.266^{* * *}$ \\
\hline Craft & $0.644 * * *$ \\
\hline Operators & $0.647 * * *$ \\
\hline Elementary & $0.526 * * *$ \\
\hline Trust in parliament & $-0.150 * * *$ \\
\hline Trust in European parliament & $-0.112 * * *$ \\
\hline Constant & $-3.655 * * *$ \\
\hline Observations & 106,950 \\
\hline Number of groups & 122 \\
\hline Log likelihood & -20050 \\
\hline Wald Chi2 & 6280 \\
\hline Prob $>$ chi 2 & 0 \\
\hline
\end{tabular}

Note: The table presents results from a multilevel mixed-effects logistic regression taking into account the hierarchical nature of the data. The standard errors are robust and clustered by country-wave. $* * * p<0.01, * * p<0.05, * p<0.1$. 
Figure A3.4. Predicted probabilities using table A3.4

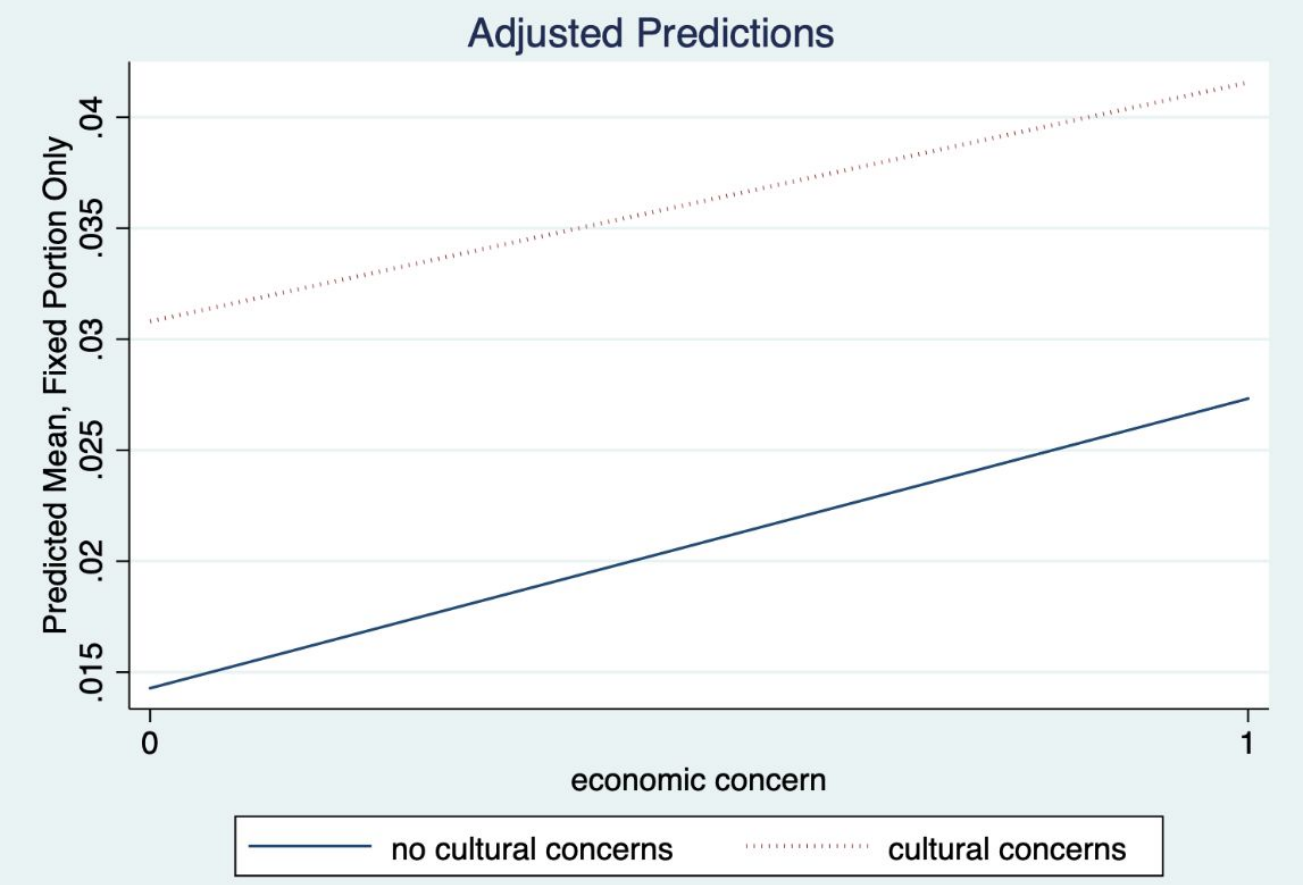


Table A3.5.a. Multilevel random intercept logistic regression table - bining concerns into four dummy variables - without PiS

Economic concerns over immigration (reference category is dummy variable equal to

1 if economic concerns equal to 0 or 1 - see notes for coding)

Economic concerns dummy variable 1

Economic concerns dummy variable 2

$-0.058$

Economic concerns dummy variable 3

$0.336^{* * *}$

$0.673^{* * *}$

Economic concerns dummy variable 4

$0.765 * * *$

Cultural concerns over immigration (reference category is dummy variable equal to

1 if cultural concerns equal to 0 or 1 - see notes for coding)

Cultural concerns dummy variable 1

Cultural concerns dummy variable 2

$0.367 * * *$

Cultural concerns dummy variable 3

$0.851 * * *$

Cultural concerns dummy variable 4

$1.191 * * *$

Male

$1.352 * * *$

Age

$0.414 * * *$

Lower half of income dummy

$-0.014 * * *$

Education (in years)

$0.102 * * *$

Placement on left-right scale

$-0.037 * * *$

Reference category: wages

$0.275 * * *$

Self-employed

$-0.217 * * *$

Pensions

$-0.115 * * *$

Unemployed

$0.326^{* * *}$

Other social benefits

0.129

Investments

$-0.209$

Other sources

$-0.291 *$

Reference category: manager

Professional

$-0.193 * * *$

Technician

$0.172 * * *$

Clerical

$0.342 * * *$

Service

$0.527 * * *$

Agriculture

$0.217 * *$

Craft

$0.601 * * *$

Operator

$0.604 * * *$

Elementary

$0.480 * * *$

Trust in national parliament

$-0.143 * * *$

Trust in European Parliament $-0.101 * * *$

Constant

Observations

106,950

Number of groups

Log likelihood

$-19875$

Wald Chi2

6367

Prob $>$ Chi2

0

Note: each type of concerns is 'binned' into five dichotomous variables: dummy variable 1 is $0 / 1 ; 2$ is 2/3, 3 is 4/5/6, 4 is 7/8 and 5 is 9/10. The table presents results from a multilevel mixed-effects logistic regression taking into account the hierarchical nature of the data. The standard errors are robust and clustered by country-wave. $* * * p<0.01, * * p<0.05, * p<0.1$. 
Table A3.5.b. Average marginal effects of key variables in Table A3.5.a

Economic concerns over immigration (reference category is dummy variable equal to 1 if economic concerns equal to 0 or 1 )

Economic concerns dummy variable 1 $-0.000783$

Economic concerns dummy variable 2

Economic concerns dummy variable 3

Economic concerns dummy variable 4

Cultural concerns over immigration (reference category is dummy variable equal to 1 if cultural concerns equal to 0 or 1 - see notes for coding)

Cultural concerns dummy variable $1 \quad 0.00442^{* * *}$

Cultural concerns dummy variable 2

Cultural concerns dummy variable 3

Culturat concems dummy variable 4

Cultural concerns dummy variable 4

Observations 106,950

Note: this table presents the average marginal effects for key variables of table A3.5. a which was carried out using a multilevel mixed-effects logistic regression taking into account the hierarchical nature of the data; the standard errors are robust and clustered by country-wave. ${ }^{* * *} p<0.01$, ** $p<0.05, * p<0.1$. 
Table A3.6: Distribution of materialists and culturalists using binary variables

\begin{tabular}{|l|l|l|}
\hline & Binary culturalist & \\
\hline Binary materialist & No (0) & Yes (1) \\
\hline No (0) & $129,335(56.65 \%)$ & $18,718(8.2 \%)$ \\
\hline Yes (1) & $34,693(15.20 \%)$ & $45,562(19.96 \%)$ \\
\hline
\end{tabular}

Note: Post-stratification design and population weights applied. The binary materialist variable is coded 1 if the respondents choose a response strictly above 5 to the question with regards to the economic impact of immigration, and 0 otherwise. Similarly, the binary culturalist variable is coded 1 if the respondents choose a response strictly above 5 to the question with regards to the cultural impact of immigration, and 0 otherwise.

Table A3.7: Distribution of far right voters among strict materialists and strict culturalists

\begin{tabular}{|l|l|l|l|l|l|}
\hline & \multicolumn{2}{|l|}{ Vote for far right } & & \multicolumn{2}{l|}{ Vote for far right } \\
\hline $\begin{array}{l}\text { Strict } \\
\text { materialists }\end{array}$ & No (0) & Yes (1) & $\begin{array}{l}\text { Strict } \\
\text { culturalists }\end{array}$ & No (0) & Yes (1) \\
\hline No (0) & 118,174 & 5,969 & No (0) & 127,292 & 6,209 \\
& $(95.2 \%)$ & $(4.8 \%)$ & & $(95.3 \%)$ & $(4.7 \%)$ \\
\hline Yes (1) & 19,933 & 1,133 & Yes (1) & 10,815 & 894 \\
& $(94.6 \%)$ & $(5.4 \%)$ & & $(92.4 \%)$ & $(7.6 \%)$ \\
\hline
\end{tabular}

Note: post-stratification, design and population weights applied. Although being a strict culturalist, as opposed to a non-strict culturalist, results in a larger increase in the predicted probability of voting for the far right than being a strict materialist, as opposed to a non-strict materialist, the number of far right voters that are strict materialists is greater than the number of far right voters that are strict culturalists.

\section{Table A3.8. Relationship between individual level coefficients and votes for far right parties at the country-wave level}

\begin{tabular}{lccc}
\hline Column & $(1)$ & $(2)$ & $(3)$ \\
\hline Variable is composed of the country-wave logistic & & & $0.08572^{* * *}$ \\
regression specific coefficient of economic concerns & $0.07972^{* * *}$ & & \\
Variable is composed of the country-wave logistic & & & 0.01528 \\
regression specific coefficient of cultural concerns & & 0.03806 \\
\hline Constant & 108 & 108 & 108 \\
Observations & 0.05 & 0.00 & 0.05 \\
R-squared & & & \\
\hline
\end{tabular}

Notes: Robust standard errors in parentheses, ${ }^{* * *} p<0.01,{ }^{* *} p<0.05, * p<0.1$. This regression is run using a country-wave level dataset. The dependent variable is the country-wave average far right party success. The two independent variables are coefficients from the respective country-wave logistic regression of individual far right party votes on economic and cultural concerns, with a series of individual level controls. Thus, each coefficient captures the size of the impact of having economic and cultural concerns, respectively, on the probability of voting for the far right in that specific country-wave. 


\section{Appendix 4. Simulations}

Table A4.1. A hypothetical far right electorate with anti-immigration concerns

\begin{tabular}{|l|l|l|r|l|l|l|l|}
\hline \multicolumn{2}{|l|}{ Far right } & & \multicolumn{2}{l|}{ Economic concerns } & \multicolumn{2}{l|}{ Cultural concerns } \\
\hline & Actual & percentage & & Actual & percentage & Actual & percentage \\
\hline No & 170 & $85 \%$ & No & 100 & $50 \%$ & 180 & $90 \%$ \\
\hline Yes & 30 & $15 \%$ & Yes & 100 & $50 \%$ & 20 & $10 \%$ \\
\hline
\end{tabular}

Table A4.2. A hypothetical far right electorate: tabulation of far right voters and antiimmigration concerns

\begin{tabular}{|l|l|l|l|l|l|}
\hline & $\begin{array}{l}\text { Economic } \\
\text { concerns }\end{array}$ & Cultural & \\
\hline Far right & No & Yes & & No & Yes \\
\hline No & $90(45 \%)$ & $80(40 \%)$ & & $160(80 \%)$ & $10(5 \%)$ \\
\hline Yes & $10(5 \%)$ & $20(10 \%)$ & & $20(10 \%)$ & $10(5 \%)$ \\
\hline
\end{tabular}

Table A4.3. A hypothetical far right electorate: regression results

\begin{tabular}{|c|c|c|c|c|c|}
\hline Source & SS & $d f$ & MS & Number of obs & 200 \\
\hline Model & 4.5 & 2 & 2.25 & Prob > F & 0.0000 \\
\hline Residual & 21 & 197 & .106598985 & R-squared & 0.1765 \\
\hline Total & 25.5 & 199 & .128140704 & Root MSE & .32649 \\
\hline farright & Coef. & Std. Err. & t & {$[95 \%$ Conf } & - Interval] \\
\hline econinsec & .2 & .0489742 & 4.08 & .1034189 & .2965811 \\
\hline cultinsec & .5 & .0816237 & 6.13 & .3390315 & .6609685 \\
\hline cons & $4.44 e-16$ & .0365033 & 0.00 & -.0719873 & .0719873 \\
\hline
\end{tabular}


Figure A4.1: Simulations of predicted country level far right party support for different hypothetical distributions of economic and cultural concerns by country
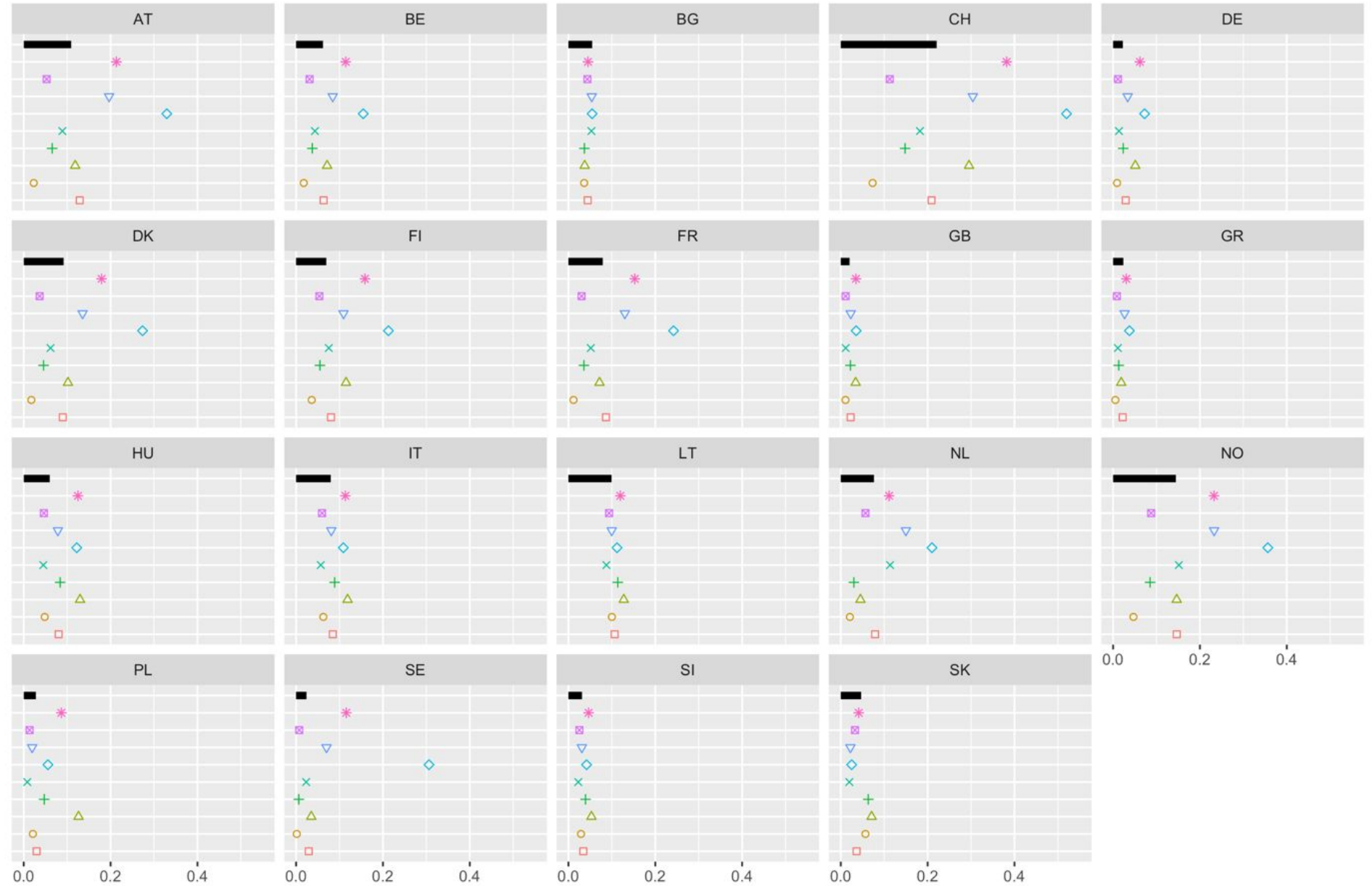
Actual values of both concerns
+ Economic concerns at 0 , cultural concerns at actual values $\nabla$ Economic concerns at 10, cultural concerns at actual values
- Economic concerns at 0 , cultural concerns at $0 \times$ Economic concerns at 10, cultural concerns at 0
$\bowtie$ Economic concerns at actual values, cultural concerns at 0
* Economic concerns at actual values, cultural concerns at 10

$\Delta$ Economic concerns at 0 , cultural concerns at $10 \diamond$ Economic concerns at 10 , cultural concerns at 10

Note: black line represents actual far right party votes in the country. 
Table A4.4. Estimates from country specific regressions

\begin{tabular}{|c|c|c|c|c|c|c|c|c|c|c|}
\hline Country & vright & econXcultX & econXculto & econXcult10 & econ0cultX & econ0culto & econ0cult10 & econ10cultX & econ10cult0 & econ10cult10 \\
\hline SK & $4.69 \%$ & $3.65 \%$ & $3.28 \%$ & $4.14 \%$ & $6.33 \%$ & $5.68 \%$ & $7.10 \%$ & $2.22 \%$ & $1.98 \%$ & $2.51 \%$ \\
\hline SI & $3.13 \%$ & $3.43 \%$ & $2.53 \%$ & $4.65 \%$ & $3.94 \%$ & $2.90 \%$ & $5.30 \%$ & $3.10 \%$ & $2.27 \%$ & $4.18 \%$ \\
\hline $\mathrm{SE}$ & $2.40 \%$ & $2.91 \%$ & $0.72 \%$ & $11.56 \%$ & $0.63 \%$ & $0.17 \%$ & $3.50 \%$ & $7.00 \%$ & $2.32 \%$ & $30.60 \%$ \\
\hline $\mathrm{NO}$ & $14.45 \%$ & $14.65 \%$ & $8.75 \%$ & $23.23 \%$ & $8.52 \%$ & $4.68 \%$ & $14.64 \%$ & $23.26 \%$ & $15.14 \%$ & $35.63 \%$ \\
\hline NL & $7.64 \%$ & $7.90 \%$ & $5.70 \%$ & $11.13 \%$ & $3.02 \%$ & $2.10 \%$ & $4.53 \%$ & $15.00 \%$ & $11.36 \%$ & $21.00 \%$ \\
\hline $\mathrm{HU}$ & $5.99 \%$ & $8.03 \%$ & $4.62 \%$ & $12.48 \%$ & $8.38 \%$ & $4.83 \%$ & $12.97 \%$ & $7.86 \%$ & $4.51 \%$ & $12.21 \%$ \\
\hline GR & $2.36 \%$ & $2.20 \%$ & $0.88 \%$ & $3.04 \%$ & $1.30 \%$ & $0.51 \%$ & $1.87 \%$ & $2.65 \%$ & $1.10 \%$ & $3.76 \%$ \\
\hline GB & $2.03 \%$ & $2.27 \%$ & $1.12 \%$ & $3.50 \%$ & $2.22 \%$ & $1.09 \%$ & $3.42 \%$ & $2.30 \%$ & $1.13 \%$ & $3.55 \%$ \\
\hline FR & $7.92 \%$ & $8.64 \%$ & $3.03 \%$ & $15.28 \%$ & $3.57 \%$ & $1.17 \%$ & $7.16 \%$ & $13.00 \%$ & $5.16 \%$ & $24.20 \%$ \\
\hline FI & $6.96 \%$ & $8.04 \%$ & $5.36 \%$ & $15.85 \%$ & $5.49 \%$ & $3.60 \%$ & $11.50 \%$ & $10.93 \%$ & $7.54 \%$ & $21.27 \%$ \\
\hline $\mathrm{BE}$ & $6.20 \%$ & $6.34 \%$ & $3.11 \%$ & $11.44 \%$ & $3.73 \%$ & $1.76 \%$ & $7.14 \%$ & $8.44 \%$ & $4.34 \%$ & $15.46 \%$ \\
\hline $\mathrm{AT}$ & $10.93 \%$ & $12.90 \%$ & $5.28 \%$ & $21.34 \%$ & $6.55 \%$ & $2.31 \%$ & $11.85 \%$ & $19.66 \%$ & $8.89 \%$ & $32.95 \%$ \\
\hline
\end{tabular}

Note: X captures keeping the distribution of values for that particular independent variable at its true value. For instance, econXcultX means that the distribution of values for economic and cultural concerns are kept as in the original true data. By contrast, econOcult10 means that all economic concerns for all individuals are set at 0 , whereas all cultural concerns for all individuals are kept at 10. The percentage show then capture the predicted national level support by aggregating all individual predicted probabilities given the coefficients and the distribution of values within the data. 


\section{Appendix 5. Results including PiS}

Table A5.1. Economic concerns and far right voters - with PiS

\begin{tabular}{|c|c|c|c|c|c|}
\hline \multirow[b]{2}{*}{ Economic concerns } & \multicolumn{5}{|c|}{ Far right voters and non-voters } \\
\hline & $\mathbf{0}$ & 1 & SUM & $\mathbf{0}$ & 1 \\
\hline $\mathbf{0}$ & 4219 & 222 & 4441 & $95.0 \%$ & $5.0 \%$ \\
\hline 1 & 4000 & 201 & 4201 & $95.2 \%$ & $4.8 \%$ \\
\hline 2 & 14932 & 719 & 15650 & $95.4 \%$ & $4.6 \%$ \\
\hline 3 & 19337 & 889 & 20226 & $95.6 \%$ & $4.4 \%$ \\
\hline 4 & 17142 & 959 & 18101 & $94.7 \%$ & $5.3 \%$ \\
\hline 5 & 33518 & 2613 & 36130 & $92.8 \%$ & $7.2 \%$ \\
\hline 6 & 12279 & 1128 & 13408 & $91.6 \%$ & $8.4 \%$ \\
\hline 7 & 11977 & 1417 & 13394 & $89.4 \%$ & $10.6 \%$ \\
\hline 8 & 8404 & 1149 & 9553 & $88.0 \%$ & $12.0 \%$ \\
\hline 9 & 4314 & 743 & 5057 & $85.3 \%$ & $14.7 \%$ \\
\hline 10 & 6131 & 1293 & 7424 & $82.6 \%$ & $17.4 \%$ \\
\hline TOTAL & 136252 & 11333 & 147585 & & \\
\hline
\end{tabular}

Table A5.2. Cultural concerns and far right voters - with PiS

\begin{tabular}{|c|c|c|c|c|c|}
\hline \multirow[b]{2}{*}{ Cultural concerns } & \multicolumn{4}{|c|}{ Far right voters and non-voters } & \multirow[b]{2}{*}{1} \\
\hline & $\mathbf{0}$ & 1 & SUM & Pe & \\
\hline $\mathbf{0}$ & 8975 & 393 & 9368 & $95.8 \%$ & $4.2 \%$ \\
\hline 1 & 7996 & 316 & 8312 & $96.2 \%$ & $3.8 \%$ \\
\hline 2 & 21586 & 1062 & 22648 & $95.3 \%$ & $4.7 \%$ \\
\hline 3 & 22914 & 1276 & 24190 & $94.7 \%$ & $5.3 \%$ \\
\hline 4 & 15892 & 1067 & 16958 & $93.7 \%$ & $6.3 \%$ \\
\hline 5 & 25167 & 2367 & 27535 & $91.4 \%$ & $8.6 \%$ \\
\hline 6 & 10069 & 1038 & 11107 & $90.7 \%$ & $9.3 \%$ \\
\hline 7 & 9348 & 1093 & 10442 & $89.5 \%$ & $10.5 \%$ \\
\hline 8 & 6601 & 1069 & 7669 & $86.1 \%$ & $13.9 \%$ \\
\hline 9 & 3427 & 590 & 4017 & $85.3 \%$ & $14.7 \%$ \\
\hline 10 & 4572 & 1075 & 5647 & $81.0 \%$ & $19.0 \%$ \\
\hline TOTAL & 136548 & 11346 & 147894 & & \\
\hline
\end{tabular}




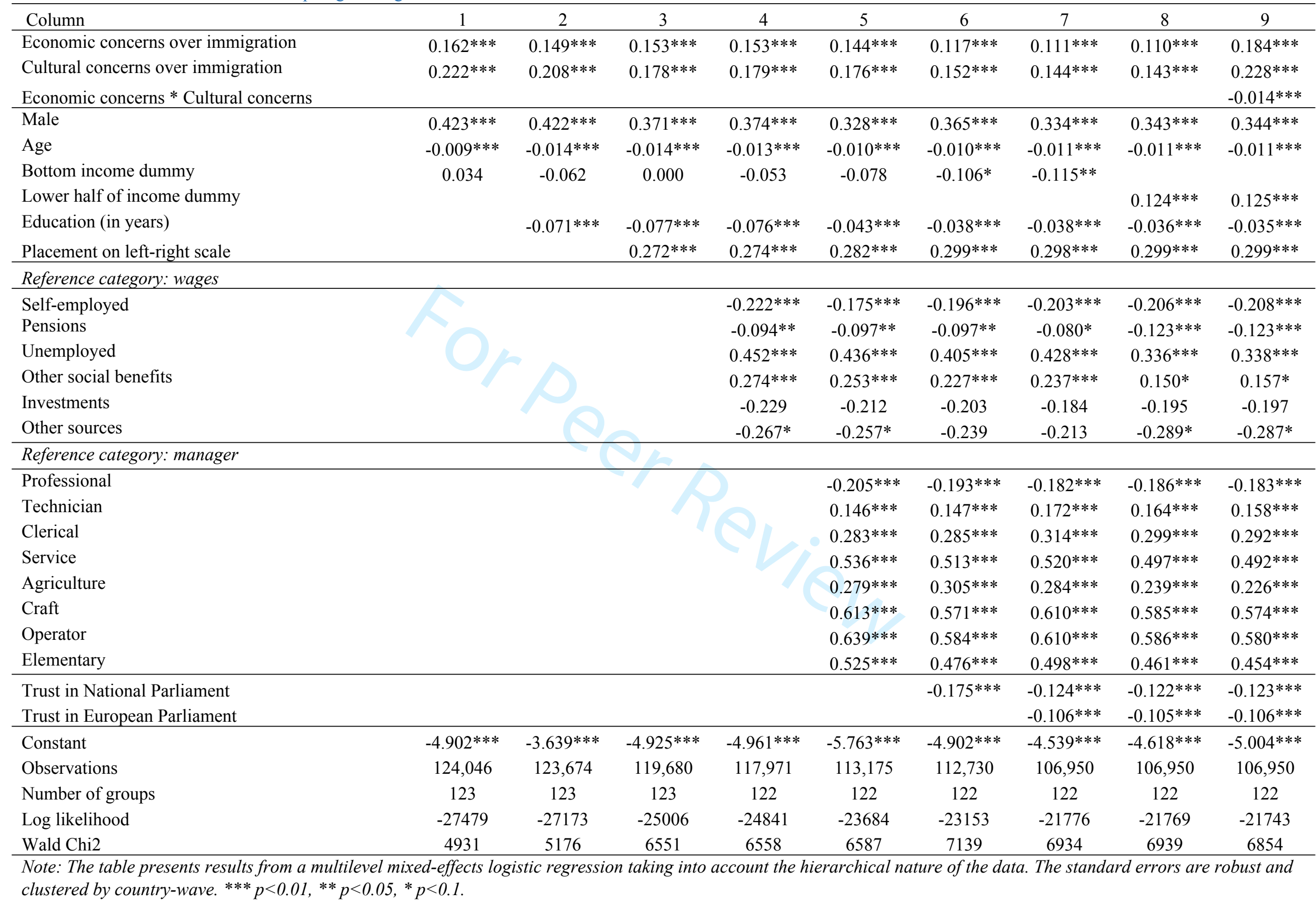


Figure A5.1: Predicted probabilities using column 8 of table A5.3

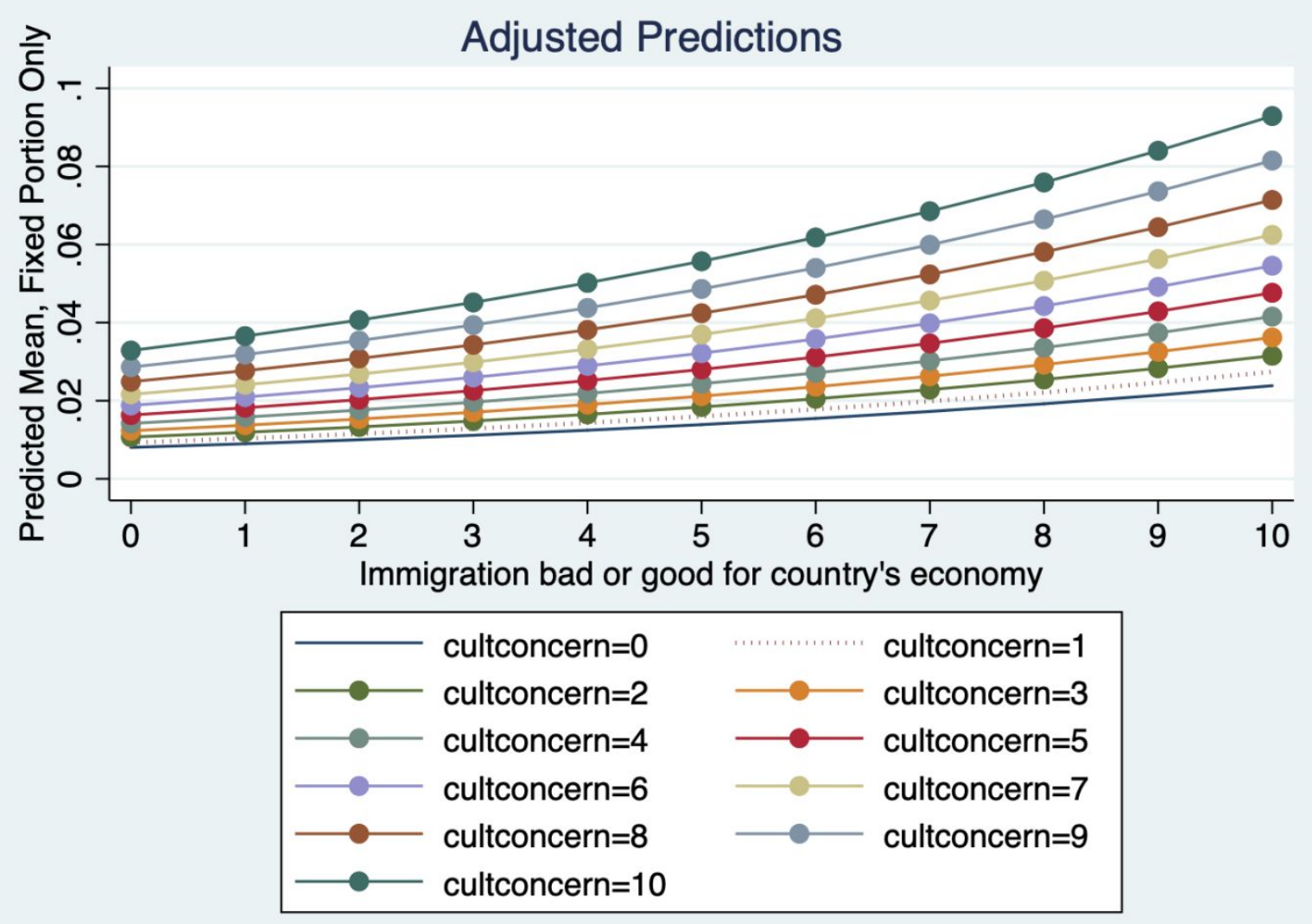

